\title{
Last Glacial Maximum-Holocene glacial and depositional history from sediment cores at Coulman High beneath the Ross Ice Shelf, Antarctica
}

\author{
by \\ Sanne Martha Maas
}

A thesis

submitted to Victoria University of Wellington in fulfilment of the requirements for the degree of Master of Science in Geology.

Antarctic Research Centre Victoria University of Wellington

August 2012 


\begin{abstract}
Sediment Cores collected from the shallow sub-sea floor beneath the Ross Ice Shelf at Coulman High have been analysed using sedimentological techniques to constrain the retreat history of the Last Glacial Maximum (LGM) ice sheet in the Ross Embayment, and to determine when the modern-day calving line location of the Ross Ice Shelf was established. A characteristic vertical succession of facies was identified in these cores, that can be linked to ice sheet and ice shelf extent in the Ross Embayment. The base of this succession consists of unconsolidated, clast rich muddy diamicts, and is interpreted to be deposited subglacially or in a grounding line proximal environment on account of a distinct provenance in the clast content which can only be attributed to subglacial transport from the Byrd Glacier $400 \mathrm{~km}$ to the south of the drill site. This is overlain by a mud with abundant clasts, similar in character to a granulated facies that has been documented previously in the Ross Sea, and is interpreted as being a characteristic grounding line lift-off facies in a sub-ice shelf setting. These glacial proximal facies pass upward into a mud, which comprises three distinctive units. i) Muds with sub-mm scale laminae resulting from traction currents occurring near the grounding line in a sub-ice shelf environment overlain by, ii) muds with sub-mm scale laminae and elevated biogenic content (diatoms and foraminifera) and sand/gravel clasts, interpreted as being deposited in open water conditions, passing up into a iii) bioturbated mud, interpreted as being deposited in sub-ice shelf environment, proximal to the calving line. The uppermost facies consists of a $\sim 20 \mathrm{~cm}$ thick diatom ooze with abundant clasts and pervasive bioturbation, indicative of a condensed section deposited during periodically open marine conditions. During post-LGM retreat of the ice sheet margin in western Ross Sea, and prior to the first open marine conditions at Coulman High, it is hypothesized that the grounding and calving line were in relative close proximity to each other. As the calving line became "pinned" in the Ross Island region, the grounding line likely continued its retreat toward its present day location. New corrected radiocarbon ages on the foraminifera shells in the interval of laminated muds with clasts, provide some of the first inorganic ages from the Ross Sea, and strengthen inferences from previous studies, that the first open marine conditions in the vicinity of Ross Island were $7,600{ }^{14} \mathrm{C}$ yr BP. While retreat of the calving line south of its present day position is implied during this period of mid-Holocene warmth prior to its re-advance, at present it is not possible to constrain the magnitude of retreat or attribute this to climate change rather than normal calving dynamics.
\end{abstract}




\section{Acknowledgements}

I would like to express gratitude to my supervisors, Tim Naish and Rob McKay. You guys have been invaluable during this time and I feel privileged to have studied under your supervision. Tim, despite the many conferences, IPCC meetings, and other important stuff, you were always only an email away. Thank you for taking me on as a student, it has been fun. Rob you have been great for getting familiar with the lab work, your door was always open, and you live for this 'stuff'. Thank you both for your support, also during the hard time when life became quite full on for me. All staff and students at the Antarctic Research Centre have been like a second family to me. Nick, you were always willing to listen and help me with whatever question I could throw at you, not just science related. Michelle, Nancy, Ruzica and Louise, thank you for being a listening ear. Alex, Darcy, Lionel, Huw, Warren, Peter, Dan, Gavin, Andrew, Brian, and all students, thanks.

This project would not have been possible without the funding from the ANDRILL program, it made it possible for me to visit the best continent in the world, and covered the costs for the analysis done on the cores. Without the crew out at Coulman High I would not have had any cores to study; Tamsin, JR, Richard (also great to have your support in Wellington), Tristan and the rest, thank you, I had an amazing first time experience on the ice. Thanks to Gary Wilson for being part of the field crew, and additionally for letting us use the laboratory at Otago University, with the help from Bob Dagg. Thanks to Gerhard Kuhn and the Alfred Wegener Institute for providing field equipment and doing lab analysis. Thanks to Antarctic New Zealand for field support. The Dominion Post helped me survive financially by granting me their Antarctic scholarship.

Lastly, thanks to my friends and family. My past and present awesome office mates, Denise, Laura, Karen, Kathi, Brook, Dick Davy, and Kolja. You have been seriously good company in cot521, I could not have asked for better ones. Fellow SGEES postgrads and staff, thanks for the discussions and brain storming, but also the entertaining times. Emily and Liam, Mike, non-uni friends and past and present staff at Fergs, thank you for the company outside the Cotton building, in the snow, on a bike or just in Wellywood.

Mamma, thank you so much for just being there for me in the background, even 
though you didn't always understand what I talked about, you have always believed in me. Pappa, I wish you were here to see me finish! Manon and Ruben, Julie and Tori, thank you for being there.

And Nick, you have been my rock and anchor, your love has helped me through not just the thesis, but throughout my time at university. Ik houd van je 


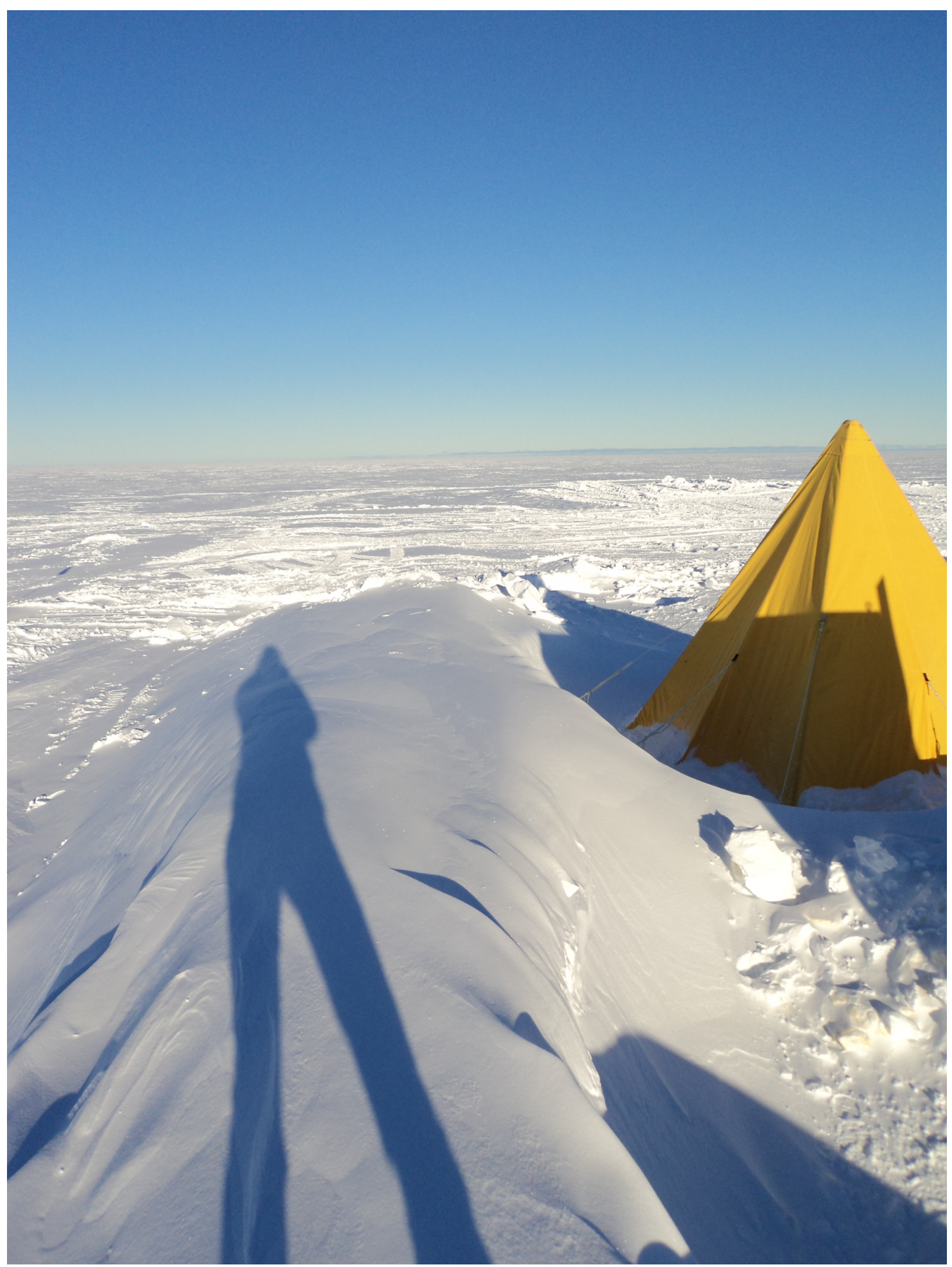




\section{Contents}

Abstract $\quad$ i

$\begin{array}{lll}\text { Acknowledgements } & \text { ii }\end{array}$

List of Figures vii

List of Tables $\quad$ ix

1 Introduction 1

1.1 Introduction . . . . . . . . . . . . . . . . . . . . 1

1.1.1 Thesis aims . . . . . . . . . . . . . . 2

1.1 .2 Thesis structure . . . . . . . . . . . . . . . 3

1.2 Modern day setting . . . . . . . . . . . . . . . . . . . . . 3

1.2.1 Ice shelves . . . . . . . . . . . . . . . . . . 3

1.2 .2 Ice flow . . . . . . . . . . . . . . . . . 8

1.2.3 Importance of the oceans with respect to the ice shelves . . . 9

2 Regional Setting $\quad 11$

2.1 Large scale tectonic setting . . . . . . . . . . . . . . . . . . . . 11

2.2 Geological setting . . . . . . . . . . . . . . . . . . . 13

2.3 Holocene climate . . . . . . . . . . . . . . . . . . . . 14

2.4 Ross Ice Shelf . . . . . . . . . . . . . . . . . . . . . . . . 16

2.4.1 Ross Sea during the last glacial advance . . . . . . . . . . . 16

2.4.2 Holocene retreat history of the Ross Ice Shelf . . . . . . . . . 17

2.5 Antarctic studies on Holocene sediment cores in different regions . . . 22

3 Methodology 24

3.1 Field work . . . . . . . . . . . . . . . . . . . . . . . . 24

3.1 .1 Core collection . . . . . . . . . . . . . . . . 24

3.1.2 Video imagery underneath the ice shelf . . . . . . . . . . 25

3.2 Laboratory work . . . . . . . . . . . . . . . . . . . . 26 
3.2.1 Core X-ray images . . . . . . . . . . . . . . . 26

3.2 .2 Physical properties . . . . . . . . . . . . . . . 26

3.2.3 Core description/lithostratigraphy . . . . . . . . . . . . 26

3.2 .4 Grain size analysis . . . . . . . . . . . . . . . 28

3.2.5 Petrology . . . . . . . . . . . . . . . . . . . 28

3.2.6 Diatom abundance . . . . . . . . . . . . . . . . . . . . 29

$3.2 .7{ }^{14} \mathrm{C}$ Chronology . . . . . . . . . . . . . . . . . . . . . . . 29

4 Results $\quad 32$

4.1 Sea floor and ice shelf imagery . . . . . . . . . . . . . . . . . 32

4.2 Core lithostratigraphy . . . . . . . . . . . . . . . 33

4.2 .1 Site 1 cores . . . . . . . . . . . . . . . . 33

4.2 .2 Site 2 cores . . . . . . . . . . . . . . . . 34

4.2 .3 Site 3 cores . . . . . . . . . . . . . . . . 35

4.2 .4 Site 4 cores . . . . . . . . . . . . . . . . . 36

4.3 Facies description . . . . . . . . . . . . . . . . . . . . . . 38

4.3.1 Massive diamict. Facies Dm. . . . . . . . . . . . . . 38

4.3.2 Mud with abundant clasts. Facies Mc. . . . . . . . . . . 39

4.3 .3 Mud . . . . . . . . . . . . . . . . . . . 39

4.3.4 Diatom ooze. Facies DO. . . . . . . . . . . . . . . . . . 40

4.4 Chronology . . . . . . . . . . . . . . . . . . . . 46

$\begin{array}{lll}5 & \text { Discussion } & 49\end{array}$

5.1 Depositional model . . . . . . . . . . . . . . . . . . . . 49

5.1 .1 Subglacial . . . . . . . . . . . . . . . . . 49

5.1 .2 Sub-ice shelf, proximal to the grounding line . . . . . . . . . 51

5.1 .3 Sub-ice shelf . . . . . . . . . . . . . . . . . . 52

5.1 .4 Open water . . . . . . . . . . . . . . . . . 54

5.2 Chronology of post LGM glacial retreat in the Ross Embayment . . . 55

6 Conclusions and future work $\quad 62$

$\begin{array}{ll}\text { References } & 64\end{array}$

$\begin{array}{ll}\text { A Field Methods } & 77\end{array}$

$\begin{array}{lr}\text { B Data from all cores } & 81\end{array}$ 


\section{List of Figures}

1.1 The Antarctic continent . . . . . . . . . . . . . . . 2

1.2 Schematic map of ANDRILL field season 2010-2011 . . . . . . . . . . 4

1.3 Map of Ross Ice Shelf with recent icebergs lined out . . . . . . . . . . 6

1.4 Ice flow of the Ross Ice Shelf . . . . . . . . . . . . . . . . . . . 8

1.5 Schematic diagram of the circulation and water mass formation at the Ross Ice Shelf ice front . . . . . . . . . . . . . . . . . 10

2.1 Ross Sea tectonics map . . . . . . . . . . . . . . . . . . 12

2.2 TAM provenance map . . . . . . . . . . . . . . . . . . . . 14

$2.3 \delta^{18} \mathrm{O}$ curve from TALDICE record . . . . . . . . . . . . . . 16

2.4 Schematic reconstructions of the different paleoice-flow models of the WAIS and EAIS into the Ross Ice Shelf . . . . . . . . . . . . . . . 18

2.5 Map of Ross Embayment with the retreat of the grounded ice sheet and Ross Ice Shelf since LGM . . . . . . . . . . . . . . . . . . 19

2.6 Two scenarios for the deglaciation of the Ross Sea . . . . . . . . . . . 20

3.1 Site locations during the ANDRILL site survey . . . . . . . . . . 25

3.2 Classification scheme for sediments that are a mixture of biogenic, volcaniclastic and terrigenous clastic particles . . . . . . . . . . 27

3.3 Classification scheme for terrigenous sediments lacking gravel component . . . . . . . . . . . . . . . . . . . . . . . . . . 28

3.4 Samples taken from CHGC-07 for foraminifera . . . . . . . . . . . . 31

4.1 Image from the sea floor . . . . . . . . . . . . . . . . . . . . 32

4.2 Composite figure of cores from each site . . . . . . . . . . . . . 37

4.3 Stratigraphic column from CHGC-08 . . . . . . . . . . . . . . . . 41

4.4 Photographs of diatoms in CHGC-08 . . . . . . . . . . . . . . . 42

4.5 Pie charts on petrology data from CHGC-08 . . . . . . . . . . . . . . 43

4.6 Photographs of grains in CHGC-08 . . . . . . . . . . . . . . . . . 44

4.7 Composite log of CHGC-08 . . . . . . . . . . . . . . . 45 
$4.8{ }^{14} \mathrm{C}$ Chronology on bulk sediment . . . . . . . . . . . . . . . . . 48

5.1 Grain size distribution of CHGC-08 . . . . . . . . . . . . . . . 52

5.2 CHGC-11 X-ray image zoomed in on laminations . . . . . . . . . . . 53

5.3 Cartoon depicting the retreat of the grounded ice at Coulman High . 56

5.4 Map of cores site and retreat of the ice shelf . . . . . . . . . . . . 61

A.1 Sketch to illustrate the thickness of the ice shelf, distance from calving line, and the water column depth. . . . . . . . . . . . 79

B.1 Stratigraphic $\log$ for CHGC-05 . . . . . . . . . . . . . . 82

B.2 Stratigraphic log for CHGC-07 . . . . . . . . . . . . . . . . 83

B.3 Stratigraphic $\log$ for CHGC-11 . . . . . . . . . . . . . . . . . 84

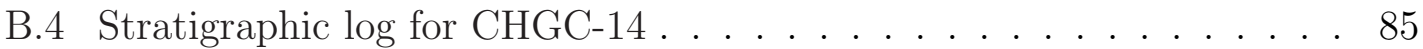

B.5 Stratigraphic $\log$ for CHGC-17 . . . . . . . . . . . . . 86

B.6 Stratigraphic log for CHGC-22 . . . . . . . . . . . . . . . . . 87

B.7 Stratigraphic log for CHGC-23 . . . . . . . . . . . . . . . . . 88

B.8 Physical Properties from CHGC-05 . . . . . . . . . . . . . . . . 89

B.9 Physical Properties from CHGC-11 . . . . . . . . . . . . . . . . 90

B.10 Physical Properties from CHGC-17 . . . . . . . . . . . . . . . 91

B.11 Physical Properties from CHGC-22 . . . . . . . . . . . . . . . 92

B.12 Physical Properties from CHGC-14 . . . . . . . . . . . . . . . 93

B.13 Grainsize on CHGC-08 . . . . . . . . . . . . . . . . . . 98

B.14 Grainsize on CHGC-08 $(<150 \mu \mathrm{m}) \quad \ldots . . . . . .99$

B.15 Sortable silt data from CHGC-08 . . . . . . . . . . . . . . . . . 104 


\section{List of Tables}

3.1 The four sites at Coulman High used for the sedimentological data recovery. . . . . . . . . . . . . . . . . . 24

3.2 Classification scheme for terrigenous sediments containing a gravel component . . . . . . . . . . . . . . . . . . 27

$4.1{ }^{14} \mathrm{C}$ Chronology on bulk sediment . . . . . . . . . . . . . . . 47

4.2 Radiocarbon ages on foraminifera . . . . . . . . . . . . . 47

A.1 Information on the ANDRILL site survey activities . . . . . . . . . 80

B.1 Physical property data from CHGC-08 . . . . . . . . . . . . . 94

B.2 Physical property data from CHGC-14 . . . . . . . . . . . . . . 95

B.3 Physical property data from CHGC-23 . . . . . . . . . . . . . 96

B.4 Diatom counts . . . . . . . . . . . . . . . . . . 97

B.5 Grain size results from CHGC-08 . . . . . . . . . . . . . . . 100

B.6 Grain size results from CHGC-08 continued . . . . . . . . . . . . . . 101

B.7 Grain size results from CHGC-08 continued . . . . . . . . . . . . . 102

B.8 Grain size results from CHGC-08 continued . . . . . . . . . . . . . 103

B.9 Petrology counts for CHGC-08 . . . . . . . . . . . . . . . . . 104 


\section{Chapter 1}

\section{Introduction}

\subsection{Introduction}

The Antarctic continent is covered by two large ice sheets, the East and West Antarctic Ice Sheets, of which the West Antarctic Ice Sheet is mainly grounded below sea level and is partially encompassed by several ice shelves that are thought to provide a buttress restricting the flow of outlet glaciers that drain the grounded ice sheet. This study investigates cores collected underneath the largest ice shelf, Ross Ice Shelf, on the eastern site of Ross Island (Figure 1.1). To better comprehend the response of the Ross Ice Shelf in the present day changing climate, an understanding of how the Ross Ice Shelf reacted to past climate change is necessary. In particular, the style, timing and rate of retreat of the grounded ice sheet in the Ross Embayment during the last glacial termination is key in understanding the forcing that may lead to future retreat of the West Antarctic Ice Sheet.

During the Antarctic Geological Drilling (ANDRILL) site survey of the 2010-2011 austral season, four holes were drilled through the Ross Ice Shelf at Coulman High with the aim of collecting oceanographic and geologic data (Figure 1.2). The Coulman High drill sites are located between 10 and $20 \mathrm{~km}$ south of the present day Ross Ice Shelf calving line, and $60 \mathrm{~km}$ east of Ross Island (Figure 1.2). The drill site is located within an area affected by calving of large tabular icebergs. The last calving event occurred in 2002 when the C-19 iceberg calved off (Ferrigno et al., 2008), exposing most of the drill sites to open ocean conditions, and the ice shelf has since extended further north at $2 \mathrm{md}^{-1}$ (Fischbein, 2010). The Coulman High

drill cores studied in this thesis provide a record of the retreat history of the Ross Ice Shelf including the timing of the retreat of the Last Glacial Maximum (LGM) grounding line, the establishment of modern day calving position, and investigate 


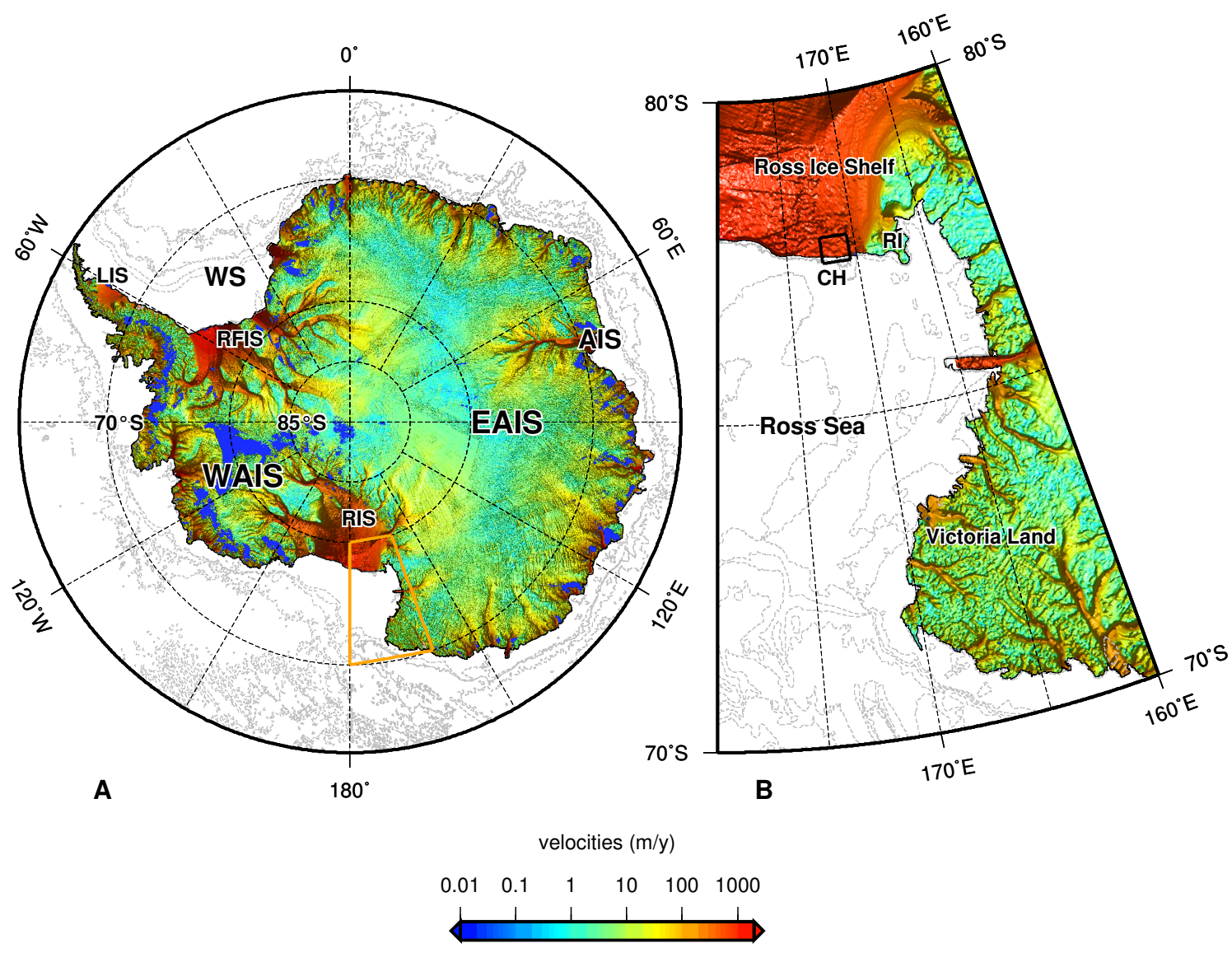

Figure 1.1: The Antarctic continent, showing ice cover coloured by surface velocities (Rignot et al., 2011). RIS=Ross Ice Shelf, EAIS=East Antarctic Ice Sheet, WAIS=West Antarctic Ice Sheet, AIS=Amery Ice Shelf, LIS=Larsen Ice Shelf, RFIS=Ronne-Filchner Ice Shelf, WS=Weddell Sea. The orange box in $A$ shows the outline of $B$. The black box in $B$ represents the location of the Coulman High site survey, $\mathrm{CH}=$ Coulman High, $\mathrm{RI}=$ Ross Island.

the role that Ross Island may have played in acting as a pinning point that helped stabilise the Ross Ice Shelf during the Holocene.

\subsubsection{Thesis aims}

This thesis presents the analysis and interpretation of gravity cores, which sample the shallow sub-sea floor from four sites currently located beneath the Ross Ice Shelf. The aims of this thesis are to:

- Refine existing sedimentation models for glacimarine sediments deposited during the post LGM ice sheet retreat in Ross Sea by using sedimentological, geochemical, geophysical, petrographic and paleontological analysis to distinguish past periods of marine, sub-ice shelf and sub-glacial depositional environments at this calving line proximal site. 
- Develop a retreat history of the grounded ice sheet in the Ross Embayment and the development of the modern day ice shelf calving line position of the Ross Ice Shelf during the Holocene.

\subsubsection{Thesis structure}

This thesis is structured as follows:

- Chapter 1 outlines the aims of the research and provides an overview of the modern processes influencing the Ross Ice Shelf.

- Chapter 2 covers the large scale tectonic and geological setting of Ross Embayment, including basin structure and Transantarctic Mountain geology that provides a background to sediment transport pathways and provenance. It also summarises the understanding of glacial history of the Ross Embayment from the LGM to present day.

- Chapter 3 discusses data acquisition and methodologies.

- Chapter 4 presents the results from the sedimentological, physical properties, petrology, diatom and radiocarbon analyses.

- Chapter 5 discusses the results and their implications, in particular the behaviour of the grounded ice sheet/Ross Ice Shelf in the Western Ross Sea since the LGM.

\section{$1.2 \quad$ Modern day setting}

\subsubsection{Ice shelves}

The Ross Ice Shelf, encompassing an area of 560,000 $\mathrm{km}^{2}$, is the world's largest ice shelf (Figure 1.1). Two thirds of the ice shelf is sustained by ice streams that drain the West Antarctic Ice Sheet (WAIS) and the remaining third by glaciers that discharge from the East Antarctic Ice Sheet (EAIS), through the Transantarctic Mountains (TAM) (Fahnestock et al., 2000). The EAIS is the more stable of the two ice sheets, as it is mostly grounded above sea level, and a loss of ice shelves is thought to not have a significant influence on the mass balance of the EAIS (Thomas, 1979). However, the WAIS is largely grounded below sea level, and Mercer (1978) proposed the ice shelves play a vital role in the stability of the WAIS, and that the retreat of ice shelves would be the first sign of the effects of a warming climate (Rignot et al., 2004).

Without the existence of the Ross Ice Shelf, and other major ice shelves surrounding 

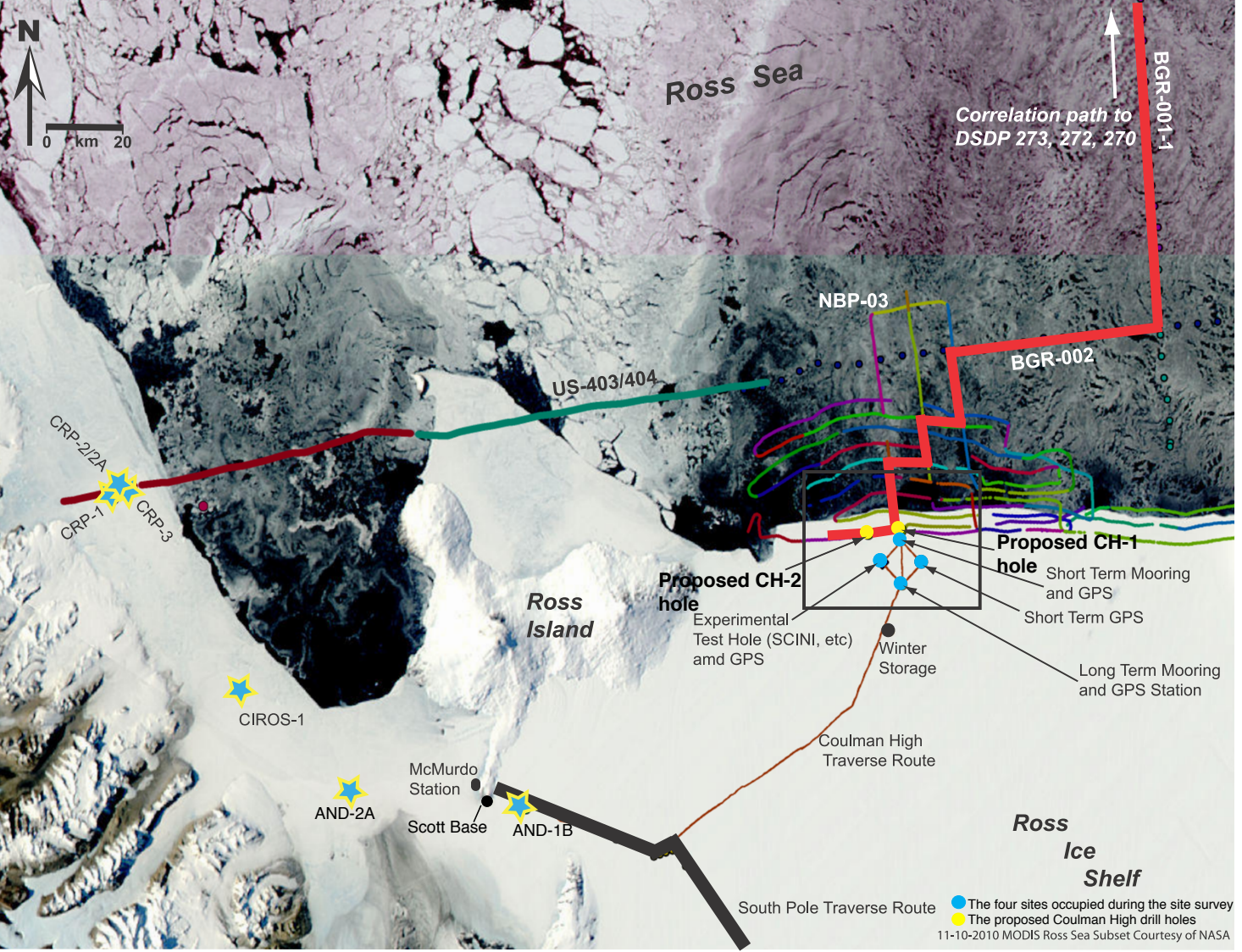

Figure 1.2: Schematic map of ANDRILL field area. The four different sites (blue circles) were used for oceanographic and sedimentological data recovery. Yellow circles represent the proposed Coulman High drill holes. Previous drill holes are depicted by stars. Image courtesy of Richard Levy, ANDRILL.

the ice sheet, it is possible that the WAIS will collapse rapidly. The bedrock under the WAIS offers few stabilising points for the grounding line, i.e. there are few steps present in the bedrock. The presence of the ice shelves helps to not only thicken the ice sheet, but they essentially 'buttress' the ice sheet. They exert a back pressure on the grounding line, which slows down the ice flow rate of the ice sheet (Thomas, 1979). Additionally, retreat of the grounding line is controlled by the nature of the bed topography. If the bedrock slopes downwards to the interior of the ice sheet (i.e. in case of West Antarctica), a steady state of the ice sheet cannot be reached and the retreat of the grounding line accelerates, and total collapse of the ice sheet is likely to follow (Thomas, 1979; Schoof, 2007).

The presence of pinning points in the Ross Embayment plays an important role in the stability of the Ross Ice Shelf and ultimately the stability of the WAIS, allowing ice shelves to thicken and strengthen (Thomas and Bentley, 1978; Alley et al., 
1989). Lindenberg Island is situated in the northern part of the previously extensive Larsen-B Ice Shelf. This island has acted as a pinning point and delayed the retreat of the ice shelf (Rott et al., 1998). It is likely that Ross Island plays a similar role for the Ross Ice Shelf.

While the mean annual $-5^{\circ} \mathrm{C}$ isotherm was previously considered to govern the stability of an ice shelf (Vaughan and Doake, 1996), it now seems that sub-shelf ocean temperature plays a more important role (Domack et al., 2005; Pritchard et al., 2012). Sediment cores collected in the area where the Larsen B Ice Shelf used to be on the Antarctic Peninsula, suggest that the ice shelf was thinning throughout the Holocene due the warming of the ocean water, and that the more recent rise of atmospheric temperatures in combination with the already thinned ice shelf, caused the collapse of the ice shelf in March 2002 (Domack et al., 2005). Following the collapse of the Larsen B Ice Shelf, Landsat imagery indicated that four glaciers that were buttressed by the Larsen B Ice Shelf, sped up by two- to six-fold for a period of three years (Scambos et al., 2004).

Continuous Antarctic atmospheric temperature measurements began in 1957, and show that the continent as a whole has warmed since (Jacka and Budd, 1998). Warming of the continent is strongest on the Antarctic Peninsula, with $+1.1^{\circ} \mathrm{C}$ per decade (Steig et al., 2009), and this warming of the Peninsula extends into the WAIS. However, Bertler et al. (2004) showed that the Ross Sea region has undergone regional cooling which is linked to the El Niño Southern Oscillation (ENSO) and the Southern Annular Mode (SAM). When it is a La Niña event, the Amundsen Sea Low is positioned at the edge of the Ross Sea. However, during a positive SAM in combination with El Niño, the Amundsen Sea Low is located at $\sim 140^{\circ} \mathrm{W}$, and this causes cool air to flow from the West Antarctic continent to flow onto the Ross Ice Shelf (Cullather et al., 1996; Bertler et al., 2004). The positive trend of the SAM is the poleward migration of the westerly winds (e.g. Fyfe et al., 1999) as well as the depletion in ozone over the pole and to increased greenhouse gasses (e.g. Thompson and Solomon, 2002; Arblaster and Meehl, 2006). The Ross Sea region is kept cooler under conditions of a positive SAM (Bertler et al., 2004). 


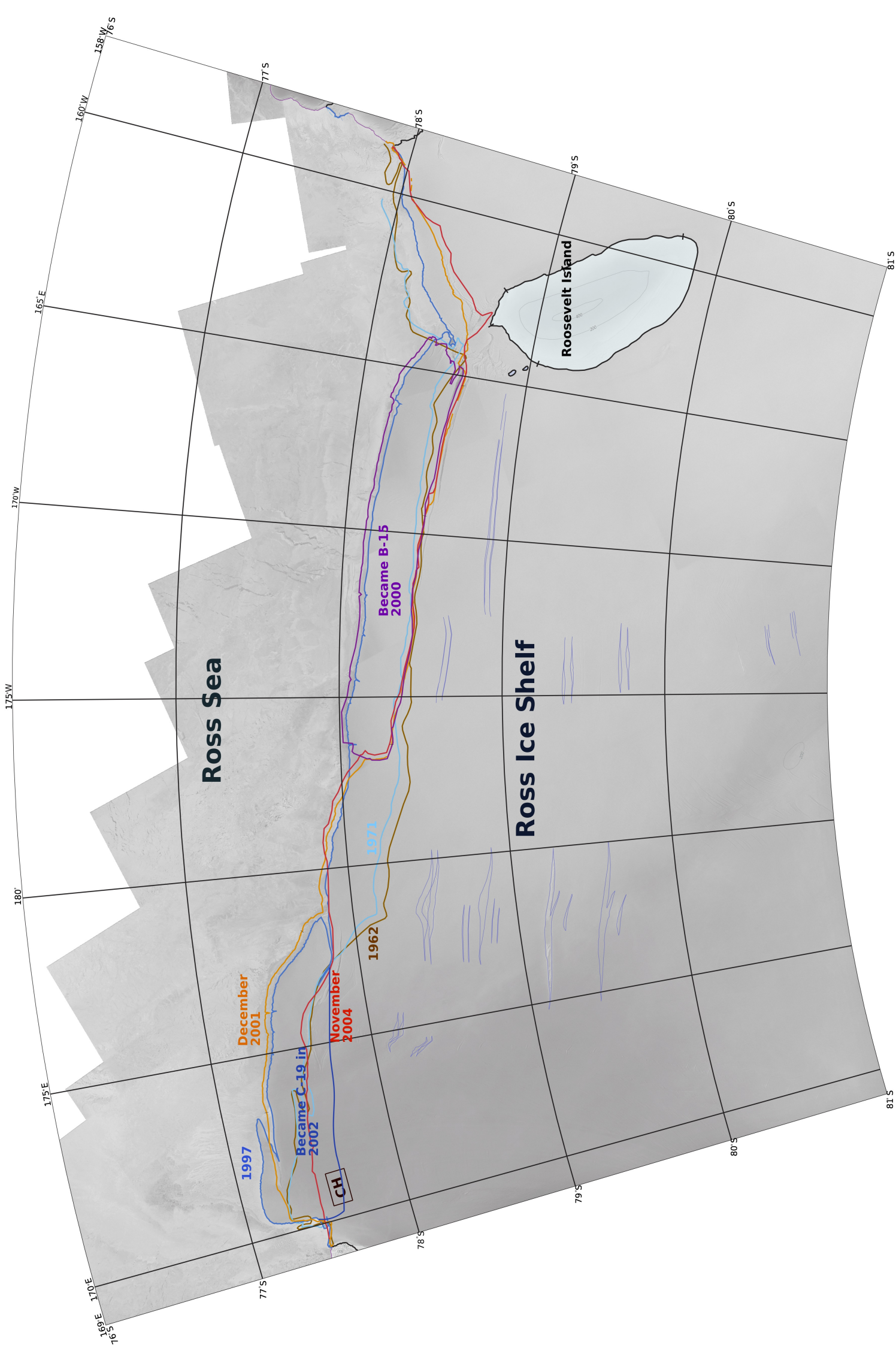

苂

崩

.

$\stackrel{8}{\$} \infty$

㝳営

ర

:

10

ติ

so $\vec{\sigma} \cdot \vec{c}$

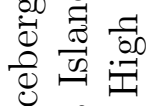

$\because$ की

ب થी

च

过

की จำ

ฯ $\exists=$

풍

$\frac{\pi}{n}$

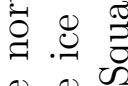

东

岁出

के प्र क

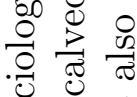

क

羊

- 4 . 8

웡 용

త్రీن

๘ี

梁

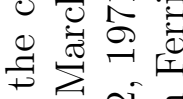

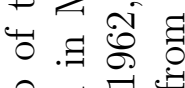

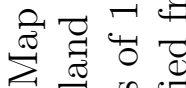

常

ช.

范苟.

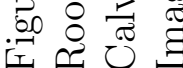




\section{Calving}

The typical behaviour of an ice shelf is to move seaward, pushed by the flow of the grounded ice sheet in the direction of the ocean and driven by its thickness gradient which in turn controls flux at the grounding line. On the whole, the ice shelf speeds up seaward as its flow becomes less constricted. As the ice shelf keeps extending, it will reach an unstable position and stresses in the ice will cause the calving of icebergs (Ferrigno et al., 2008). The modern day calving of large tabular icebergs originates from existing rifts that are parallel to the calving front, and cut through the ice shelf (Figure 1.4; Lazzara et al., 2008). These rifts can be several hundreds of kilometres long, cutting through the entire shelf and filling with ocean water, sea ice and windblown snow. The rifts can form by surface crevasses propagating downwards, by bottom crevasses that propagate upwards, or lateral propagation of a crack initiating near the edge of the shelf (Lazzara et al., 2008).

The discrimination between normal calving events and climate-induced retreat of ice shelves is difficult, but in general if an ice shelf becomes unstable, its retreat will increase via small annual calving events, without a significant re-advance of the ice shelf (Vaughan and Doake, 1996). The front of the Ross Ice Shelf is currently stable, and the calving of tabular icebergs, such as C-19 at Coulman High, has likely occurred throughout much of the Holocene, i.e. since the stabilisation of the calving line in the vicinity of Ross Island. The Ross Ice Shelf advances as a whole approximately $1 \mathrm{~km} / \mathrm{y}$ near the ice front (Paterson, 1994), and as a consequence is expected to calve on average at the same rate, albeit in calving events separated by several decades (Figure 1.3).

Recent calving events on the Ross Ice Shelf have been captured by satellite imagery. In March 2002, a large iceberg (C-19) calved off the Ross Ice Shelf near Ross Island, and is the most recent natural calving event (Figure 1.3; Lazzara et al., 2008). Horgan et al. (2011) suggest that such calving events influence the basal melt rate of the Ross Ice Shelf. During periods of no calving, the surface elevation of the ice shelf thins as it approaches the front. After a calving event, the thickness of the shelf reverts back to an equilibrium thickness of a shelf that is flowing freely, and hence has a lower melt rate (Horgan et al., 2011). 


\subsubsection{Ice flow}

Satellite imagery is a useful tool to determine the flow of the Antarctic Ice Sheets. Using a composite Advanced Very High Resolution Radiometer (AVHRR), Fahnestock et al. (2000) were able to identify the flow and subtle topographic features of the Ross Ice Shelf (Figure 1.4). By depicting the traces seen on the ice shelf it is

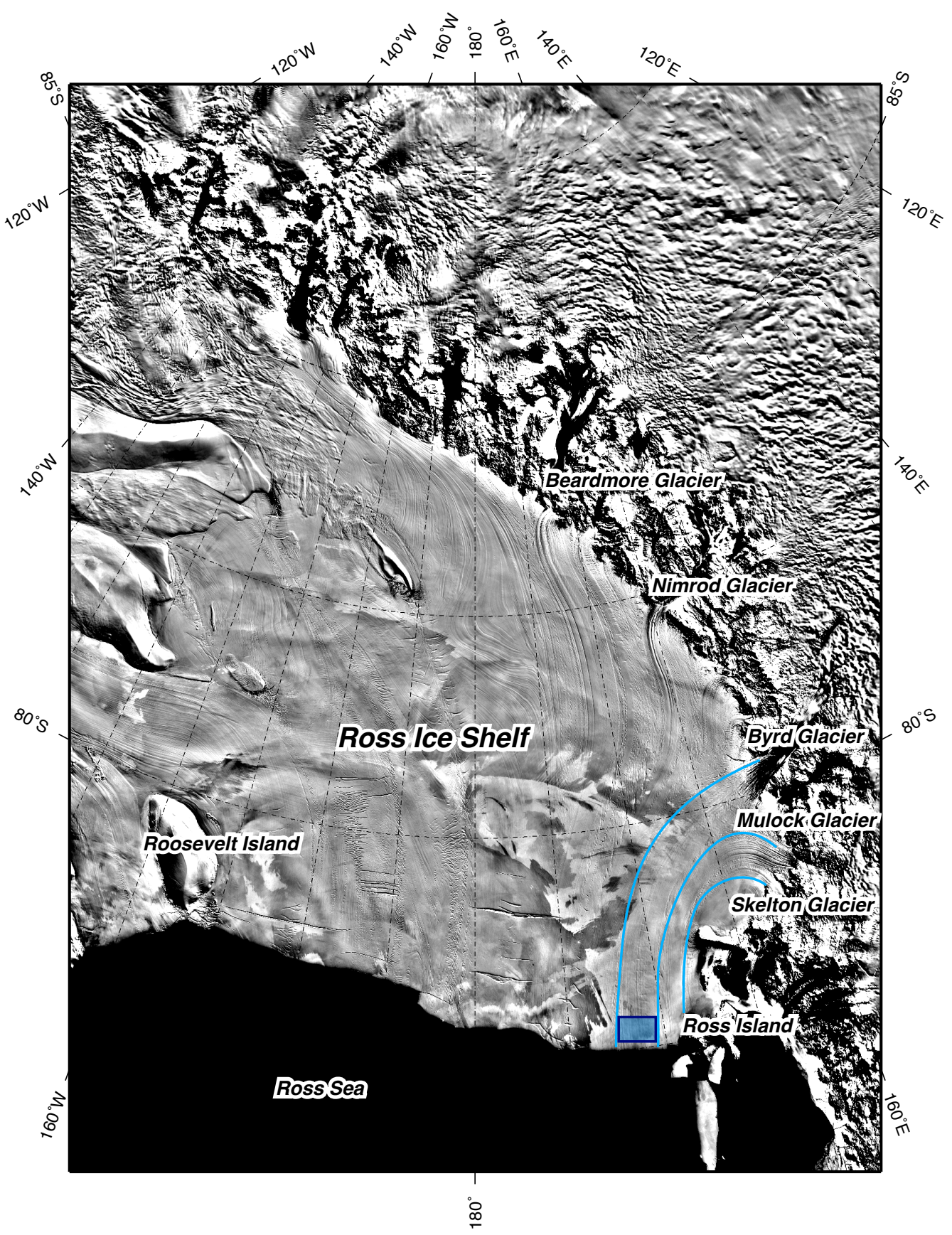

Figure 1.4: Satellite image of the Ross Ice Shelf (Haran et al., 2005). The dark blue square represents the location of the Coulman High site survey. The flow lines from the Byrd and the Mulock Glacier are highlighted by the light blue lines. 
possible to detect the origin of the ice (i.e. from which glacier or ice stream the ice flowed from). The pattern of modern day ice flow in western Ross Sea depicted by AVHRR indicates that the study area in this thesis is mainly fed by ice from Byrd Glacier, and smaller glaciers further north (Figure 1.4).

The current velocity of the ice shelf near the calving line at the study site is 2 $\mathrm{m} /$ day, as measured by continuous GPS monitoring during the ANDRILL site survey in the austral summer of 2010-2011 (Fischbein, 2010). The present-day position of the calving line lies at approximately $77^{\circ}$ south, and the grounding line is situated along the Siple Coast (Shabtaie and Bentley, 1987).

\subsubsection{Importance of the oceans with respect to the ice shelves}

The importance of the ice shelves around the Antarctic continent goes beyond their role as buttresses to the ice sheet. The impact the ice shelves have on the ocean is critical since their interaction contributes to the formation of Antarctic bottom water (Orsi et al., 1999). The melting and freezing of the water underneath the ice shelf modifies the water density and temperature. Super cold water underneath ice shelves, formed by the melting and refreezing, is called Ice Shelf Water (ISW). In the Ross Sea, ISW is defined by water temperatures colder than $-1.9^{\circ} \mathrm{C}$ and a salinity of $\sim 34 \mathrm{psu}$ (Jacobs, 2004). The dense water mass that is formed by the formation of sea ice is called High Salinity Shelf Water (HSSW) and can mix with the ISW to flow to the edge of the continental shelf and mixes with the Circumpolar Deep Water (CDW) to form Antarctic Bottom Water (AABW; Figure 1.5; Smethie et al., 2005). The stability and mass balance of the ice shelves is strongly controlled by marine and atmospheric influences, such as atmospheric and ocean temperature, precipitation, and sea level change (Holland et al., 2008; Pollard and DeConto, 2009).

It has been noted that since 1994 the ice shelves in Pine Island Bay have been thinning due to the presence of relatively warm water (e.g. Jacobs et al., 1996; Shepherd et al., 2001; Rignot and Jacobs, 2002; Shepherd et al., 2004). The source of the warm water has recently been identified to be CDW (Jacobs et al., 2011). Due to oceanographic processes, the warm CDW (with maximum temperatures $+1.2^{\circ} \mathrm{C}$; Jacobs, 2004), moves onto the continental shelf, and since this water mass is warmer than the ISW and HSSW, it may cause relatively rapid basal melting of an ice shelve (Jacobs et al., 2011). Pritchard et al. (2012) states that the fastest thinning of the marine based of an ice sheet, exists in places where the basal melt rates are elevated because warm ocean water is able to reach ice shelves and the grounding zone 


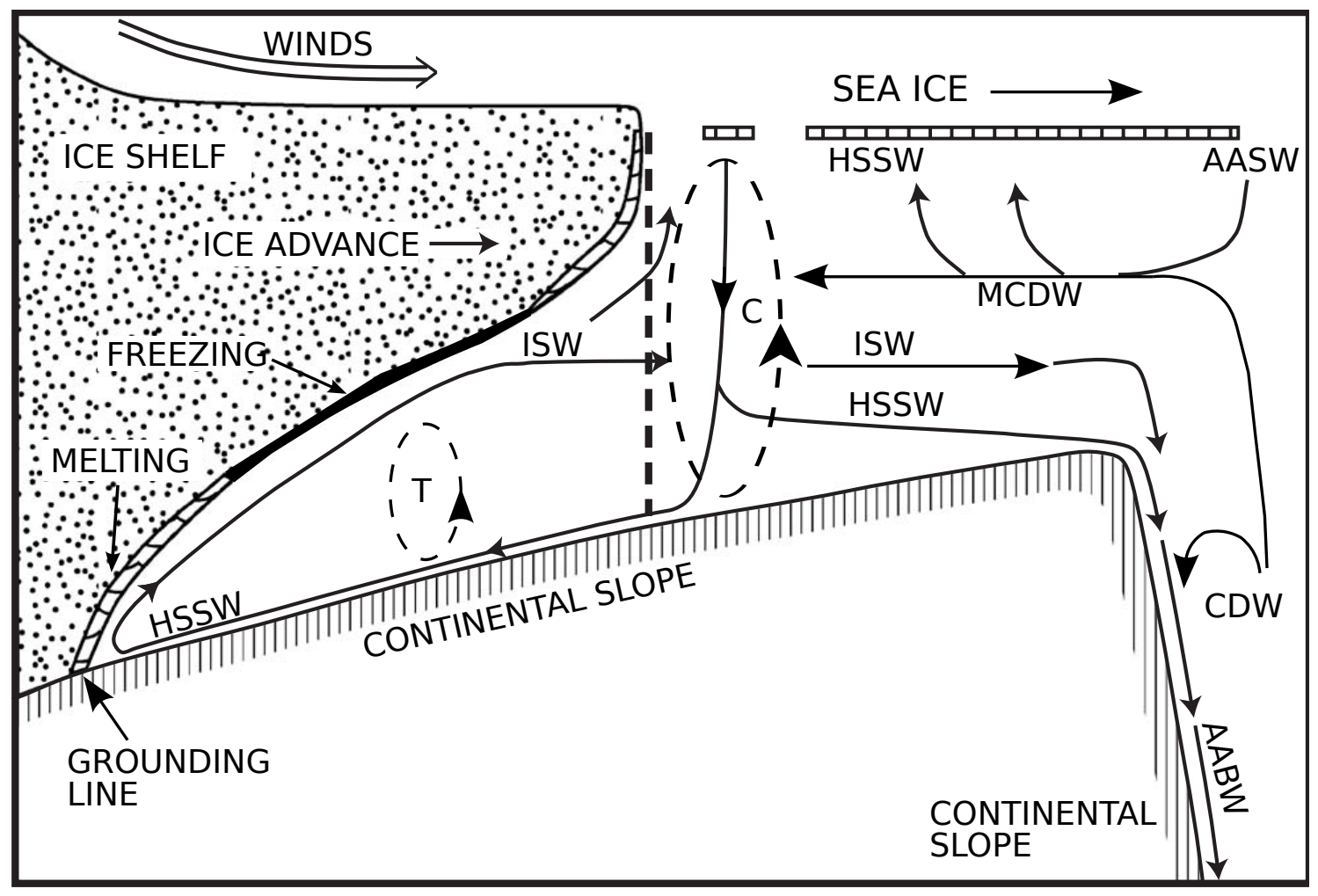

Figure 1.5: Schematic diagram of the circulation and water mass formation at the Ross Ice Shelf ice front. AASW = Antarctic Surface Water, CDW = Circumpolar Deep Water, MCDW = Modified Circumpolar Deep Water, ISW = Ice Shelf Water, HSSW = High Salinity Shelf Water, AABW = Antarctic Bottom Water. Dashed circulation cell labelled $\mathrm{C}=$ winter convective mixing, dashed circulation cell labelled $\mathrm{T}=$ tidal mixing. Image modified from Smethie et al. (2005).

via deep ocean troughs. Rignot and Jacobs (2002) emphasise that the area near the grounding line, where the glacier starts to float, is highly sensitive to increased ocean temperatures. For every $0.1^{\circ} \mathrm{C}$ of warming ocean water, the ice shelf melting rate increases by 1 metre per year (Figure 1.5; Rignot and Jacobs, 2002). 


\section{Chapter 2}

\section{Regional Setting}

\subsection{Large scale tectonic setting}

Antarctica can be divided into three main tectonic parts, the East Antarctica craton, the West Antarctic Rift System (WARS) and the Transantarctic Mountains (TAM) (Watson et al., 2006). When reconstructing Gondwana, East Antarctica has been treated as a stable block, whereas West Antarctica is an archipelago which has moved relative to East Antarctica (Dalziel and Elliot, 1982). The WARS is among the largest rift systems on Earth (Behrendt et al., 1991) and transects the Antarctic continent. The TAM marks the western Ross Sea and the western boundary of the WARS, and is the largest non-collisional mountain range in the world (Uri et al., 1997). The mountain belt is a division between the East Antarctic craton and the WARS (Watson et al., 2006).

Due to the existence of a continental-scale ice sheet for the last $34 \mathrm{Ma}$, only limited sedimentary rock successions are exposed which has led to a fragmented history of the climatic and tectonic evolution of Antarctica during the Cenozoic (Barrett, 2008). Both the Cenozoic Investigations of the Ross Sea-1 (CIROS-1) and the Cape Roberts Projects have given a more detailed insight into the geological evolution of Antarctica and the ice sheet during the last 34 Ma (Barrett, 1996; Naish et al., 2001). Numerous seismic reflection surveys have been undertaken in the Ross Embayment that have led to several seismic frameworks and interpretations for the evolution of the Victoria Land Basin (e.g. Hall et al., 2007; Cooper et al., 2008; Fielding et al., 2008).

The Ross Sea is part of the WARS and contains three major north-south trending sedimentary basins; the Victoria Land Basin, the Central Trough and the Eastern Basin (Cooper et al., 1987). The three basins are separated by two basements highs, 


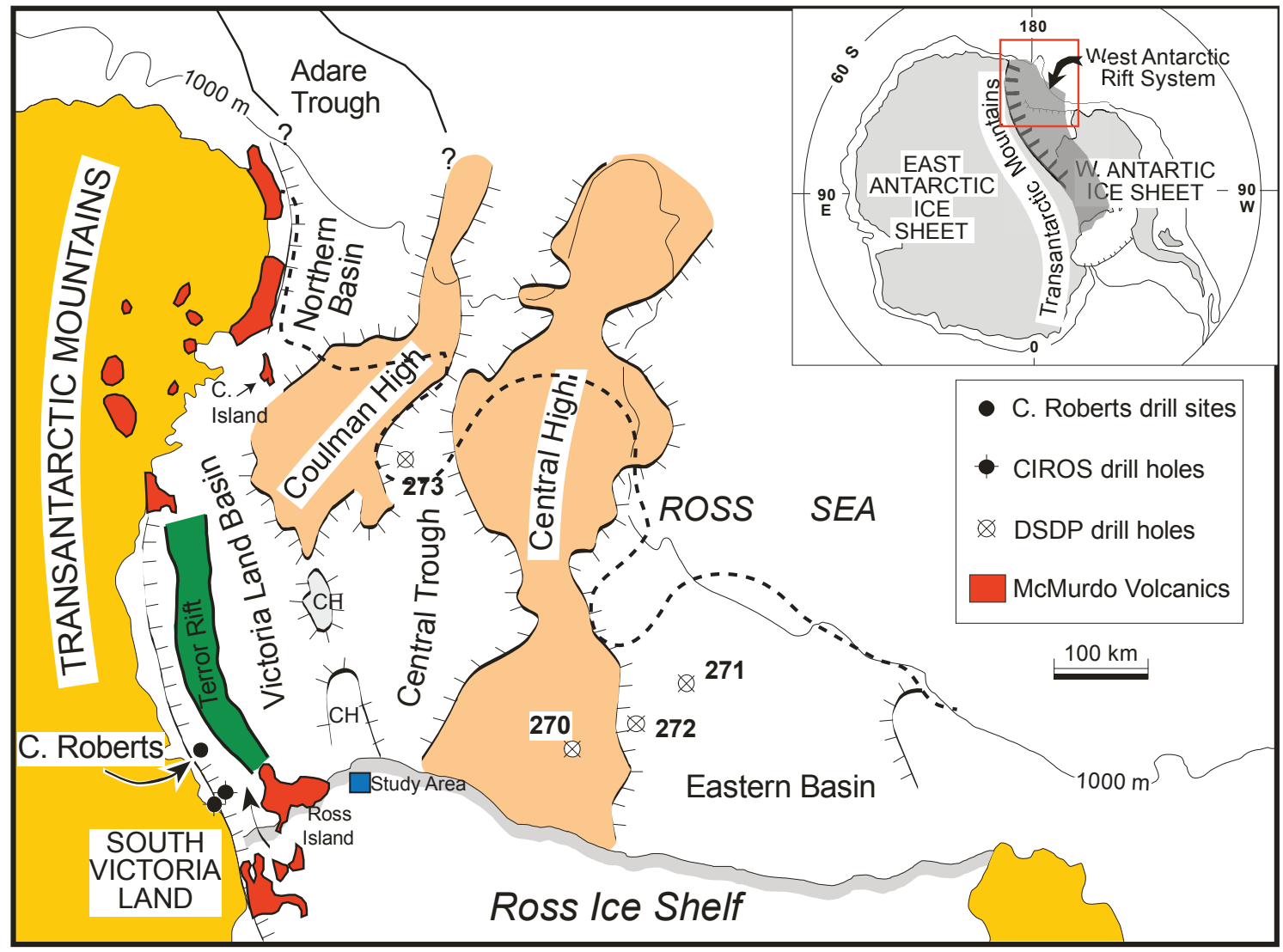

Figure 2.1: Map of the tectonic setting in the Ross Sea. Ross Sea rift basins and Transantarctic Mountains are components of the West Antarctic Rift System. CH $=$ Coulman High, C. Island = Coulman Island, Blue square = study area. Dashed line is the proposed extent of the grounding line during the LGM from Shipp et al. (1999). Map modified from Henrys et al. (2007).

the Coulman and Central Highs (Henrys et al., 2007; Figure 2.1). The latest extension in the WARS has occurred in the Terror Rift, which is located within the Victoria Land Basin, Western Ross Sea (Figure 2.1; Henrys et al., 2007). Ross Island is located at the southern extension of the Terror Rift (Hall et al., 2007), and the island is comprised of three volcanoes; Mount Bird, Mount Terror and Mount Erebus. Mt Bird and Mt Terror are older volcanic complexes, and evolved as basalt shield volcanoes between 4.6-3.8 and 1.7-1.3 Ma, respectively (Wright and Kyle, 1990a; Wright and Kyle, 1990b). Mt Erebus is the youngest volcano on Ross Island, and the highest volcano in the McMurdo Volcanic Group (Kyle and Cole, 1974). The Mt Erebus building phase started between 1.3-1.0 Ma, and reached its present day configuration only 0.25 Ma (Esser et al., 2004). The absence of Ross Island in the Pliocene could explain why an ice shelf was not sustained in the Ross Sea during this time (McKay et al., 2009). Alternatively, climate may have been too warm for ice shelf development (e.g. Naish et al., 2009; McKay et al., 2012a). 


\subsection{Geological setting}

The eastern part of the Ross Ice Shelf is bounded by the TAM which acts as a physical barrier between the EAIS and WAIS. South of Minna Bluff, the TAM are composed of seven major rock units, of which the oldest dates are Precambrian, and the youngest are Quaternary in age. Between Byrd Glacier and Minna Bluff, the TAM contain four major basement rock divisions, the Byrd Group, the Granite Harbour Intrusive Complex, the Beacon Group and the Ferrar Group, dating from Cambrian to Paleozoic and consisting of a range of metasedimentary, metamorphic and igneous rocks (Craddock, 1972). The Byrd Group are a series of shallow marine sediments, located on the southern margin of the Byrd Glacier, and are dominated by marbles and limestone, but also includes shales, sandstones and conglomerates. The folding and low grade metamorphism observed in the Byrd Group occurred during the Ross Orogeny (Late Cambrian to Early Ordovician; Craddock, 1972).

The Granite Harbour Intrusive Complex was formed during and after the Ross Orogeny, consequently both granites and mylonitic granites are observed. The Granite Harbour Intrusive Complex intrudes the Byrd Group and older rock units (Craddock, 1972). The Kukri Peneplain, an erosional surface, can be found throughout the TAM, and is unconformably overlain by the Beacon Group, a sequence of continental sedimentary rocks. The Beacon Group can be observed throughout the area between Minna Bluff and the Byrd Glacier and contains coal measures, sandstones, and conglomerates. The age of this succession ranges from Devonian to Triassic (Craddock, 1972). The Beacon Supergroup is intruded by doleritic sills, dykes and plugs, known as the Ferrar Group (Craddock, 1972). At the north eastern outlet part of the Byrd Glacier, Horney Bluff, is an outcrop of metamorphosed granites, namely the Horney Formation (Borg et al., 1989).

To the north, Ross Island (Mt Bird, Mt Terror and Mt Erebus), Mt Discovery and White and Black Island are part of the McMurdo Volcanic Group (MVG), which began evolving in the Pliocene (Wright and Kyle, 1990a). The rocks in the MVG contain alkali-basalt deposits of intraplate origin (Craddock, 1972), including small anorthoclase phonolite vents on Mt Erebus (Moore and Kyle, 1990), and pyroclastic breccias are found at Cape Crozier, Mt Terror (Wright and Kyle, 1990b). 


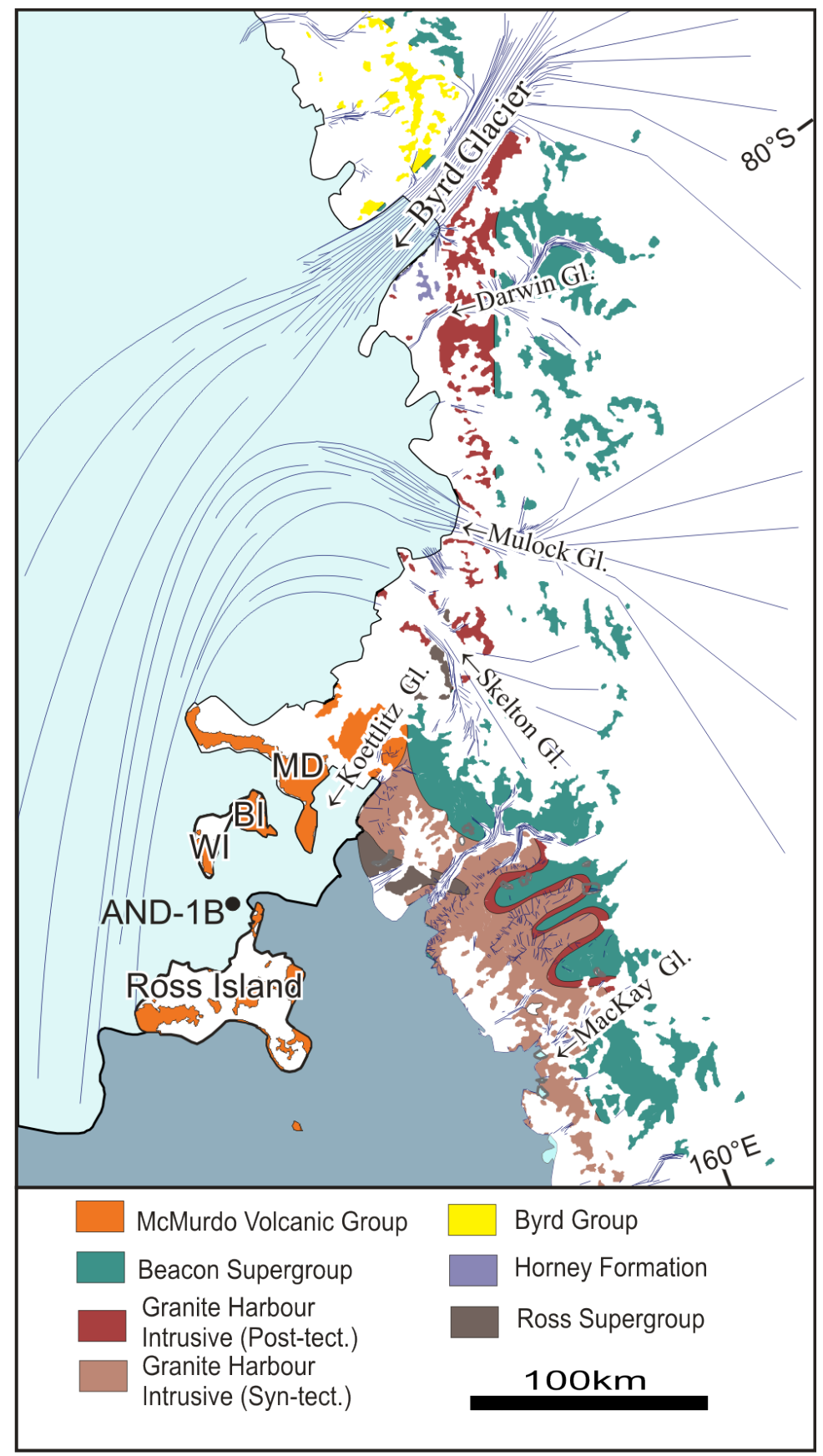

Figure 2.2: Geological map from the Transantarctic Mountains. Modern ice flow direction (blue lines) are also shown. Image from McKay (2008).

\subsection{Holocene climate}

From the 19th century, it was recognized that the configuration of the Earth's rotation around the sun was responsible for the long term glacial-interglacial cycles, known as Milankovitch cycles (Milankovitch, 1941). Superimposed on the Milankovitch-scale glacial-to-interglacial cycles, changes of shorter duration have been identified in ice and sediment cores. 


\section{Ice cores}

Ice cores drilled in Antarctica provide a continuous climatic history over the past 800 kyr, which in turn can be correlated with other paleoclimate records (Jouzel et al., 2007). These ice cores contain a number of useful proxies, including local surface temperature and direct measurements of atmospheric carbon dioxide. Some of the longest ice core records originate from the East Antarctic Plateau, but ice cores that are drilled closer to the coastal margins are believed to be influenced by regional signals controlled by the oceans and tropospheric circulations (Stenni et al., 2010). Steig et al. (2000) record that the Taylor Dome shows a rapid warming after the LGM, followed by a sudden cooling event before the onset of warmer temperatures in the Holocene. However, the chronology of the Taylor Dome core has been called into question due to the applied dating technique (e.g. Mulvaney et al., 2000). By comparing several ice core records from across Antarctica, Masson et al. (2000) document that the early Holocene optimum occurred between 11,500 and 9000 years ago. Ice cores near the Ross Sea show a secondary warm period between 7000 and 5000 years ago (Masson et al., 2000). The Talos Dome Ice CorE (TALDICE) from Northern Victoria Land near the Ross Sea, has provided a temperature record from the last $250 \mathrm{kyr}$ (Stenni et al., 2010). The $\delta^{18} \mathrm{O}$ data of TALDICE suggest the last glacial termination started at $18.2 \pm 0.7 \mathrm{ky} \mathrm{BP}$, triggered by orbital cycles and intensified by the feedback of $\mathrm{CO}_{2}$ (Shakun et al., 2012), with the Antarctic Isotope Maximum 1 at $14.7 \pm 0.3 \mathrm{ky}$ BP. This coincides with the onset of the Antarctic Cold Reversal (ACR) cooling, which reversed a period of late glacial warming (e.g. pre-Bolling warming) and lasted until $12.7 \pm 0.3 \mathrm{ky}$ BP (Figure 2.3; Stenni et al., 2010), after which warming recommenced. Ice cores in East Antarctica, both Dome $\mathrm{C}$ and Vostok ice cores, recorded a relatively warm period during the Holocene, and this has been correlated with the Holocene climatic optimum, between 10 and 6 ka (Ciais et al., 1992).

\section{Sediment core from the Antarctic Peninsula}

Sediment cores can be used as a proxy to obtain temperature data. Sea surface temperature (SST) can be derived by using the paleothermometer TEX $_{86}$ (tetraether index consisting of 86 carbon atoms) analysis on the contents of the sediment cores (Wuchter et al., 2004). A sediment core drilled on the western side of the Antarctic Peninsula, has been analysed to produce a SST record from TEX $_{86}$ going back to 12 ky BP (Shevenell et al., 2011). They interpret SST in terms of an overall cooling trend during the Holocene, with fluctuation between $2-4^{\circ} \mathrm{C}$. Warm periods occurred 


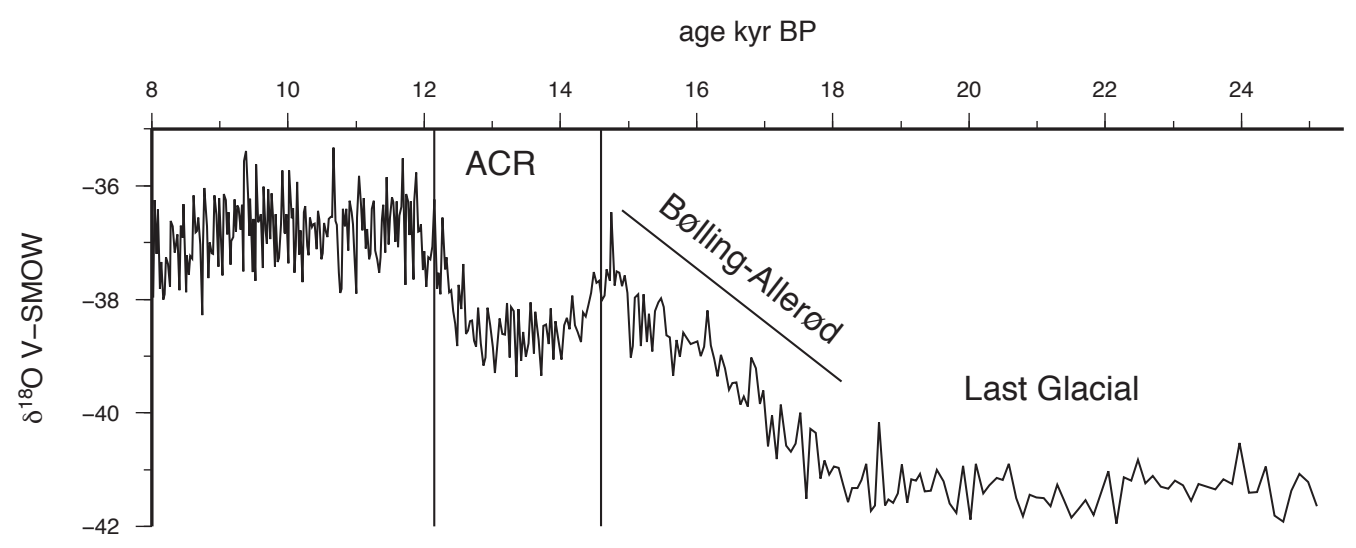

Figure 2.3: $\delta^{18} \mathrm{O}$ V-SMOW versus kyr BP from TALDICE record. The ACR-cooling occurs between 14.7 and 12.7 kyr BP. Data from Stenni et al. (2010).

at $11,9,6.5,5.5,3.5$ and 1 kyr BP, and cold intervals occurred centred on $\sim 7.5,6$, 4.5, 2.3 and 0.2 kyr BP (Shevenell et al., 2011).

\subsection{Ross Ice Shelf}

\subsubsection{Ross Sea during the last glacial advance}

Along the Siple Coast, at the present day grounding line of the Ross Ice Shelf, five ice streams drain the WAIS. Ice streams have relatively high velocities, of a few hundreds of metres per year, compared to the rest of the ice sheet that flows at a rate of tens of metres per year (Shabtaie and Bentley, 1987). The sediment moved by these fast flowing ice streams is deposited in wedges, known as grounding-line wedges (Alley et al., 2007), and these features have been imaged using radar at the present day grounding line along the Siple Coast (Anandakrishnan et al., 2007). The presence of megascale glacial lineations (MSGL), grounding zone wedges and other subglacial geomorphic features detected by swath bathymetry and shallow seismological data on the continental shelf of the Ross Sea have been used to constrain the extent of the ice sheet at the last glacial maxima and the retreat of the grounded ice (Shipp et al., 1999). During the LGM, both the EAIS and WAIS expanded, and Shipp et al. (1999) identified grounding zone wedges at $\sim 74^{\circ} \mathrm{S}$, suggesting that the LGM ice sheet extended north of Coulman Island in the western Ross Embayment (Figure 2.1).

In addition to swath bathymetry, shallow seismological data and sediment cores collected in the Ross Sea help constrain the timing and extent of the grounded ice sheet and there is also terrestrial evidence for the presence of an ice advance during 
the LGM. The advance of a grounded ice sheet in the Ross Embayment deposited the Ross Sea drift in the mouth of the Taylor Valley. Radiocarbon dates on algae found in the Ross Sea drift showed the Taylor Valley was blocked off by grounded ice and had glacial lakes at 23,800 ${ }^{14} \mathrm{C}$ yr BP (Hall and Denton, 2000). The youngest ice-dammed lake in the Taylor Valley has been dated at 8,340 ${ }^{14} \mathrm{C}$ yr BP, implying that a grounded ice sheet was present at the mouth of Taylor Valley between 23,800 and 8,340 ${ }^{14}$ yr BP (Hall and Denton, 2000).

Geological data and models are used to estimate the contribution from East and West Antarctic ice to the grounded ice and the Ross Ice Shelf during the LGM. The reconstruction the marine ice sheet in the Ross Embayment by Stuiver et al. (1981) suggests that the WAIS ice streams that flow into the Ross Ice Shelf at the Siple Coast extended during the LGM to the edge of the continental shelf, and that the grounded ice/Ross Ice Shelf was almost exclusively sourced from West Antarctica. Subsequent models constrained by terrestrial (e.g. fresh gravel drift along the TAM outlet glaciers and raised profiles related to thickened glaciers during the LGM) and marine data (e.g. sea floor features including northeast-southwest trending ridges and troughs, and provenance studies of glacimarine tills), suggest that the ice in the western Ross Sea was derived from East Antarctica and that the ice in the eastern Ross Sea was derived from West Antarctica (Figure 2.4; Licht and Fastook, 1998; Shipp et al., 1999; Denton and Hughes, 2000).

To better constrain where the ice was derived from in different parts of the Ross Sea, Licht et al. (2005) analysed clasts in LGM till from the Ross Embayment and compared it to rocks from the continental source areas in both East and West Antarctica. The sediments deposited in the Eastern and Central Ross Sea during the LGM indicate a West Antarctic provenance, whereas the glaciers from the TAM in East Antarctica (like the Nimrod and Byrd Glacier), extended south and deposited the sediments in the Western Ross Sea (Licht et al., 2005). At the Coulman High site, the paleo-ice flow is likely to be derived from the Byrd Glacier region (Licht et al., 2005).

\subsubsection{Holocene retreat history of the Ross Ice Shelf}

Using short sediment cores collected in the embayment in conjunction with seismic profiles, the retreat of the grounded ice and the Ross Ice Shelf has previously been reconstructed (e.g. Licht et al., 1996; Domack et al., 1999; Shipp et al., 1999; Licht et al., 2005; McKay et al., 2008). Domack et al. (1999) analysed short sediment 
WAIS-dominated

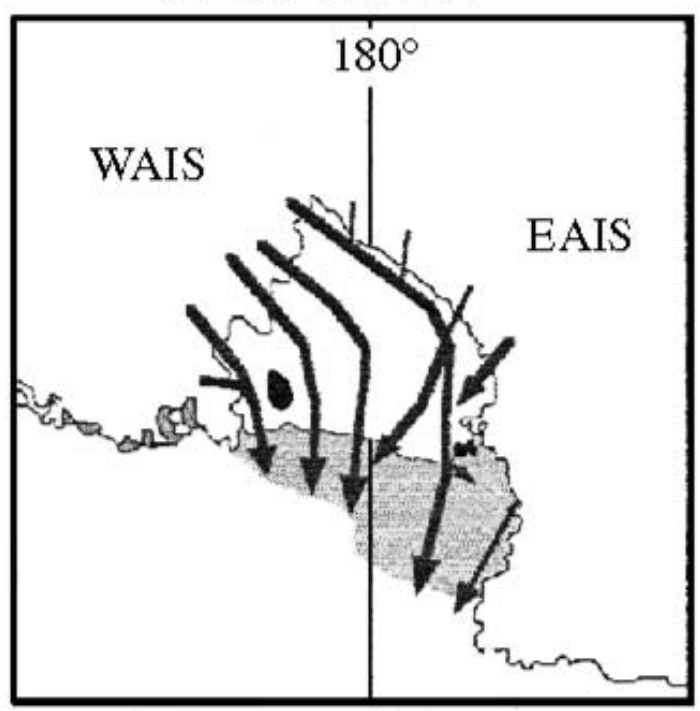

Stuiver et al., 1981
WAIS-EAIS balanced

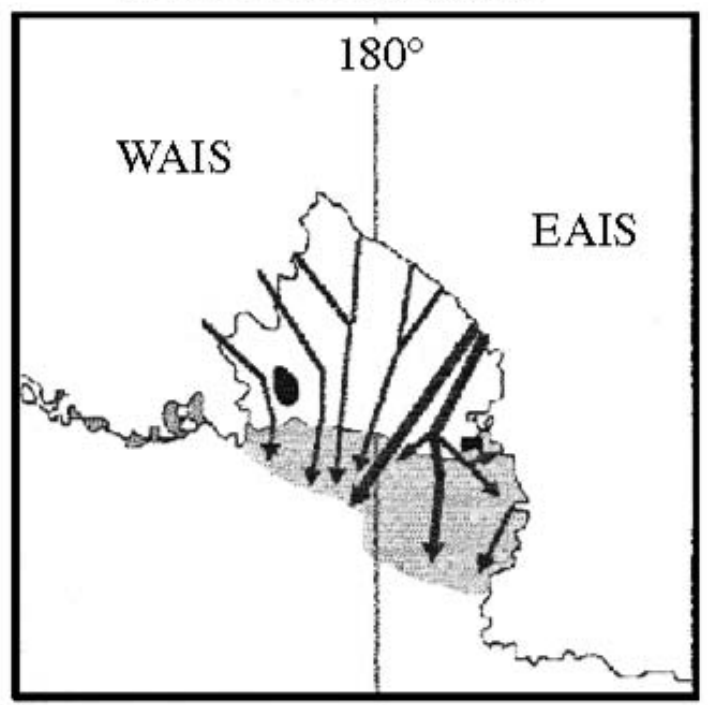

Licht and Fastook, 1998

Denton and Hughes, 2000

Figure 2.4: Schematic reconstructions of the potential paleoice-flow models of the WAIS and EAIS into the Ross Ice Shelf at the LGM. Left flow model is from Stuiver et al. (1981). Right flow model from Licht and Fastook (1998) and Denton and Hughes (2000). Wider lines indicate higher velocity ice flow. The shaded area shows the Ross Sea continental shelf. WAIS = West Antarctic ice sheet, EAIS = East Antarctic ice sheet. Image from Licht et al. (2005).

cores collected in the Western Ross Sea, using them to identify a retreat succession of four different facies that were related to the retreat of the ice in the Western Ross Sea.

In ascending order, this succession consists of:

1. Massive, mud-rich diamicton, representing subglacial deposition.

2. Stratified granulated facies consisting of pelletized, sandy, muddy gravel, representing a "lift-off" facies; deposited sea-ward of the grounding line in a sub-ice shelf environment via melt out of the basal debris layer at the base of a floating ice shelf.

3. Silt and clays with a well-sorted, very fine grained sand component, representing a sub-ice shelf deposition beneath an ice shelf that is free of basal debris and characterised by very low sedimentation rates. This is known as the "null zone".

4. Siliceous mud and ooze, representing deposition in an open-marine setting. 


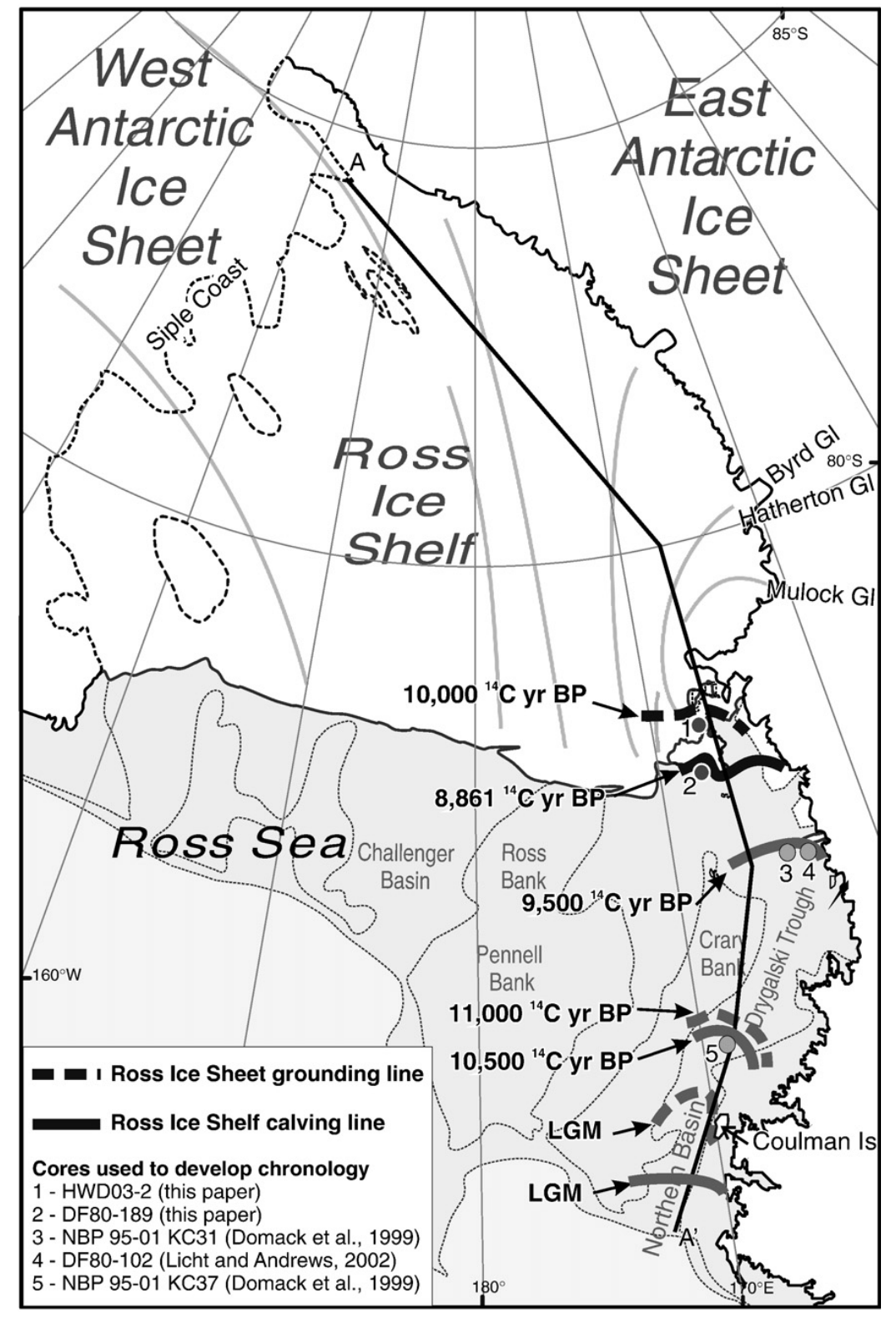

Figure 2.5: Map of Ross Embayment with the retreat of the grounded ice sheet and Ross Ice Shelf since the LGM. Chronology is shown with black lines and circles from McKay et al. (2008), and grey lines and circles based on previous work. Solid lines indicate maximum position of the calving line for the Ross Ice Shelf, and dashed lines indicate maximum position of the grounding line. Image from McKay et al. (2008).

This facies are discussed in more detail in Chapter 5. The radiocarbon chronology of these sediment cores suggest that the grounding line had retreated south of the Drygalski Trough $\left(75.5^{\circ}\right.$ south) by $11{ }^{14} \mathrm{C}$ ka and that open-marine conditions were established around $9.5^{14} \mathrm{C}$ ka (Figure 2.5; Domack et al., 1999). Three gravity cores collected from underneath the McMurdo Ice Shelf (north west corner of the RIS) during 2003 and 2006, and six piston cores from the Erebus Basin and Lewis Basin 

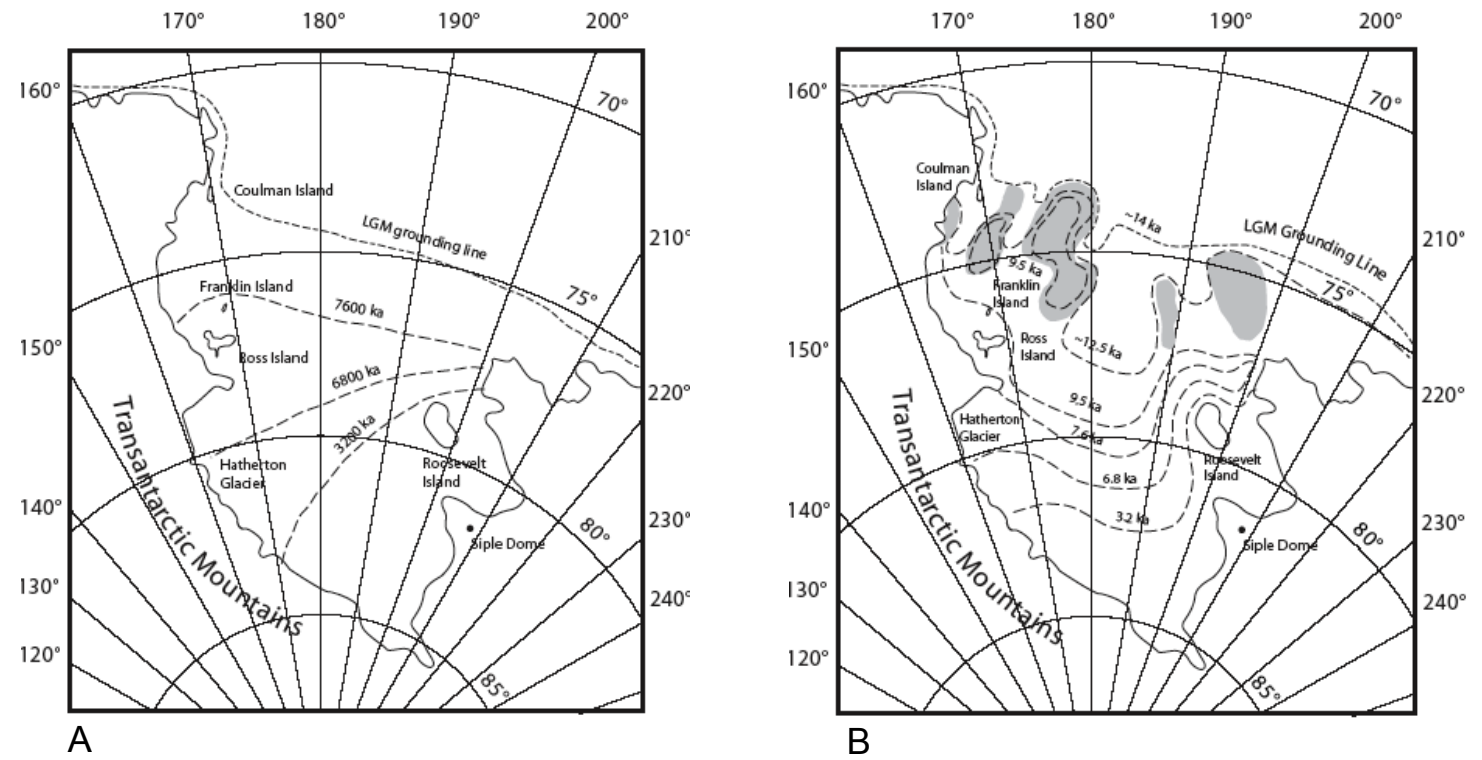

Figure 2.6: Two scenarios for the deglaciation of the Ross Sea, dashed lines represent the location of the grounding line. A) Cartoon depicting the swinging gate model from Conway et al. (1999). The grounding line retreats faster along the TAM. B) Cartoon depicting the saloon door model from Ackert Jr. (2008). The grounding line positions are based on the mapping in the Ross Sea by Shipp et al. (1999). Image from Ackert Jr. (2008).

collected by the USCGC Glacier as part of Operation Deep Freeze (DF) in 1979-80 were investigated by McKay et al. (2008) to provide the southern most constraint on the retreat history of the ice sheet in the Ross Embayment (Figure 2.5). They concluded that the lift-off of the ice sheet in McMurdo Sound occurred $\sim 10,100{ }^{14} \mathrm{C}$ years BP, while the calving line of the ice shelf retreated to the northern region of Ross Island prior to $\sim 8,900{ }^{14} \mathrm{C}$ years BP but had not retreated further south than Ross Island at any time in the Holocene (McKay et al., 2008). The youngest delta to remain from proglacial lakes in the Taylor Valley has been dated to be $8,340{ }^{14} \mathrm{C}$ yr BP, and therefore Hall and Denton (2000) suggests that the ice sheet was still grounded at that time in McMurdo Sound. Samples of shells and seal skins from raised beaches along the Scott Coast were used to produce a radiocarbon chronology to date the deglaciation. They imply that the deglaciation of an ice shelf within McMurdo Sound took place between 8,340 and 5,730 ${ }^{14} \mathrm{C}$ yr BP (Hall and Denton, 1999). Conway et al. (1999) proposed a deglaciation model for a grounded ice sheet in the Ross Sea based on chronology along the Scott Coast, Hatherton Glacier (TAM) and Roosevelt Island (Figure 2.6). They suggest a 'swinging gate' model for the retreat of the grounding line; as the grounded ice retreated along the Scott and Shackleton Coast, and reached Hatherton Glacier around 6,800 yr B.P., the ice stayed pinned to Roosevelt Island until 3,200 yr B.P. (Conway et al., 1999). 
The extent of the grounding line during the LGM as mapped out by Shipp et al. (1999), suggests that the position of the grounding line at various stages in the retreat of the grounded ice was governed by the bathymetry of the Ross Sea. Ackert Jr. (2008) uses this data to advocate for a 'saloon door' retreat of the ice sheet, where the retreat of the ice sheet was governed by a calving embayment over the Eastern Basin (Figure 2.6).

The timing of the retreat of the ice shelf is still contentious due to the issues arising from the use of ${ }^{14} \mathrm{C}$ from acid insoluble organic (AIO) component of bulk sediment to produce a chronology. There are problems associated with using radiocarbon dating on the Antarctic continental shelf, due to the recycling of old carbon in the environment, as well as the variations in the reservoir age of marine ${ }^{14} \mathrm{C}$ carbonate material. For more information on the issues surrounding ${ }^{14} \mathrm{C}$ dates in the Antarctic, see Chapter 3, and the topic has been discussed extensively in previously published work (e.g. Gordon and Harkness, 1992; Andrews et al., 1999; Domack et al., 1999; McKay et al., 2008). Due to the inability to obtain a well constrained chronology, the timing and potential drivers of the retreat are still debated.

During the last deglaciation, there were two occasions when sea level rose substantially in a relative short time frame, named meltwater pulse (mwp) 1A and 1B. Fairbanks (1989) dated the first rise in sea level of $20 \mathrm{~m}$ between 17,100 and 12,500 yr BP, mwp-1A. The second substantial increase in sea level, was $28 \mathrm{~m}$ and took place around 9,500 yr BP, mwp-1B (Fairbanks, 1989).

McKay et al. (2008) suggest that it is possible that the accelerated retreat between the outer Drygalski Trough to Ross Island, within 1,000 years, preceded meltwater pulse 1B or maybe even contributed to mwp-1B. Mackintosh et al. (2011) support this finding and suggest that the retreat of the EAIS since the LGM was caused by both the warming of the ocean and rapid sea level rise and imply mwp-1A was from the Northern Hemisphere, initiating lift off of the grounding line. At 14 kyr the ice sheet began to retreat, even though this was during the Antarctic Cold Reversal and the temperatures were cooling as recorded in Antarctic ice core temperature records (e.g. Blunier et al., 1998). A new chronology derived for mwp-1A derived from drill cores in Tahiti, suggest the event happened between 14.65 and $14.31 \mathrm{ky}$ BP (Deschamps et al., 2012), and this date pre-dates the initial retreat of the Ross Ice Shelf, hence the retreat could not have contributed to mwp-1A. Subsequent southern ocean warming from $\sim 13$ ky led to the accelerated rate of the Antarctic 
ice margin retreat at this time (Barrows et al., 2007). However, Deschamps et al. (2012) suggest that up to $50 \%$ of the increase in sea level from mwp-1A could have been sourced from the Antarctic continent.

\subsection{Antarctic studies on Holocene sediment cores in different regions}

Other areas along the Antarctic continent have been studied using short sediment cores to obtain the climate and ice shelf history since the LGM.

\section{Prydz Bay}

The Lambert Glacier/Amery Ice Shelf system in East Antarctica, located in the Indian Ocean sector, drains about a fifth of the ice from East Antarctica into Prydz Bay (Hambrey et al., 1991). Analyses on sediment cores collected from underneath the Amery Ice Shelf were done to determine the retreat of the ice shelf (Hemer and Harris, 2003). There are six units recognized in the sediment core, and these are comparable with the facies succession of Domack et al. (1999). In ascending order, unit 6 represents a subglacial environment, unit 5 and 4 were deposited close to the grounding zone, unit 3 and 2 represent a sub-ice shelf environment, and unit 1 is a siliceous mud and diatom ooze, indicative of open or near open marine conditions (Hemer and Harris, 2003). An increase of a sea ice diatom Fragilariopsis curta at ca. $5700{ }^{14} \mathrm{C}$ yr BP is interpreted to be a retreat of the ice shelf (Hemer and Harris, 2003).

\section{Antarctic Peninsula}

Like all parts of Antarctica, the ice sheets and ice shelves encompassing the Antarctic Peninsula advanced during the LGM. One such region was in Marguerite Bay, west of the Antarctic Peninsula, where a paleo-ice stream extended to the edge of the continental shelf (Ó Cofaigh et al., 2005). There are two distinctive tills deposited in the Marguerite Bay; the lower till is a massive diamict with increased shear strength, and decreased porosity. The upper till is soft, has a lower shear strength and increased porosity. Ó Cofaigh et al. (2005) interpret that this facies is deposited underneath the paleo-ice stream when the ice had advanced, as it was cored beneath a MSGL. Bulk sediment dates from the diatom ooze suggest that glacimarine environment was established $12,610 \pm 110{ }^{14} \mathrm{C}$ yr BP. During open marine conditions, icebergs inhabit locations which were previously occupied by ice 
shelves. Icebergs can carry coarse sediment and as the icebergs melt, the sediments rain out as ice rafted debris (IRD). The IRD from icebergs is often differentiated from sediments carried by ice shelves and grounded ice, as it will have a different provenance (Pudsey and Evans, 2001). Consequently, the presence of IRD in sediment cores is interpreted that open water conditions were seen at that time.

Sediment cores collected near ice shelves located in the most northern part of the Antarctic Peninsula were analysed to determine their retreat history (eg. Pudsey and Evans, 2001; Bentley et al., 2005). The presence of IRD suggest that the ice shelves retreated in the early-mid Holocene (e.g. Pudsey and Evans, 2001; Bentley et al., 2005). 


\section{Chapter 3}

\section{Methodology}

\subsection{Field work}

The Antarctic Geological Drilling (ANDRILL) program conducted a site survey on the Ross Ice Shelf, at Coulman High to the east of Ross Island (Figure 3.1), between November 2010 and January 2011 as part of preparations for a planned drilling project targeting an Early Cenozoic sequence (see Appendix A for details on studies conducted). This thesis investigates the collection of sediment cores recovered during the field campaign.

Table 3.1: The four sites at Coulman High used for the sedimentological data recovery.

\begin{tabular}{|c|c|c|c|}
\hline Site & Location & Total Cores & Longest Core $(\mathrm{mm})$ \\
\hline Site 1 & "S $77^{\circ} 29.3^{\prime}$ E $171^{\circ} 34.2^{\prime}$ & 8 & 520 \\
\hline Site 2 & 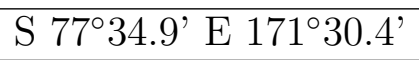 & 6 & 1095 \\
\hline Site 3 & 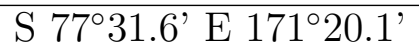 & 10 & 1290 \\
\hline Site 4 & S $77^{\circ} 28.1^{\prime}$ E $171^{\circ} 36.2^{\prime}$ & 4 & 850 \\
\hline
\end{tabular}

\subsubsection{Core collection}

Similar to the ANDRILL McMurdo Ice Shelf project, a hot water drill was used to melt a hole with a diameter greater than $40 \mathrm{~cm}$ through the ice shelf (e.g. Naish et al., 2007). A gravity corer designed by the Alfred Wegener Institute (AWI) was then lowered down the hole using a winch (e.g. Barrett et al., 2005). A plastic core barrel of ranging length from $0.5 \mathrm{~m}$ to $2 \mathrm{~m}$, was fitted into the base of the gravity corer. The corer was allowed to free fall between 5 to 20 metres above the sea floor, with the height being determined by an encoder and tape applied on the rope of the winch. Once the core was recovered, the liner was cut to length and sealed. 


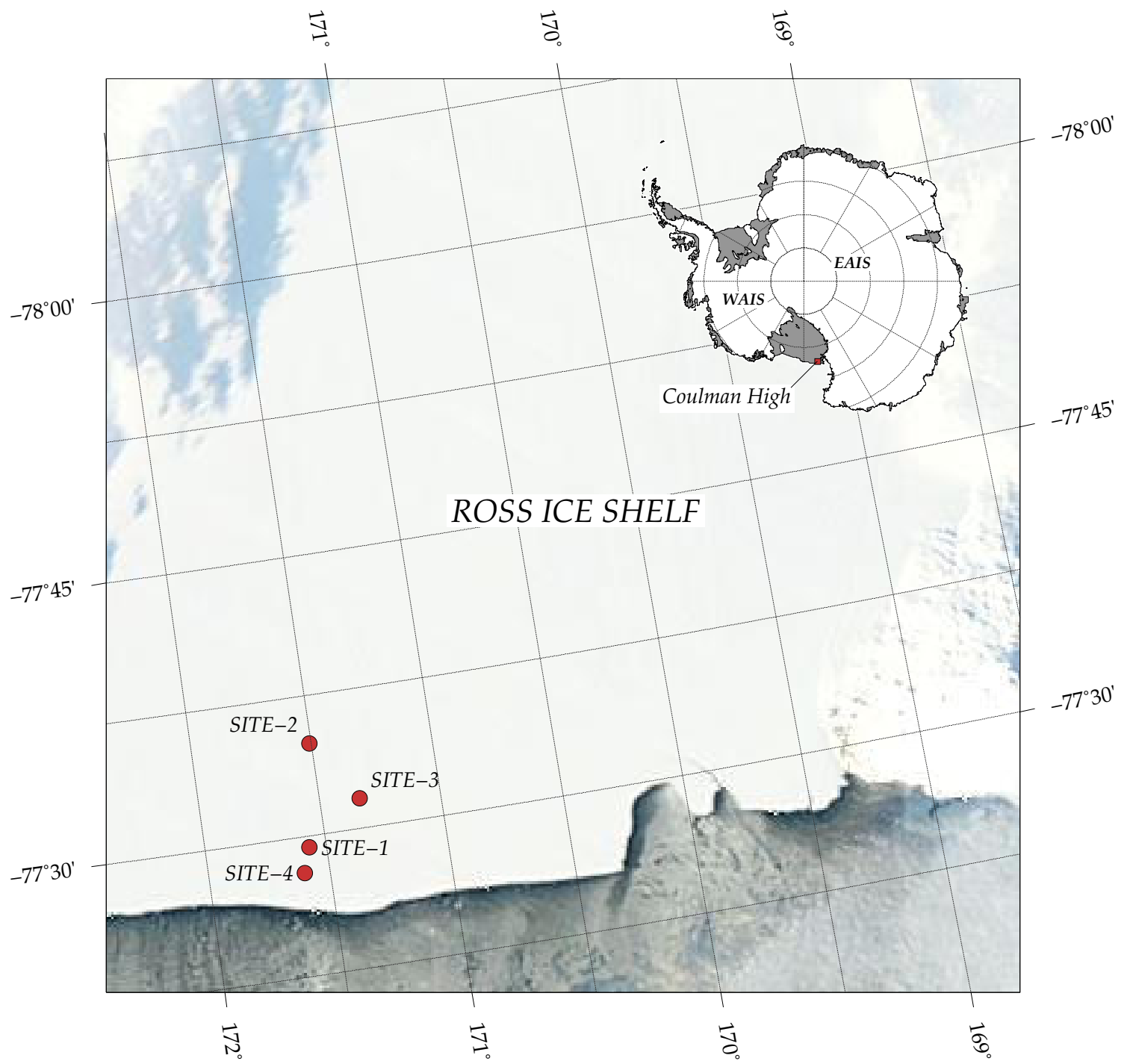

Figure 3.1: The four site locations relative to the calving line position in early 2011, occupied during the ANDRILL site survey.

In total 28 cores were collected, and these were stored horizontally at a temperature of $4^{\circ} \mathrm{C}$ and transported back to New Zealand for analysis (Table 3.1).

\subsubsection{Video imagery underneath the ice shelf}

A digital camera was placed in a reinforced submersible housing, attached to a frame with an additional reinforced vessel to provide lighting. This device was made to record the changes in the ice hole, i.e. how many days it would take for the ice hole to close, and to observe the presence or absence of englacial debris within the ice, and it was then lowered to image the sea floor. 


\subsection{Laboratory work}

\subsubsection{Core X-ray images}

All sediment cores were X-rayed at NIWA, Wellington. The X-rays were examined to determine bioturbation, macroscopic sedimentary structures, observed IRD and changes that occurred down core. This was used to decide which cores were to be split and sampled. These images helped with the description of the sediment, e.g. to identify subtle laminae or gravel clasts, and assisted in the correlation between cores from each locality.

\subsubsection{Physical properties}

A multi-sensor core logging (MSCL) tool at Otago University was used to scan the cores for physical properties. The whole core scan measured magnetic susceptibility (loop), gamma ray attenuation, electrical resistivity and P-wave velocity. Seven cores were split open and described, sampled for smear slides and additional scanning was conducted on the half round for magnetic susceptibility (point) and colour reflectance (RGB and spectral). Sediment samples from three cores were sent to AWI in Bremerhaven, Germany, for additional analysis. These included: water content\%, wet bulk density, porosity, grain density, dry bulk density, total organic carbon, total inorganic carbon, total nitrogen and biogenic opal.

\subsubsection{Core description/lithostratigraphy}

The lithological description scheme applied to describe the facies follows that of the ANDRILL McMurdo Ice Shelf Project (Naish et al., 2006). If the sediment contains no gravel, the principal name is determined by the relative abundance of sand, silt and clay (after Mazullo et al., 1988). For example, if the sediment contains between 75 and $100 \%$ sand and between 25 and $50 \%$, it is a silty sand (Figure 3.3).

If the sediment has more than $50 \%$ pelagic biogenic material, it is classified as an ooze, moderated by the most specific biogenic grain type. For example, if the diatoms exceed $50 \%$, then the sediment is categorized as a diatom ooze (Naish et al., 2006). Sediments that comprise out of both biogenic and terrigenous components, are classified according to the percentage present in the sample, where 10-25\% is biogenic is called bearing, $25-50 \%$ is rich, and more than $75 \%$ is classified as an ooze. For example, if the sample contains more than $75 \%$ diatoms, and the remainder is silt, the name of the sediment is a silt-bearing diatom ooze (Figure 3.2; Naish et al., 2006). 
For terrigenous sediments containing gravel, with less than $50 \%$ biogenics, the Moncrieff classification was used. If the sediment contains any terrigenous clastic gravel, then the principal name is determined by the abundance of gravel and the sand to mud ratio of the terrigenous clastic matrix (after Moncrieff, 1989). The percentage of sand in conjunction with the percentage of gravel determines whether the sediment is a clast-rich muddy diamict, or a clast-rich sandy diamict (Table 3.2).

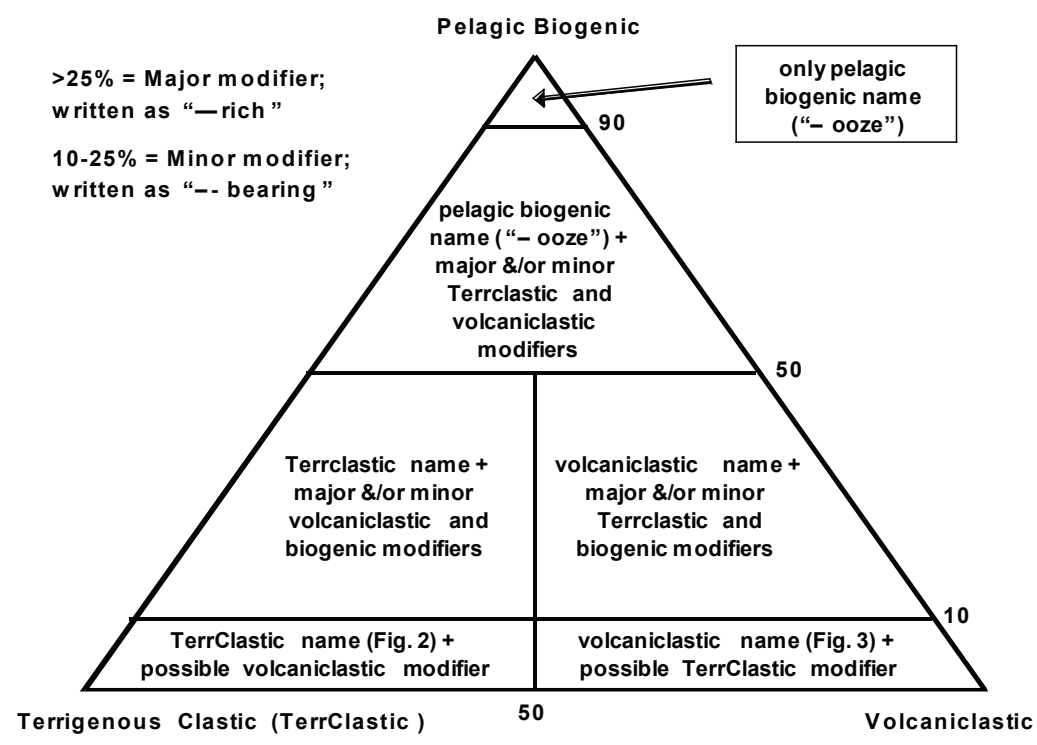

Figure 3.2: Classification scheme for granular sediments that are mixtures of pelagic biogenic, volcaniclastic, and terrigenous clastic particles (after Naish et al., 2006).

Table 3.2: Classification scheme for terrigenous clastic sediments containing a gravel component (after Moncrieff, 1989).

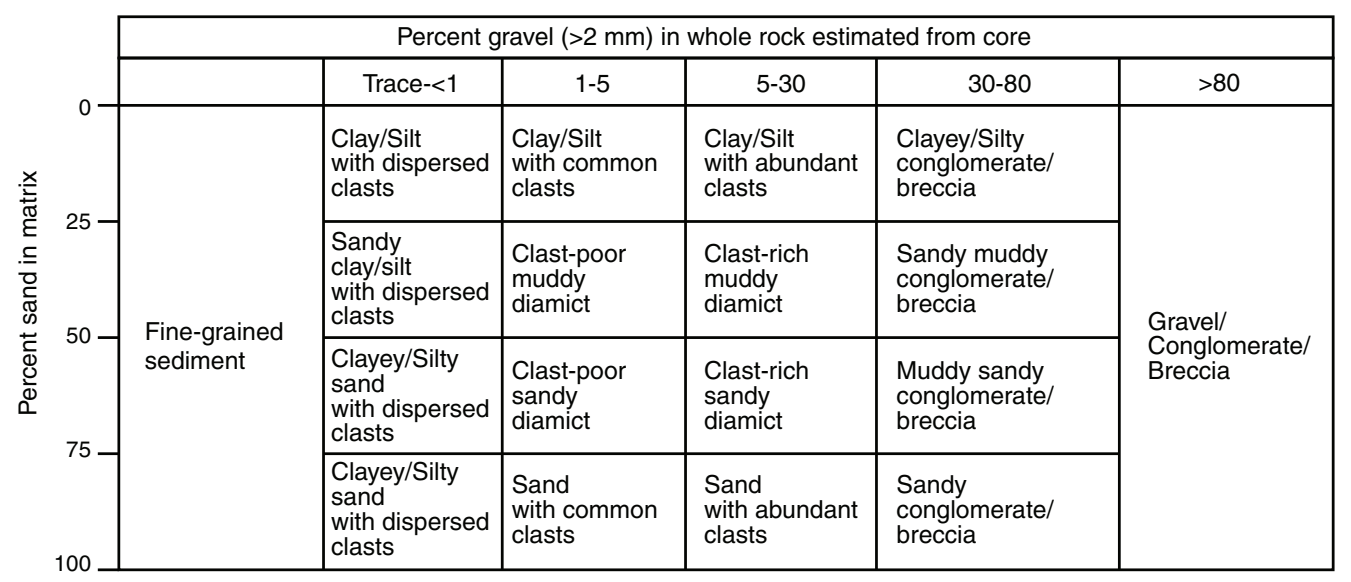




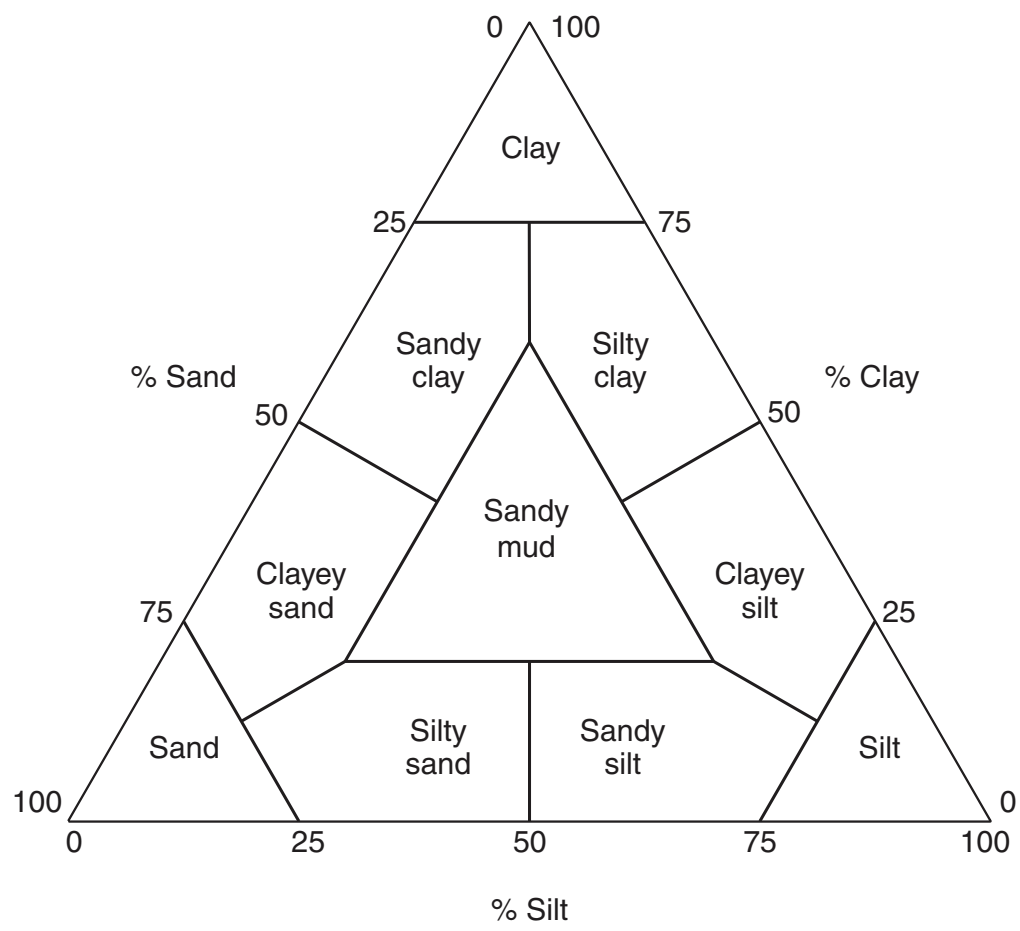

Figure 3.3: Classification scheme for terrigenous clastic sediments lacking a gravel component (after Mazullo et al., 1988).

\subsubsection{Grain size analysis}

The samples were dried in a $50^{\circ} \mathrm{C}$ oven and both the wet and dry weights were recorded to determine the water content in addition to the water content values measured by AWI, and the values were comparable. The dried samples were then soaked in buffered water $\left(1 \mathrm{~g} \mathrm{NaHCO} 3\right.$ and $0.1 \mathrm{~g} \mathrm{Na}_{2} \mathrm{CO}_{3}$ with $5 \mathrm{l}$ of distilled $\left.\mathrm{H}_{2} \mathrm{O}\right)$ to disaggregate the sample. Once the sample was disaggregated, it was wet sieved at $150 \mu \mathrm{m}$. The sample fraction greater than $150 \mu \mathrm{m}$ was weighed and sieved at 500 $\mu \mathrm{m}$ and $2000 \mu \mathrm{m}$. The sample fraction finer than $150 \mu \mathrm{m}$ was treated with hydrogen peroxide and sodium hydroxide to remove the organic and silica component of the sediment (Lewis and McConchie, 1994). The samples were then analysed by the Beckman Coulter LS13320 to obtain a grainsize distribution of the $<150 \mu$ m fraction. Due to errors associated with the laser particle analyzer, the upper boundary for the clay particle size has been adjusted to $8 \mu \mathrm{m}$ for certain calculations (e.g. sortable silt).

\subsubsection{Petrology}

After the samples were wet sieved at $150 \mu \mathrm{m}$, the coarse fraction of the sediment was weighed and dry sieved again at 2000 and $500 \mu \mathrm{m}$. Sand grains in the $2000-500 \mu \mathrm{m}$ 
fraction were made into thin-sections for petrographic analysis. To characterise the minerals and rock fragments, the Indiana point counting method was used where the thin section was systematically moved across the field of view, and every grain was counted. This method accounts for both rock fragments and individual minerals (Suttner, 1974; Suttner et al., 1981). For each facies of the core, the aim was to obtain a total of 300 counts of the different rock fragments and minerals. For some samples this was not possible due to a lack of sufficient grains $>500 \mu \mathrm{m}$. All samples were counted multiple times to check reproducibility.

\subsubsection{Diatom abundance}

To analyse the core for diatom abundance, 23 samples with an average weight of $0.652 \mathrm{~g}$ were taken from core CHGC 08. The sediment was air dried before being treated with $5 \mathrm{ml}$ hydrogen peroxide, and subsequently diluted in $95 \mathrm{ml}$ of distilled water, followed by stirring of the sample to get an uniform distribution. A micro pipette was then used to place $80 \mu \mathrm{l}$ onto a slide coverslip and then mounted to a slide using Norland Optical Adhesive.

The absolute abundance of diatom frustules per gram sediment was determined using equation 3.1. following the methodology of Konfirst et al. (2012).

$$
\text { Abundance }=\frac{F}{\left(C_{\text {sample }} * V_{\text {sample }}\right) *\left[\left(f / v * A_{(f / v)}\right) / A_{C S}\right]}
$$

$\mathrm{F}$ is the number of frustules counted in a sample, $\mathrm{C}_{\text {sample }}$ is the concentration of sediment in suspension, $\mathrm{V}_{\text {sample }}$ is the volume of sample used, $\mathrm{f} / \mathrm{v}$ is the number of fields of view observed in a sample, $\mathrm{A}_{f / v}$ is the area of a field of a view, and $\mathrm{A}_{C S}$ is the area of the cover slip. Samples were examined under an optical reflected light microscope at either 400x or 1000x magnification, with a minimum of 300 diatom specimens (both whole and fragments) counted per sample. Multiple samples were counted twice to check for reproducibility.

\subsection{7 $\quad{ }^{14} \mathrm{C}$ Chronology}

\section{Bulk sediment samples}

A total of twenty samples were taken from cores CHGC-08 and CHGC-14 for radiocarbon analysis. The bulk sediment samples were analysed at the Rafter Radiocarbon Laboratory, where ${ }^{14} \mathrm{C}$ ages were acquired from bulk organic carbon in acid insoluble organic (AIO) remnants. 
Several studies have addressed issues associated with applying radiocarbon dating to Antarctic marine sediments (e.g. Gordon and Harkness, 1992; Andrews et al., 1999; Domack et al., 1999; McKay et al., 2008). The Antarctic marine sediments contain a low proportion of datable organic material and by using the accelerator mass spectrometry (AMS) method, small amounts of organic carbon can be analysed for ${ }^{14} \mathrm{C}$ (Domack et al., 1989). Despite the ability to analyse small amounts of organic carbon, problems still prevail in establishing a reliable ${ }^{14} \mathrm{C}$ chronology. Firstly, there is a reservoir age problem; living marine organisms in Antarctic waters contain low ${ }^{14} \mathrm{C}$ concentrations in comparison with marine organisms living elsewhere (Andrews et al., 1999; Domack et al., 1999). This results in modern material giving apparent radiocarbon ages up to several thousand of years old. Secondly, the reworking of older sediment containing organic material is frequent in the Ross Sea (Domack et al., 1999). The reworking of the 'dead' carbon (older than $50 \mathrm{ky}$ ) in sediment produces an older ${ }^{14} \mathrm{C}$ age (Andrews et al., 1999).

One solution to this is using a correction factor calculated by subtracting the core top ages from down core ages. This is only applicable if there is no change of facies, as a constant supply of dead carbon is assumed. However, this is clearly a compromise since core top sediment ages range from 2000 to $21,000{ }^{14} \mathrm{C}$ yr BP (Andrews et al., 1999). Despite the problems associated with ${ }^{14} \mathrm{C}$ chronology due to the general lack of carbonate material in the Ross Sea, it is the most common method of dating short sediment cores that span the last 18 ka due to the paucity of other datable material.

\section{Foraminifera samples}

Due to the lack of calcareous material, a dedicated core was sampled exclusively for foraminifera. X-ray imagery suggests that there is a coherent stratigraphy between cores from each site. Core CHGC-07 from Site 2 was chosen as the dedicated core for whole round sampling to extract foraminifera from the sediment. The stratigraphy of core CHGC-07 was readily tied to core CHGC-08 using X-ray imagery. Based on the location of key facies in the interpretation (Chapter 4), the core was sampled at two intervals. The top of the core (four samples between 3 and $30 \mathrm{~cm}$ ), and between 50 and $70 \mathrm{~cm}$, every two centimetres on both halves of the core, i.e. 20 samples (Figure 3.4). All samples were soaked in buffered water $\left(1 \mathrm{~g} \mathrm{NaHCO}_{3}\right.$ and $0.25 \mathrm{~g} \mathrm{Na}_{2} \mathrm{CO}_{3}$ in $5 \mathrm{l}$ of distilled $\mathrm{H}_{2} \mathrm{O}$ ) and once disaggregated, sieved at 63 $\mu \mathrm{m}$. The $>63 \mu \mathrm{m}$ fraction was collected in a filter and placed under a heat lamp until the sample was dry. The dried samples were examined under a microscope and 


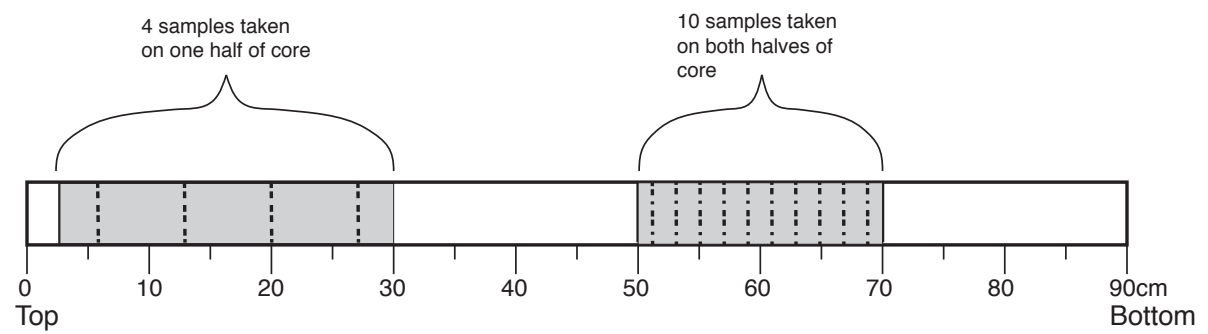

Figure 3.4: Schemactic diagram of CHGC-07 to illustrate where the samples were taken from.

calcareous foraminifera were picked.

Two samples from 50 and $52 \mathrm{~cm}$ were sent to the Rafter Radiocarbon Laboratory for analysis. The first sample contained a total of one hundred planktic Neogloboquadrina pachyderma, whereas the second sample contained 340 different benthic foraminifera. As a reservoir age, 1200 years was chosen to correct the radiocarbon years. This date has been used in previous studies done in the Ross Sea (e.g. Domack et al., 1999; Licht and Andrews, 2002). To correct and calibrate the ages, IntCal09 was used, with a reservoir age of 1200 years (Reimer et al., 2009). 


\section{Chapter 4}

\section{Results}

\subsection{Sea floor and ice shelf imagery}

Video images of the sea floor showed it was covered by boulders up to $1.5 \mathrm{~m}$ in diameter, with a pelagic drape, and a wide variety of flora and fauna, including brittle stars, sponges and anemones, was present (Figure 4.1). This indicates that bioturbation beneath this calving line proximal location beneath the Ross Ice Shelf is pervasive. The footage of the ice hole revealed that there is no glacial debris present within the ice shelf at Coulman High.

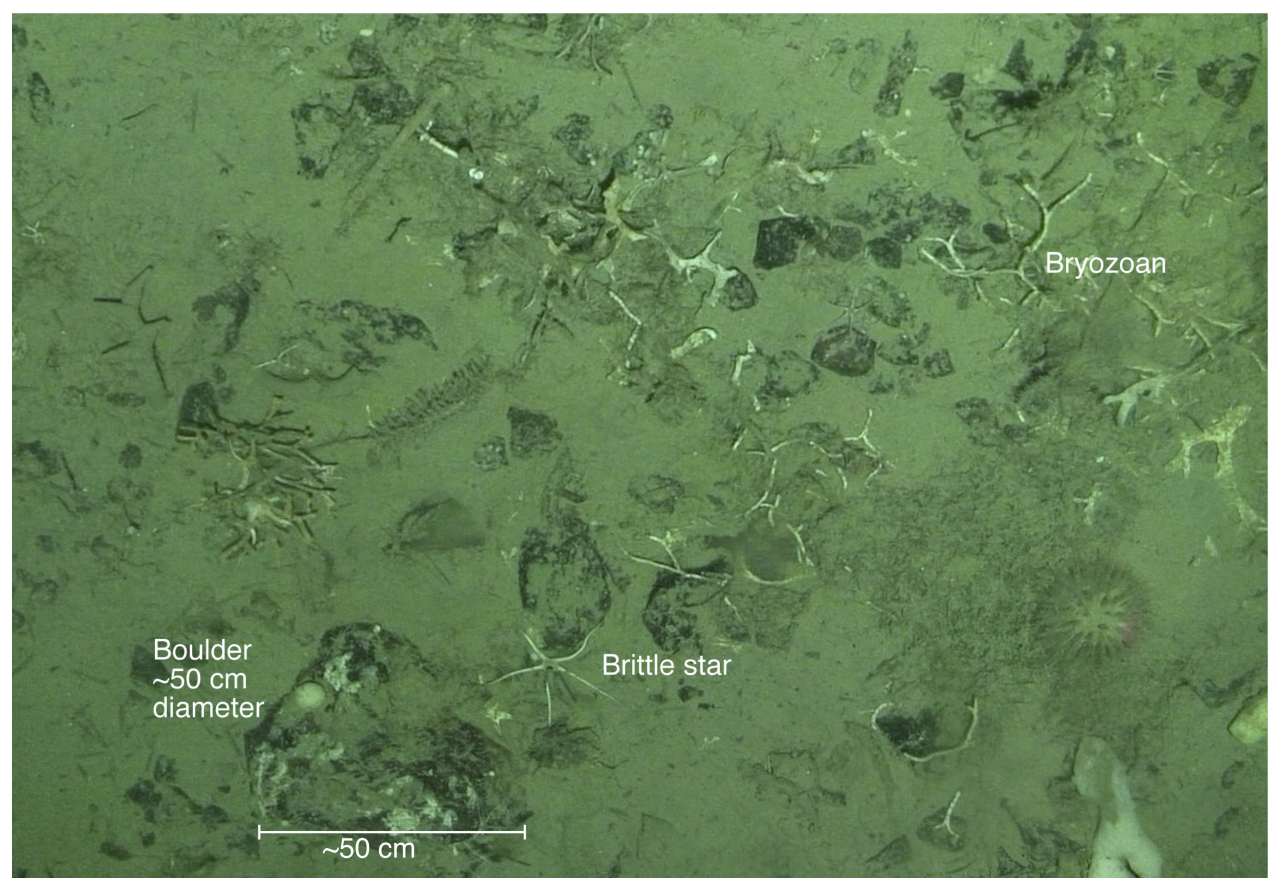

Figure 4.1: Image from the sea floor. Species present in the figure are Brittle stars and Bryozoans. Numerous boulders and cobbles occur on the sea floor, e.g. the boulder in the bottom left corner. 


\subsection{Core lithostratigraphy}

Eight cores were split and described with lithological units assigned on the basis of colour, sedimentary structures and texture. Smear slides were taken at different horizons in the cores to determine diatom content. Summarised descriptions from all split cores follows. Figure 4.2 shows the comparison of the cores from the four different sites. Detailed core logs are provided in Appendix B.

\subsubsection{Site 1 cores}

The site is $5 \mathrm{~km}$ south of the present day calving line, and was open water after C-19 calved off in 2002. The ice shelf at this location was $261 \mathrm{~m}$ thick, with a water depth of $798 \mathrm{~m}$.

Core CHGC-05, Site 1, $38 \mathrm{~cm}$ long (Figure 4.2):

- Unit $1(0-14 \mathrm{~cm})$ is a yellow-green, sandy-mud rich diatom ooze with common to abundant clasts, ranging from granules to pebbles. The unit has a mottled texture with cm-scale oval burrows. The lower contact is bioturbated over 4 $\mathrm{cm}$.

- Unit 2 (14-38 cm) is a medium-dark grey, clayey silt with abundant clasts. Clasts range from granule to pebble size and clast lithology is highly variable. The clasts include lithified diamict, mafic volcanics, and granites, and large mineral grains including feldspars and quartz. 


\subsubsection{Site 2 cores}

The site is currently $15 \mathrm{~km}$ south of the calving line, and the ice shelf remained in

place over the site after C-19 calved off in 2002. The ice shelf at this location was $273 \mathrm{~m}$ thick, with a water depth of $862 \mathrm{~m}$.

Core CHGC-0\%; Core CHGC-08; Core CHGC-11

- Unit 1 (CHGC-07, 0-20 cm; CHGC-08, 0-19 cm; CHGC-11, 0-22 cm) is a yellow-green sandy mud-bearing, diatom ooze with dispersed black granular clasts. Bioturbation is pervasive throughout the unit, with well preserved diatoms, sponge spicules and radiolarians. Lower contact is bioturbated over $5 \mathrm{~cm}$.

- Unit 2 (CHGC-07, 20-50 cm; CHGC-08, 19-46 cm, CHGC-11, 22-50 cm) is a light-grey silty-clay with a slightly mottled appearance. Uncommon to common bioturbation occurs throughout. In CHGC-07, a single green laminae of $5 \mathrm{~mm}$ thickness occurs at $48 \mathrm{~cm}$. The unit has a sharp lower contact.

- Unit 3 (CHGC-07, 50-74 cm; CHGC-08, 46-64 cm; CHGC-11, 50-82 cm) is a greenish-grey silty clay with laminae. The laminae are characterised by couplets of mm-scale silty clay and sub-mm-scale clayey silt. Dispersed to common clasts occur throughout the unit. In CHGC-07, a gravel/sand-rich bed occurs between 56-61 cm, while in CHGC-11 a distinct gravel/sand-rich bed occurs at $57-58 \mathrm{~cm}$, and a $\mathrm{cm}$ thick sandy-mud laminae occurs at $76 \mathrm{~cm}$. The lower contact of the unit is sharp.

- Unit 4 (CHGC-07, 74-80 cm; CHGC-08, 64-78 cm) is a light grey silty clay with mm-scale laminae that increases in thickness towards the bottom of the unit. Laminae are defined by colour alternations between dark and light grey. Fragmented diatoms are present but rare (1-2\% in smear slide estimates). The lower contact is sharp.

- Unit 5 (CHGC-07, 74-80 cm; CHGC-08, 78-87 cm) is a medium-dark grey clayey-silt with abundant clasts. The clasts range from granule to pebble size. The lower contact is sharp.

- Unit 6 (CHGC-07, 80-89.5 cm; CHGC-08, 87-107 cm; CHGC-11, 82-97 cm) is a dark grey massive, clast-rich muddy diamict. It is poorly sorted with clasts ranging from granular to pebble size and lithologies of clasts is highly variable and include lithified diamict, mafic volcanics, feldspars, quartz and granites. The clasts are angular in shape and some display striae and facets. 


\subsubsection{Site 3 cores}

The site is $10 \mathrm{~km}$ south of the calving line, and was immediately adjacent to the calving line when C-19 calved off in 2002. The ice shelf at this location was $253 \mathrm{~m}$ thick, with a water depth of $860 \mathrm{~m}$.

Core $C H G C-14$, Site 3, $127 \mathrm{~cm}$ :

- Unit $1(0-30 \mathrm{~cm})$ is yellow-green clayey silt-rich diatom ooze with dispersed clasts ranging from granule to pebble size. The unit grades down into a grey colour. The lower contact is bioturbated over $4 \mathrm{~cm}$.

- Unit $2(30-80 \mathrm{~cm})$ is a medium-dark grey clayey silt to silty clay. Fine and coarse silt are intermixed at mm-scale to $\mathrm{cm}$-scale. Several bands of gravel and sand occur at 37-38 $\mathrm{cm}$ and $75-77 \mathrm{~cm}$. Well-defined mm-scale parallel laminae occur between $35-42 \mathrm{~cm}$. The unit fines down core. Dispersed clasts are present throughout, ranging from granule to pebble size. The lower contact is intercalated with the underlying unit over an interval of $3 \mathrm{~cm}$.

- Unit $3(80-127 \mathrm{~cm})$ is a dark grey clast-rich muddy diamict, with pervasive contorted bedding. The unit is stratified at cm-scale, as defined by grain size variations. The clasts present range from granule to pebble size.

Core $C H G C-17$, Site 3, $106 \mathrm{~cm}$ :

- Unit $1(0-8 \mathrm{~cm})$ is a yellow-green clayey-silt bearing diatom ooze with abundant clasts. Clasts range from granule to pebble in size. Concentration of granules and coarse sand occurs at 5-7 cm, with a wide range of clasts lithologies, including quartz, feldspar and volcanics. The lower contact of the unit is sharp.

- Unit $2(8-106 \mathrm{~cm})$ is a medium-dark grey massive clayey-silt with abundant clasts with the exception of two brown coloured beds occurring at 11.5-13.5 $\mathrm{cm}$ and at $15-17 \mathrm{~cm}$. The beds within this unit vary from silty clay and clayey silt with a gradational upper and lower contact. 


\subsubsection{Site 4 cores}

The site is $3 \mathrm{~km}$ south of the calving line, and was open water when C-19 calved off in 2002. The ice shelf at this location was $269 \mathrm{~m}$ thick, with a water depth of 864 m.

Core CHGC-22, Site 4, $75 \mathrm{~cm}$ (Nb after being cored with an aluminium barrel, core was transferred into plastic casing, resulting in post-coring disturbance):

- Unit $1(0-12 \mathrm{~cm})$ is a diatom ooze intermixed with light-medium grey clayey silt. There are common clasts throughout the unit ranging from granule to pebble size. The lower contact of the unit is sharp.

- Unit $2(12-75 \mathrm{~cm})$ is a medium grey fine sandy mud with abundant clasts. Bioturbation is present at $15.5 \mathrm{~cm}$. Contorted bedding is present towards bottom of the unit. Clasts are present throughout and range from granule to pebble size.

Core CHGC-23, Site 4, $50 \mathrm{~cm}$ (Nb after being cored with an aluminium barrel, core was transferred into plastic casing, resulting in post-coring disturbance):

- Unit $1(0-11 \mathrm{~cm})$ is a yellow green clayey-silt rich diatom ooze. There are common granule sized clasts throughout. The lower contact of the unit is sharp.

- Unit $2(11-18 \mathrm{~cm})$ is light to medium grey clayey silt intermixed with yellow green diatom ooze beds occurring at $16-17 \mathrm{~cm}$. The stratification is defined by colour. Bioturbation is present, with common clasts, granule size. The lower contact is sharp.

- Unit $3(18-50 \mathrm{~cm})$ is a medium-dark grey clast-rich muddy diamict. Clasts range from granule to pebble size. 


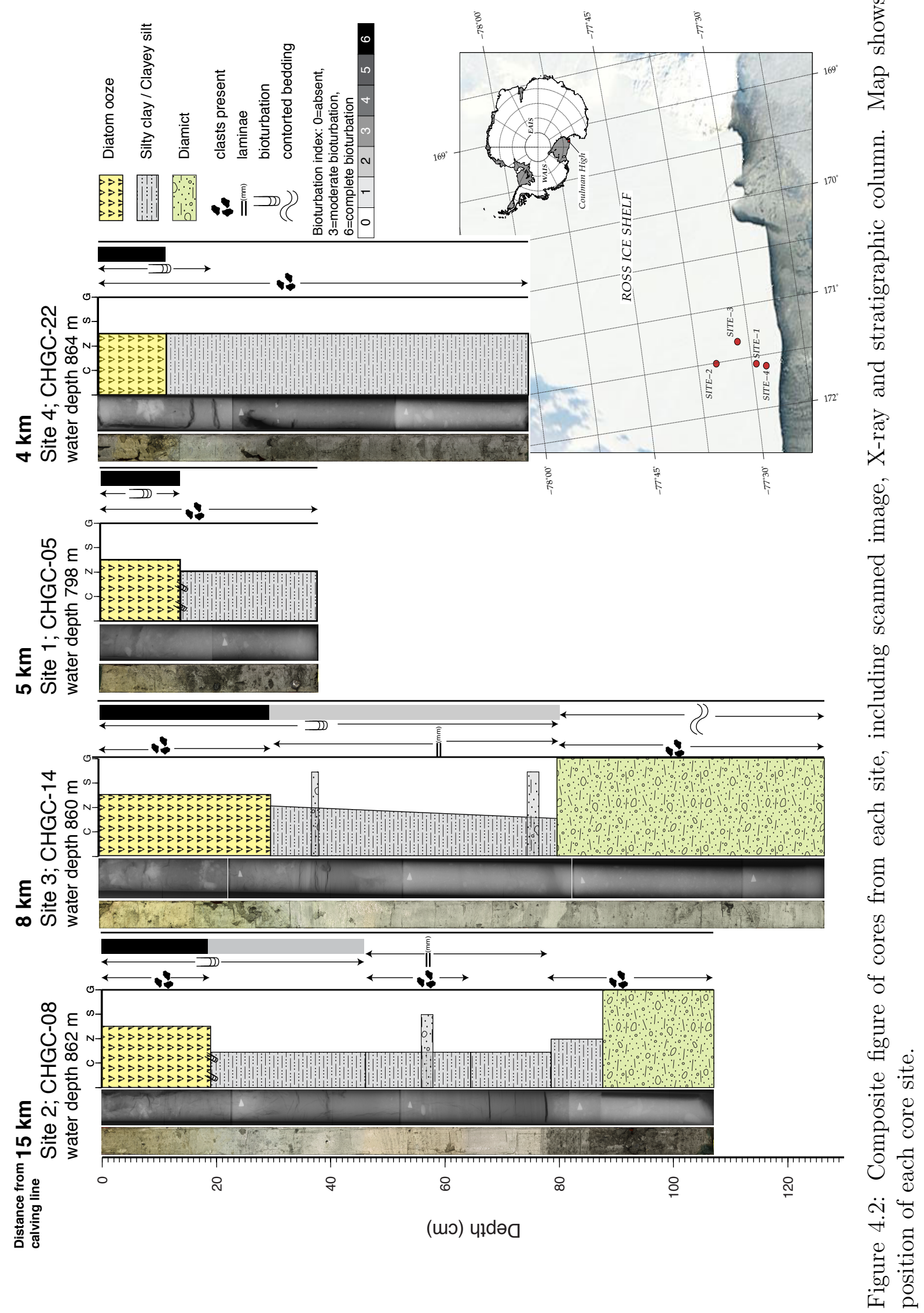




\subsection{Facies description}

The lithostratigraphic descriptions in the previous section were used alongside sedimentological parameters and physical properties to develop the following lithofacies scheme. The facies descriptions are based on common lithologic, biogenic and physical property attributes across all core sites, although most analyses (grain size, diatom content; Figure 4.7, and petrography) were conducted on CHGC-08 (Figure 4.3). This core was chosen as all three cores at Site 2 had a coherent and consistent stratigraphy. Cores at Site 1 were all $<40 \mathrm{~cm}$ in length, while at Sites 3 and 4 the stratigraphies were variable between cores and may represent mass flow deposits (see Chapter 5 for criteria to distinguish subglacial transport and deposition by mass flow processes), and are therefore unlikely to provide a coherent retreat history of the LGM ice sheet.

\subsubsection{Massive diamict. Facies Dm.}

At the base of CHGC-07 (Site 2; 80-89.5 cm), 08 (Site 2; 87-107 cm), 11 (Site 2; $82-97 \mathrm{~cm}$ ), 14 (Site 3; 80-127 cm), 22 (Site 4; 12-75 cm) and 23 (Site 4; 18-50 cm) is a clast-rich muddy diamict. The diamicts are massive, and the clasts are randomly orientated. The clasts range from granule to pebble size, where the largest pebbles are restricted to $<50 \mathrm{~mm}$ in length, due to the diameter of the plastic core barrels. The clasts consist of a wide range of lithologies, including lithified diamict, dolerite, granite, carbonates, quartz and feldspar grains, biotite schist and metamorphosed rock fragments (Figure 4.5). The provenance of the sand fraction shows a distinct Transantarctic Mountain signature with abundant biotite schist, quartz, lithified diamict and heavy minerals. The heavy minerals are likely to be derived from the Ferrar Dolerite, whereas the quartz grains could be derived from the Byrd Group, the Beacon Group or the Granite Harbour Intrusives, all located near the Byrd Glacier (Craddock, 1972). The grain size is dominated by sand and gravel, and there is a multi-modal distribution for the fine sediment fraction (i.e. fine sand, silt and clay) (Figure 4.7; B.13). The diatom content in the unit is low $\left(0.27 \times 10^{9} \mathrm{v} / \mathrm{g}\right)$, with only small fragments preserved (Figure 4.4). The water content percentage ranges between 10 and 30 percent in this unit, and inversely correlates well with the density (Figure 4.7). Furthermore, magnetic susceptibility is higher in this unit, with a peak at 105 (x $10^{-5}$ SI units; Figure 4.7). The wet bulk density (WBD) is slightly increased in the diamict $\left(1.9 \mathrm{gcm}^{-1}\right)$, and the biogenic opal content is low (5\%) compared with the overlying sediment. 


\subsubsection{Mud with abundant clasts. Facies Mc.}

Mud with abundant clasts directly overlies the diamict in CHGC-07 and 08 (74-80 $\mathrm{cm} ; 75-87 \mathrm{~cm})$. The same lithology is found at the base of CHGC-05 (14-38 cm) and CHGC-17 $(8-106 \mathrm{~cm})$. The mud is medium to dark grey, and the clasts present are granule to pebble-sized. The weight percentage of grains $>150 \mu \mathrm{m}$ increases from $0 \%$ to $15 \%$ compared to the overlying mud unit (Figure 4.7; B.13). The $<150$ $\mu \mathrm{m}$ sediment fraction has a multi-modal distribution of fine sand, silt and clay (Figure B.14). The diatom concentration is $0.39 \times 10^{9} \mathrm{v} / \mathrm{g}$. The physical properties of this unit show an increase in magnetic susceptibility from 34 to 77 (SI units), and density from 1.5 to $1.8 \mathrm{gm} / \mathrm{cc}$. The water content shows the same inverse trend, dropping in this unit from $50 \%$ to $25 \%$ (Figure 4.7 ). The WBD $\left(1.746 \mathrm{~g} \mathrm{~cm}^{-1}\right.$ ) is slightly lower than in the underlying diamict, while the biogenic opal percentage $(5.8 \%$ ) slightly elevated (Figure 4.7$)$.

\subsubsection{Mud}

\section{Laminated mud. Facies Ml}

Mud in CHGC-07 (50-74 cm) and CHGC-08 (64-78 cm) are predominately silty clays (Figure 4.7). The silty clay is light to dark grey, with mm-scale laminations defined by colour alternations, light to dark grey, with the thickness increasing down core. In this unit, the sediment is well sorted with a uni-modal clay distribution (Figure 4.7). Diatom concentration is slightly elevated compared to the underlying units, $0.46 \mathrm{x}$ $10^{9} \mathrm{v} / \mathrm{g}$. Magnetic susceptibility and density are relatively low throughout the unit, and range between 29-38 SI and 1.44-1.53 gm/cc respectively (Figure 4.7).

\section{Laminated mud with clasts and diatoms. Facies Mc,l (DO)}

Sandy mud with common clasts and diatoms are present in CHGC-07 $(50-74 \mathrm{~cm}), 8$ (46-64 cm), $11(50-82 \mathrm{~cm})$ and $14(30-80 \mathrm{~cm})$. The unit contains mm-scale laminae distinguished by both colour and grain size (Figure 4.3; B.13). Granule-size clasts in this facies are common, and are striated with faceted surfaces. In CHGC-11 and $14,1-2 \mathrm{~cm}$ thick beds of sand are present. The petrology data show that there is a mix of source material, dominated by quartz and granite (both mylonitic and post tectonic granite; Figure 4.5). The diamict grains are distinctively different than the diamict grains in the massive diamict facies as they have an irregular shape and the matrix has a lower birefringence (Figure 4.6). At $53 \mathrm{~cm}$, calcite is common. Together with up to $15 \%$ in the $>150 \mu \mathrm{m}$ size fraction, the fine sediment fraction displays a poorly sorted multi-modal distribution. Diatom abundances are elevated relative 
to Facies $\mathrm{Mb}$ (above) and $\mathrm{Ml}$ (below), and reach a maximum of $0.74 \times 10^{9} \mathrm{v} / \mathrm{g}$ at $57 \mathrm{~cm}$. The diatoms are mainly fragmented, although the fragments are larger than in Facies $\mathrm{Mb}$ and $\mathrm{Ml}$ (Figure 4.4). In CHGC-07, foraminifera are present at 50 and $52 \mathrm{~cm}$. In a half round sample, $\sim 200$ foraminifera shells were present. The planktic species are dominated by Neogloboquadrina pachyderma, where there is a more diverse assemblage of benthic species, including: Lagena substratiata elegantula, Astrononion antarctica, Cibicides lobatulus, Rosalina globularis and Lagena distoma. The density slightly increases relative to Facies Mb and Ml (maximum value of 1.63 gm/cc) (Figure 4.7).

\section{Bioturbated mud. Facies Mb}

Bioturbated mud overlies the laminated muds in CHGC-07, CHGC-08, CHGC-11 and in CHGC-23, and is classified mostly as silty clays (Figure 4.7). The sediment is light to dark grey, with rare to common bioturbation. The bottom of the unit has a low diatom content $\left(0.37 \times 10^{9} \mathrm{v} / \mathrm{g}\right)$, which increases to the top of the unit (1.06 $\mathrm{x} 10^{9} \mathrm{v} / \mathrm{g}$ ). The fine sediment is dominated by clay (Figure 4.7). The biogenic opal content is between 8 and $24 \%$.

\subsubsection{Diatom ooze. Facies DO.}

Diatom ooze is present at the top of all cores examined. It has a mottled texture, indicative of persuasive bioturbation, with well preserved diatoms, sponge spicules and radiolarians observed in smear slides. The diatom concentration is $>1.9 \times 10^{9}$ $\mathrm{v} / \mathrm{g}$. The thickness of the unit varies only slightly between the sites, with the maximum thickness of $50 \mathrm{~cm}$ observed in CHGC-14. The lower contact of this facies is usually intensively bioturbated over $2-5 \mathrm{~cm}$. The terrigenous matrix component is a clayey-silt, with dispersed to common clasts, which vary in size from granules to pebbles. The lithology of the clasts are dominated by feldspar, quartz, granites and a minor basalt and carbonate component (Figure 4.5). A quarter of the counted feldspar grains are microcline. 


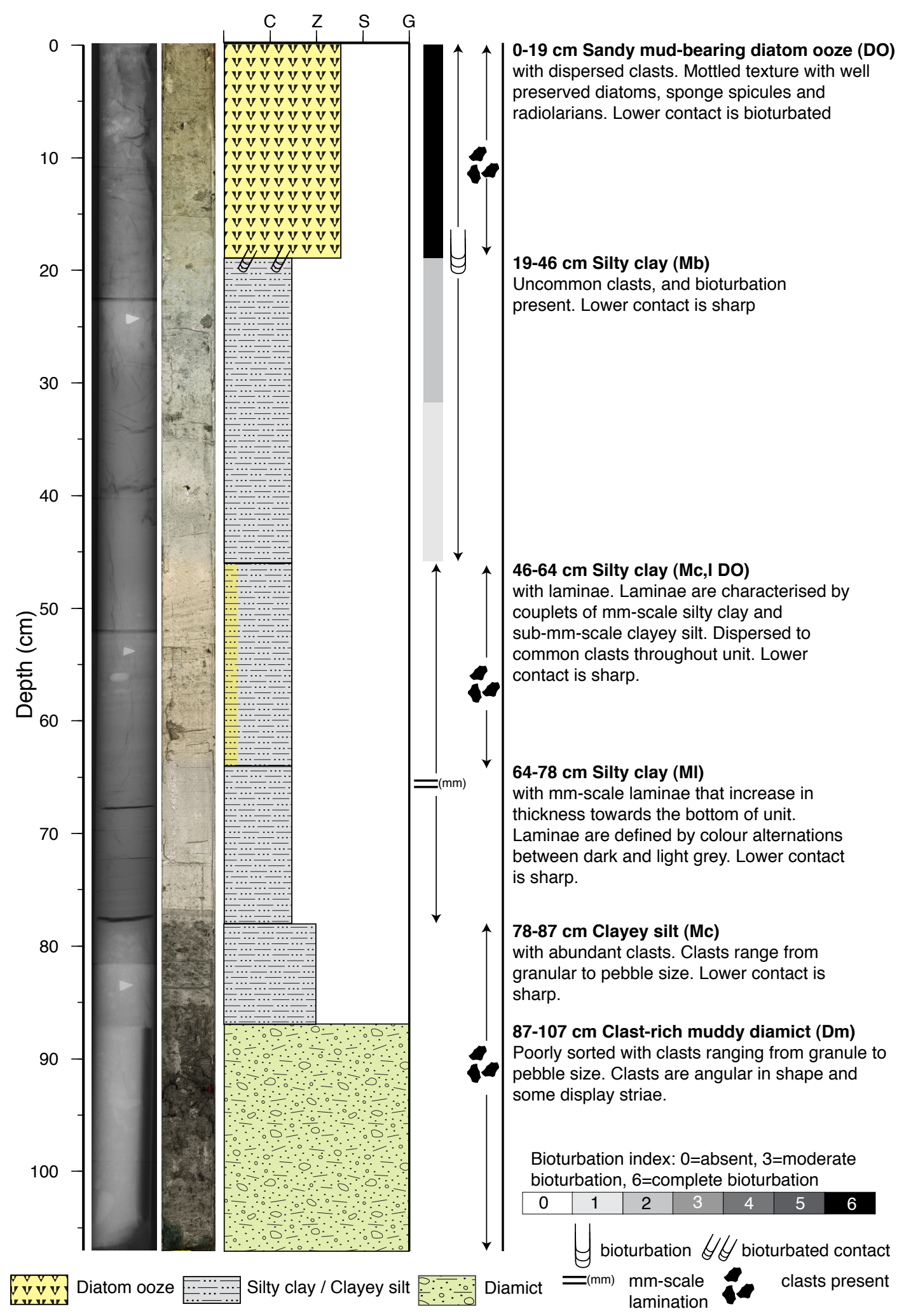

Figure 4.3: Stratigraphic column from core CHGC-08, including image from the core, X-ray, graphic lithology log and description of the units. Clast content is identified in the X-ray images rather than the split core image, where some "clastlike" features are due to core splitting disturbance (e.g. $25 \mathrm{~cm})$. 

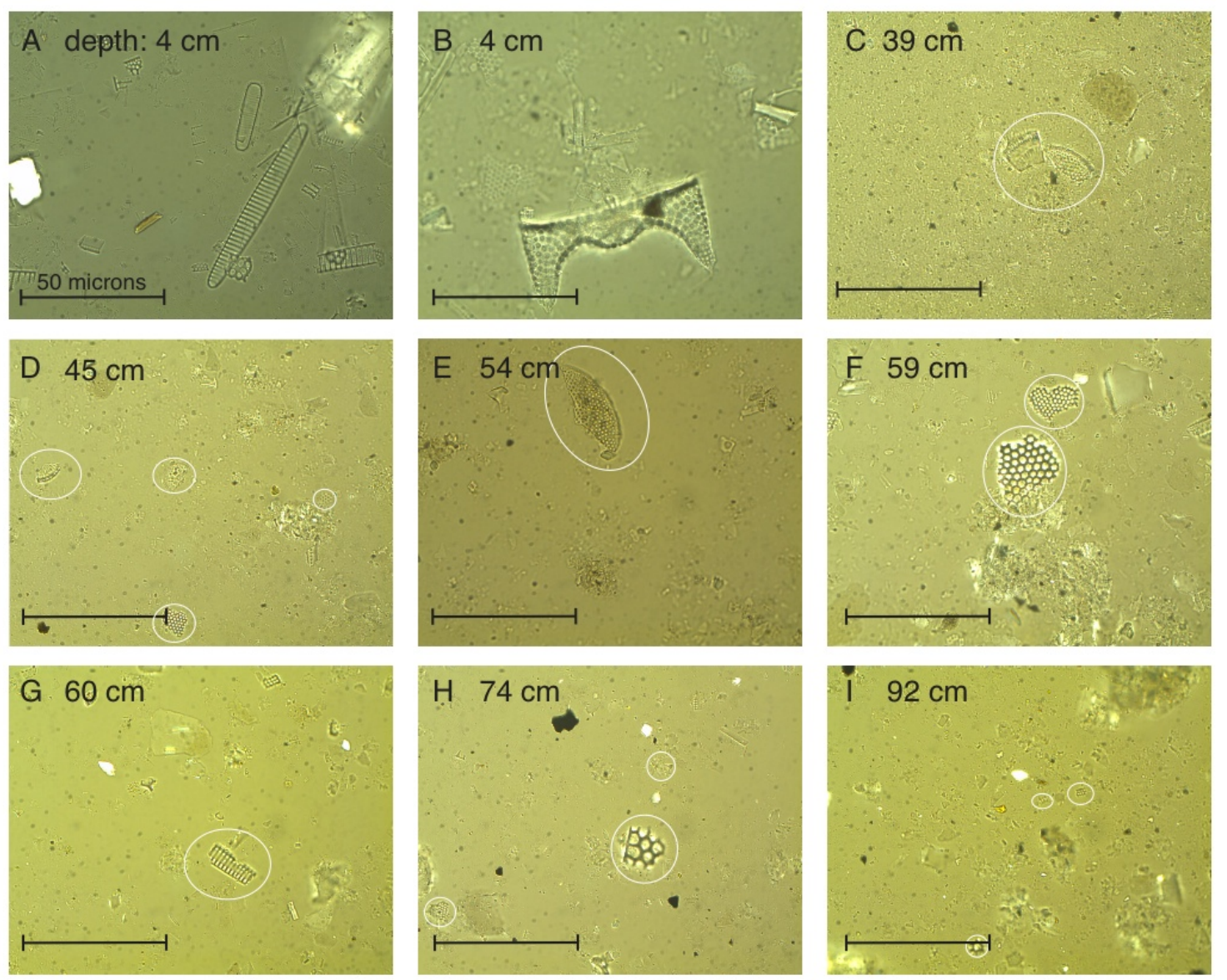

Figure 4.4: Photographs of diatoms at various depths in CHGC-08. A (4 cm) Fragilariopsis curta and F. obliquecostata; B $(4 \mathrm{~cm})$ Eucampia antarctica; C (39 $\mathrm{cm})$ fragments of centric diatoms; D (45 cm) fragments of centric diatoms; E (54 $\mathrm{cm})$ fragments of a centric diatom; F $(59 \mathrm{~cm})$ fragments of centric diatoms; $\mathrm{G}(60 \mathrm{~cm})$ fragment of a pennate diatoms, probably Fragilariopsis sp.; $\mathrm{H}(74 \mathrm{~cm})$ fragment of a centric diatom; I $(92 \mathrm{~cm})$ fragments of diatoms. Scale bar is 50 microns. 
A. $1 \mathrm{~cm}$; Facies DO

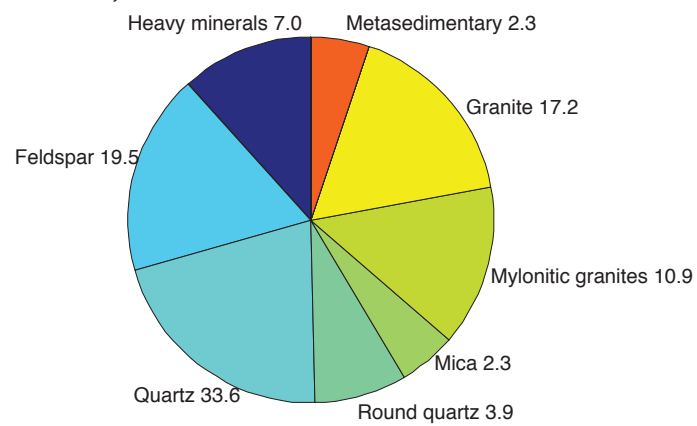

C. $8 \mathrm{~cm}$; Facies DO
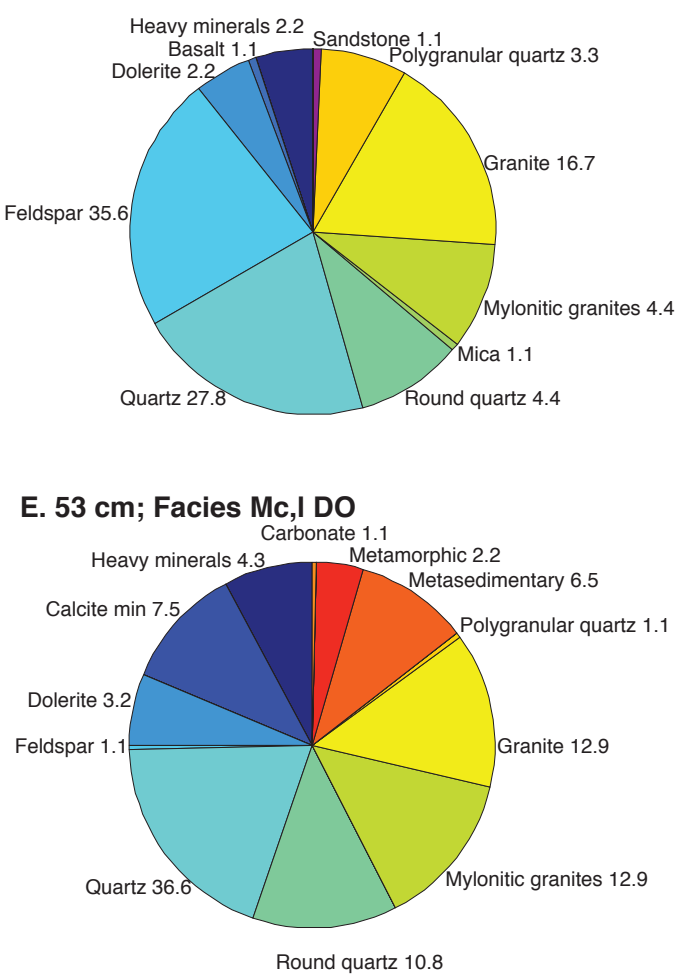

G. 80 cm; Facies Mg

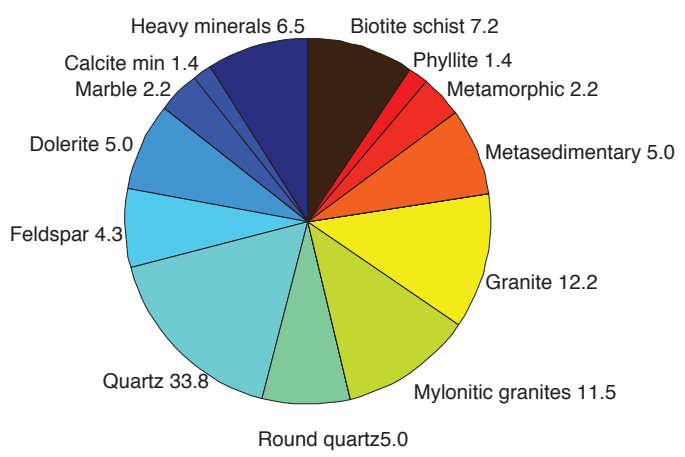

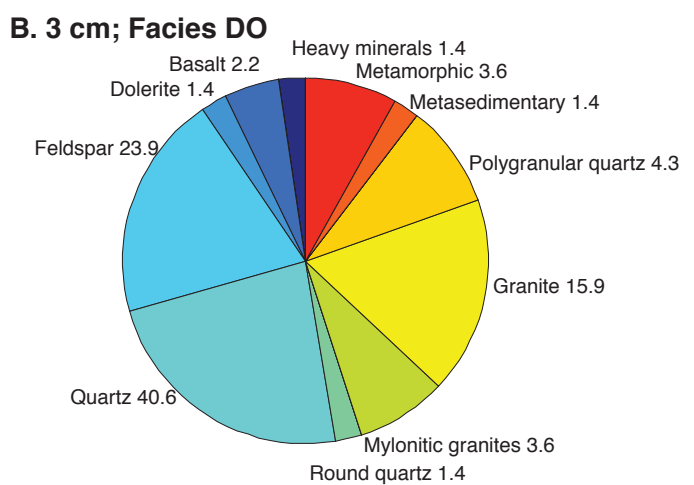
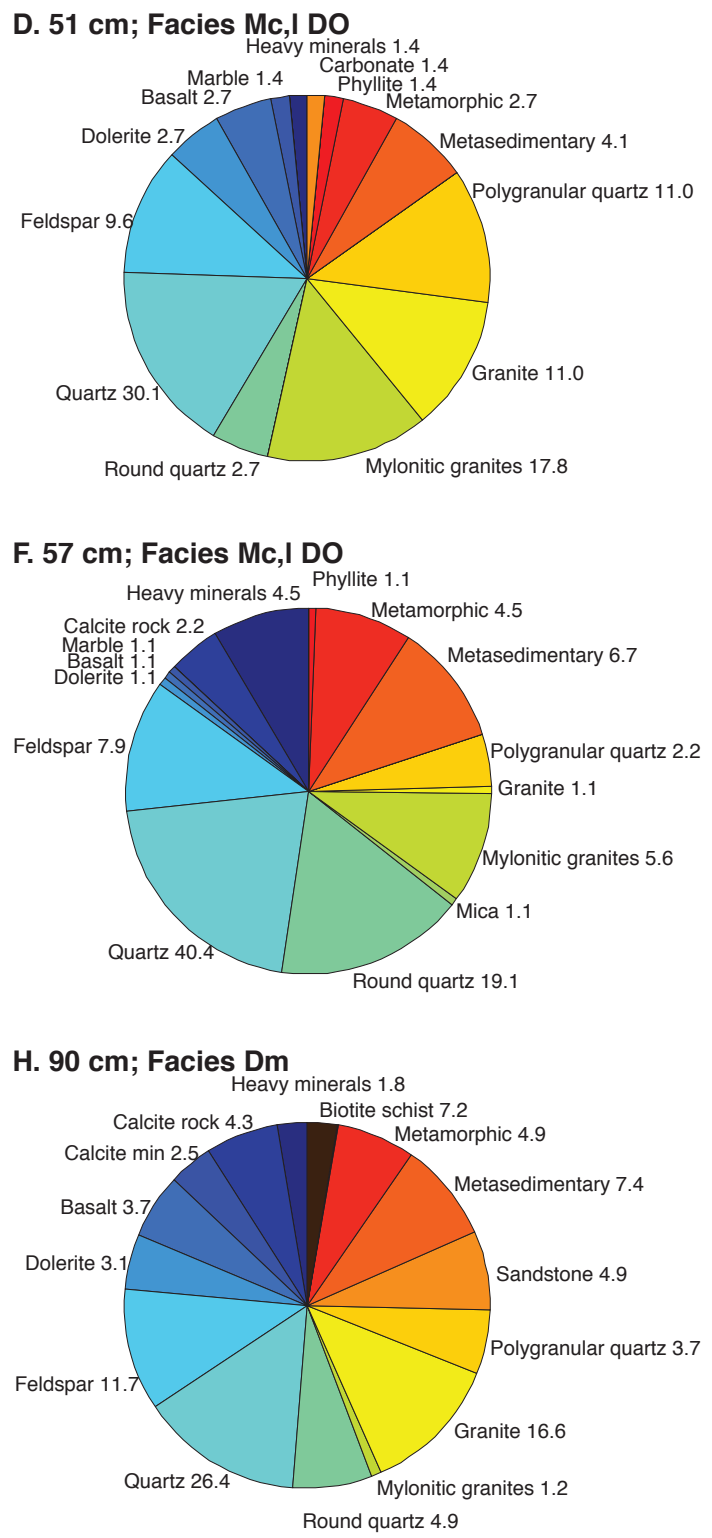

Figure 4.5: Pie charts on petrology data from CHGC-08. A: $1 \mathrm{~cm} ; \mathrm{B}: 3 \mathrm{~cm}$; C: 8 cm; D. $51 \mathrm{~cm}$; E: $53 \mathrm{~cm}$; F: $57 \mathrm{~cm}$; G: $80 \mathrm{~cm}$; H: $90 \mathrm{~cm}$. Till pellet counts are not shown in pie charts, values are presented in Appendix B (Table B.9). Pie slice area is proportional to $\log (\%)$, this means relative order of size is preserved and units $<1 \%$ are omitted. 

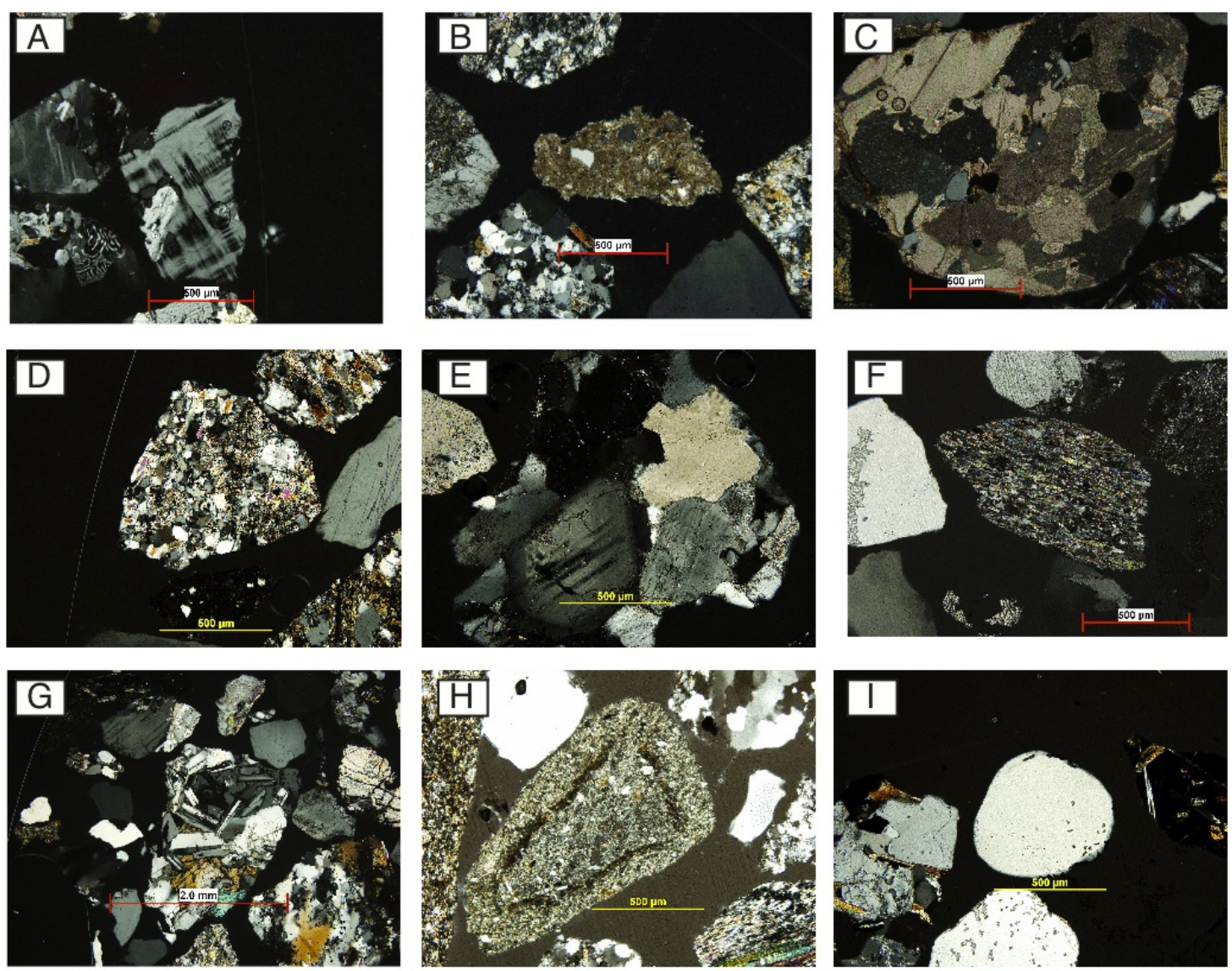

Figure 4.6: Photographs of grains in CHGC-08. A: Microcline. B: Diamict rock fragment from $51 \mathrm{~cm}$. C: Marble. D: Weathered mylonitic granite. E: Granite. F: Medium grade metamorphic. G: Ferrar Dolerite. H: Diamict rock fragment from 90 cm. I: Rounded quartz. 


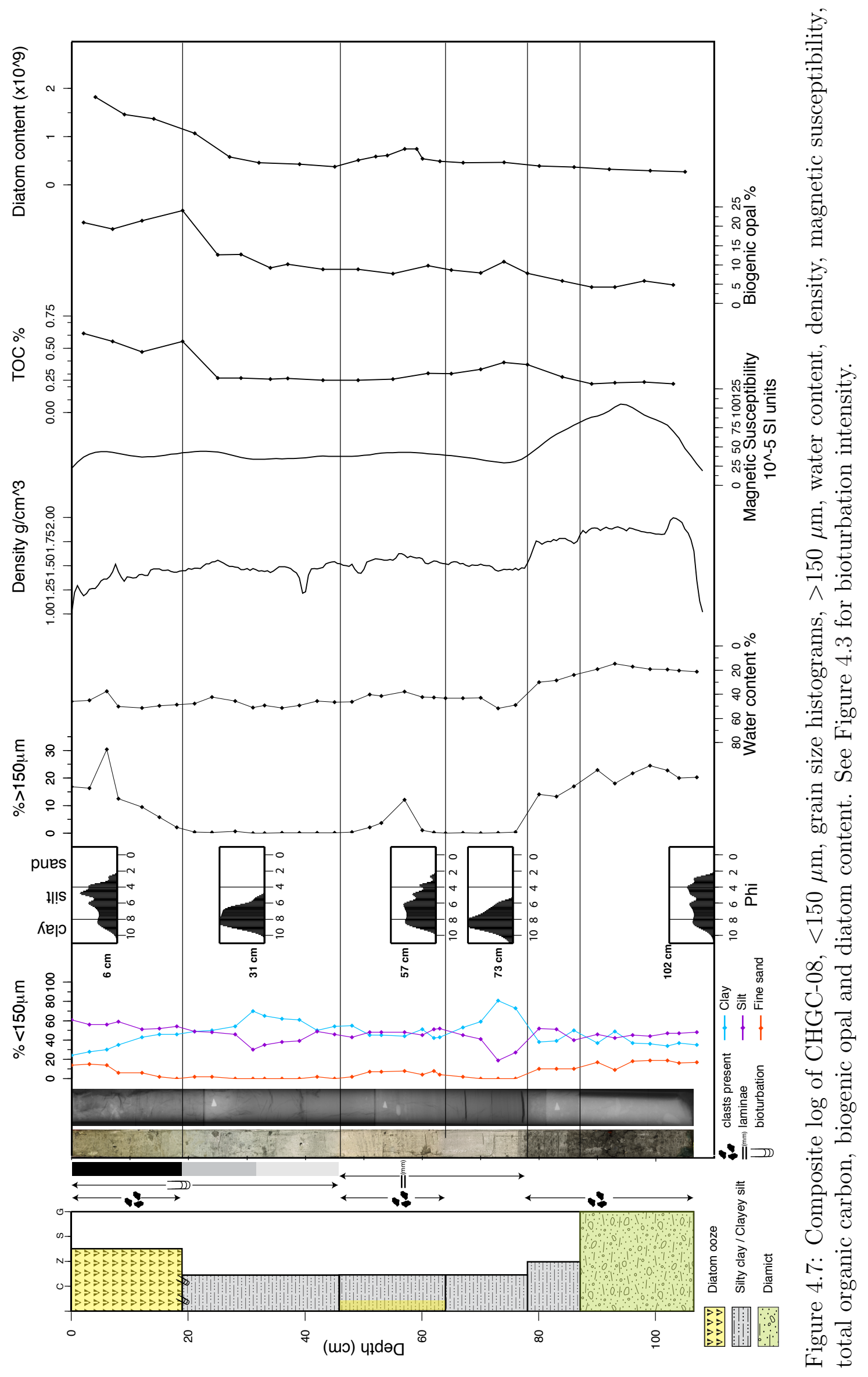




\subsection{Chronology}

Twenty AIO bulk sediment ${ }^{14} \mathrm{C}$ dates from CHGC-08 and 14 range from 10-35 and 11-32 ${ }^{14} \mathrm{C}$ kyr, respectively (Table 4.1). The core top age from CHGCG-14 (taken at $0-2 \mathrm{~cm}$ ) is $11,284{ }^{14} \mathrm{C} \mathrm{yr}$, and is significantly older than the core top ages presented in Andrews et al. (1999). The total organic carbon \% (TOC) at $3 \mathrm{~cm}$ in CHGC-14 is $0.568 \%$ and is within the range of the TOC \% from Andrews et al. (1999). They suggest there is a relationship between the ${ }^{14} \mathrm{C}$ age and the percentage of TOC in the sample. However, the dates from Coulman High are markedly older, probably due to a combination of reworking of sediment and the old reservoir age in the Ross Sea. The ${ }^{14} \mathrm{C}$ ages in both CHGC-08 and 14 are not in stratigraphic order, with reversals present in all units (Figure 4.8; Table 4.1). The top ages in the diatom ooze range from $10-16{ }^{14} \mathrm{C}$ ka, although, these ages are expected as it is a condensed section with a low sedimentation rate and there is mixing of the sediment due to bioturbation, which explains that the ages are not in stratigraphic order. The presence of such a condensed section with means that the core top method cannot be applied.

The two radiocarbon ages from foraminifera shells are $8,726 \pm 63{ }^{14} \mathrm{C}$ yr from $N$. pachyderma, and $8,892 \pm 85{ }^{14} \mathrm{C}$ yr from benthic foraminifera. By assuming a reservoir age of 1200 years, these dates can be corrected, and these ages allow the comparison with pre-existing studies due to the large errors associated with the reservoir age calibration (Table 4.2) The ages have been corrected and calibrated using the CALIB09 program, with a reservoir age of 1200 years (Table 4.2; Reimer et al., 2009). 
Table 4.1: Bulk sediment ${ }^{14} \mathrm{C}$ chronology for cores CHGC-08 (Site 2) and CHGC-14 (Site 3).

\begin{tabular}{cccccccc} 
Core & Depth $\mathbf{( c m})$ & Age BP & error & $\delta{ }^{13} \mathbf{C}$ & $\delta{ }^{14} \mathbf{C}$ & $\Delta{ }^{14} \mathbf{C}$ & \% modern \\
\hline \hline CHGC-08 & $1.5-2.5$ & 13573 & \pm 50 & -37.2 & -821.3 & -816.8 & 18.32 \\
CHGC-08 & $10-11$ & 10074 & \pm 35 & -25.2 & -716.9 & 716.7 & 28.33 \\
CHGC-08 & $17-18$ & 16018 & \pm 55 & -24.9 & -864.8 & 864 & 13.51 \\
CHGC-08 & $23-24$ & 25100 & \pm 150 & -33.7 & -957.2 & -956.4 & 4.36 \\
CHGC-08 & $27-28$ & 31390 & \pm 310 & -22.6 & -979.9 & -980 & 2 \\
CHGC-08 & $32-33$ & 28870 & \pm 230 & -21.3 & -972.5 & 972.7 & 2.73 \\
CHGC-08 & $46-47$ & 32190 & \pm 350 & -22.1 & -981.9 & -982 & 1.8 \\
CHGC-08 & $59-60$ & 29130 & \pm 240 & -26 & -973.6 & 973.6 & 2.64 \\
CHGC-08 & $71-72$ & 33210 & \pm 390 & -22.2 & -984 & -984.1 & 1.59 \\
CHGC-08 & $75-76$ & 26240 & \pm 170 & -23.9 & -962 & -962.1 & 3.79 \\
CHGC-08 & $79-80$ & 35250 & \pm 510 & -30.2 & -987.8 & -987.7 & 1.23 \\
CHGC-08 & $88-89$ & 26210 & \pm 180 & -22.4 & -961.8 & -962 & 3.8 \\
CHGC-08 & $101-102$ & 33050 & \pm 390 & -34.3 & -984.1 & -983.8 & 1.61 \\
\hline CHGC-14 & $0-2$ & 11284 & \pm 40 & -24.7 & -756.2 & -756.4 & 24.36 \\
CHGC-14 & 1921 & 11896 & \pm 40 & -23.3 & -773.5 & -774 & 22.58 \\
CHGC-14 & $26-28$ & 18338 & \pm 70 & -23.1 & -898.4 & -898.8 & 10.12 \\
CHGC-14 & $37-39$ & 27620 & \pm 200 & -21 & 967.8 & -968.1 & 3.19 \\
CHGC-14 & $46-46$ & 30530 & \pm 280 & -21.8 & -977.7 & -977.8 & 2.22 \\
CHGC-14 & $72-74$ & 32540 & \pm 360 & -21.4 & -982.6 & -982.7 & 1.73 \\
CHGC-14 & $90-92$ & 30190 & \pm 270 & -22.9 & -976.8 & -976.9 & 2.31
\end{tabular}

Table 4.2: Radiocarbon ages on foraminifera. Uncorrected age, corrected age, with reservoir age of 1200 years, and calibrated age from Reimer et al. (2009) with reservoir age of 1200 years.

\begin{tabular}{lllll} 
Depth $(\mathrm{cm})$ & Type & $\begin{array}{l}\text { uncorrected } \\
(14 \mathrm{C} \text { yr BP })\end{array}$ & $\begin{array}{l}\text { corrected age } \\
(14 \mathrm{C} \text { yr BP })\end{array}$ & $\begin{array}{l}\text { calibrated age } \\
(\text { cal BP })\end{array}$ \\
\hline \hline $50-52$ & $\begin{array}{l}\text { Neogloboquadrina } \\
\text { pachyderma }\end{array}$ & $8726 \pm 63$ & 7526 & $8391 \pm 55$ \\
& Benthic foraminifera & $8892 \pm 85$ & 7692 & $8555 \pm 75$
\end{tabular}




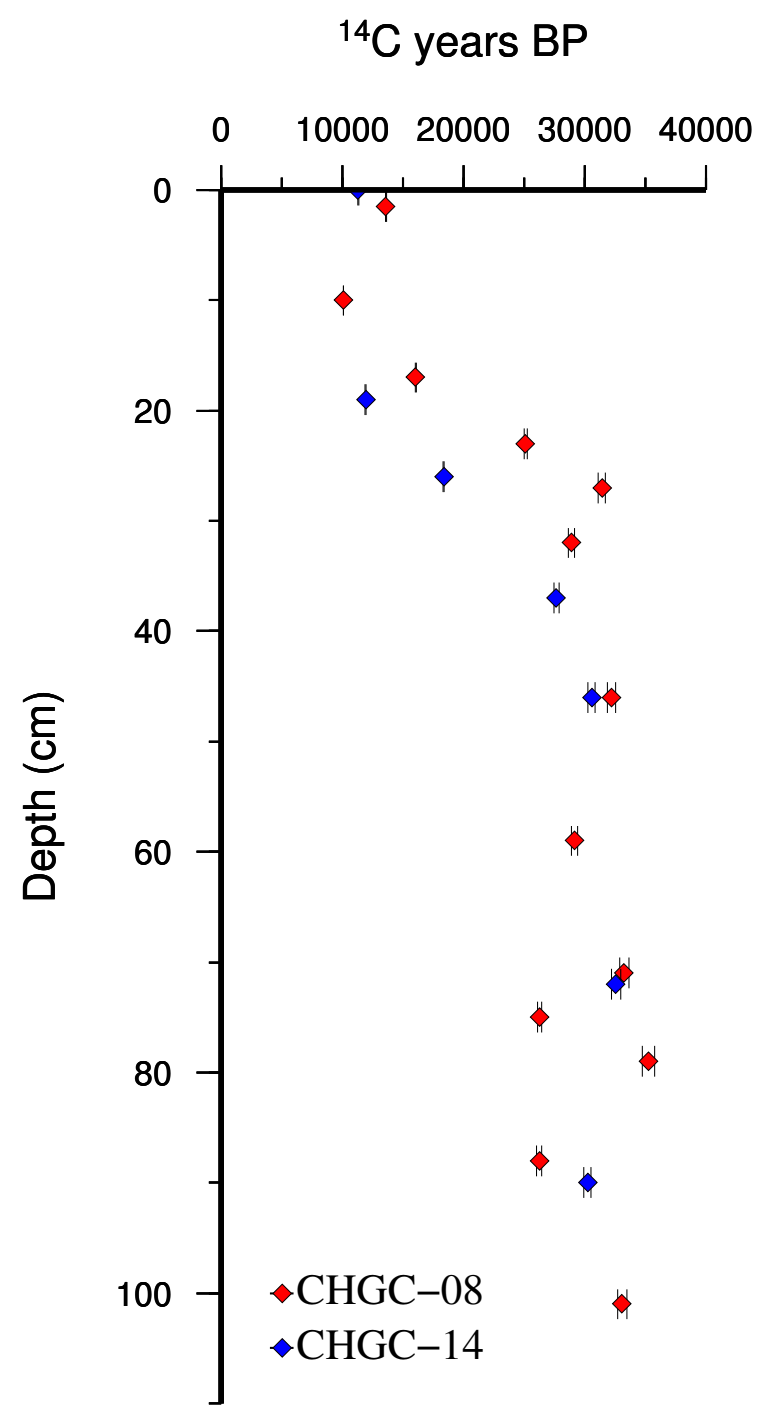

Figure 4.8: ${ }^{14} \mathrm{C}$ chronology on core CHGC-08 (red, Site 2) and CHGC-14 (blue, Site 3) from bulk sediment. 


\section{Chapter 5}

\section{Discussion}

\subsection{Depositional model}

The facies characterised in the short sediment cores are interpreted to represent distinct depositional environments. In this section, depositional environments are identified through comparison of the facies discussed in the previous chapter with pre-existing models of subglacial and glacimarine deposition (e.g. Domack et al., 1999; Hemer and Harris, 2003; McKay et al., 2008). Differences in the textural and compositional nature of each facies, as well as vertical stacking patterns of the facies, are used to distinguish between subglacial/glacimarine deposition versus reworking by mass flow processes. From the four different sites, cores collected from Site 2 displayed the most coherent stratigraphy; massive diamict representing a subglacial environment, overlain by different mud facies denoting the retreat of grounded ice and the calving line, followed by diatom ooze indicating open marine conditions.

\subsubsection{Subglacial}

The base of the facies succession consists of a massive diamict, which can be deposited in a variety of environments, including iceberg scouring, volcanogenic debris flows, glacimarine, or subglacially by the overriding of grounded ice (Dowdeswell et al., 1994; Domack et al., 1999; Anderson, 1999; Hambrey and McKelvey, 2000). Iceberg scouring can be discounted as a mechanism at Coulman High as the water depth is $>800 \mathrm{~m}$ at this location, and iceberg furrows are only observed in water depths up to $575 \mathrm{~m}$ in the Ross Sea using swath bathymetry (Shipp et al., 2002). The process of a volcanogenic debris flow derived from Ross Island producing the diamict can also be rejected, as the provenance of the clasts within the diamict lacks a significant basaltic component characteristic of Ross Island, a 3,794 m high poly- 
genic stratovolcano composed of phonolites, tephriphonolites, trachytes and basalts (Esser et al., 2004).

However, deposition by glacimarine debris flow is harder to discount, as evidence of shearing or loading by grounded ice is non existent, only the upper $47 \mathrm{~cm}$ of this facies was recovered, consequently the basal contact was not observed. Generally, basal contacts produce the most credible evidence for subglacial deposition by allowing assessment of glaciotectonic deformation of the underlying facies (Fielding et al., 2000; Dunbar et al., 2008; McKay et al., 2009; McKay et al., 2012b). The degree of compaction is a further characteristic that has been used to identify deposition beneath grounded ice, whereby loading of an overriding ice sheet results in shear strength exceeding $\geq 1 \mathrm{~kg} \mathrm{~cm}^{-2}$ (e.g. Anderson et al., 1980; Ó Cofaigh et al., 2005).

The diamicts recovered in this study were all under consolidated. Notwithstanding low shear strength does not rule out subglacial deposition as diamicts deposited beneath relatively fast flowing ice inherit different characteristics. Diamicts deposited underneath ice streams are less indurated, are finer grained (Tulaczyk et al., 1998; Ó Cofaigh et al., 2005) and have a porosity of 40\% (Alley et al., 1986). The fine grained sediment enables the build up of high subglacial pore water pressures, which in turn prohibits the coarse material from communition (Tulaczyk et al., 1998). As Coulman High lies in the path of a paleo-ice stream (Hughes, 1977), it is to be expected for the diamict to be under consolidated. The sand-silt-clay size distribution of the tills underlying the Whillians Ice Stream show a higher sand content compared to the Coulman High diamict, which lies in the range of the Ross Sea tills (Figure 5.1; Anderson et al., 1980), which is suggestive of a lack of current winnowing or water sorting by glacimarine processes. The fine grained material seen at Coulman High could be due to the reworking of Miocene diamictites and mud-rich sediments in the Ross Sea due to a high degree of glacial erosion and communition (Anderson et al., 1980). Additionally, the coarser sediment seen beneath the Whillians Ice Stream could represent the closer proximity of the source material.

The provenance of clasts within the diamict provides the most compelling evidence of subglacial or grounding line proximal glacimarine deposition. Biotite schists and marbles, along with rounded quartz, meta-sedimentary and granite grains all occur in significant abundance in the massive diamict (Figure 4.5). All of these lithologies can be tied to three rock groups found at the mouth of the Byrd Glacier, including the Byrd Group, Granite Harbour Intrusive Complex and the Beacon Group (Crad- 
dock, 1972). Notably, only the Byrd Group contains outcrops of both scapolite marbles and biotite schists (Craddock, 1972) which occur in the massive diamicts (Figure 4.6). The likely Byrd Glacier provenance of these clasts provides evidence that the diamicts were transported to the core site within the subglacial bed load of an ice sheet coming from the Byrd Glacier region, which is consistent with the interpretation of Licht et al. (2005) using a similar methodology. The pebbles are both facetted and exhibit striae, which is also suggestive of subglacial transport. In addition, the low diatom content $\left(2.7 \times 10^{8} \mathrm{v} / \mathrm{g}\right)$ is mainly comprised of fragmented centric diatom frustules (Figure 4.4), which is a probable consequence of being subjected to high degrees of shearing by subglacial transport and deformation (Scherer et al., 2004).

The above evidence indicates that these diamicts may have been deposited as a subglacial traction till, or as a grounding line proximal glacimarine deposit, where the sediment accumulated immediately adjacent to the grounding line and was postdepositionally reworked by mass flow processes (Figure 5.3A; Kurtz and Anderson, 1979; Anderson, 1999). The later scenario still allows for a glacial retreat history to be determined from Site 2 cores, as the diamict would represent the immediate 'post-lift off of grounded ice' phase of ice sheet retreat since the LGM.

\subsubsection{Sub-ice shelf, proximal to the grounding line}

Overlying the massive diamict is a mud with abundant clasts (Facies Mc). The clasts range from granular to pebble size, and include till pellets which are well rounded (Figure 4.6). These intraclasts are interpreted to be formed within a deforming bed (van der Meer, 1993) and then consequently transferred into the ice shelf by the flowing ice, which through basal melting were deposited at the site (McKay et al., 2012b). The rise in Total Organic Carbon in this unit compared to the underlying diamict (increase of $0.1 \%$; Table B.1) suggests a glacimarine depositional environment (Domack et al., 1999). Additionally, there is a rise in water content (5\%; Figure 4.7), suggestive lesser compaction compared to the diamict (Domack et al., 1999).

The grain size distribution has a lower sand and higher silt content, however the clay content is fairly similar compared to the massive diamict (Figure 5.1). This could represent deposition by a melt-out of basal debris with little water sorting. These characteristics of this facies are similar to the granulated facies described by Domack et al. (1999), who interpreted this facies to be deposited proximal to the 


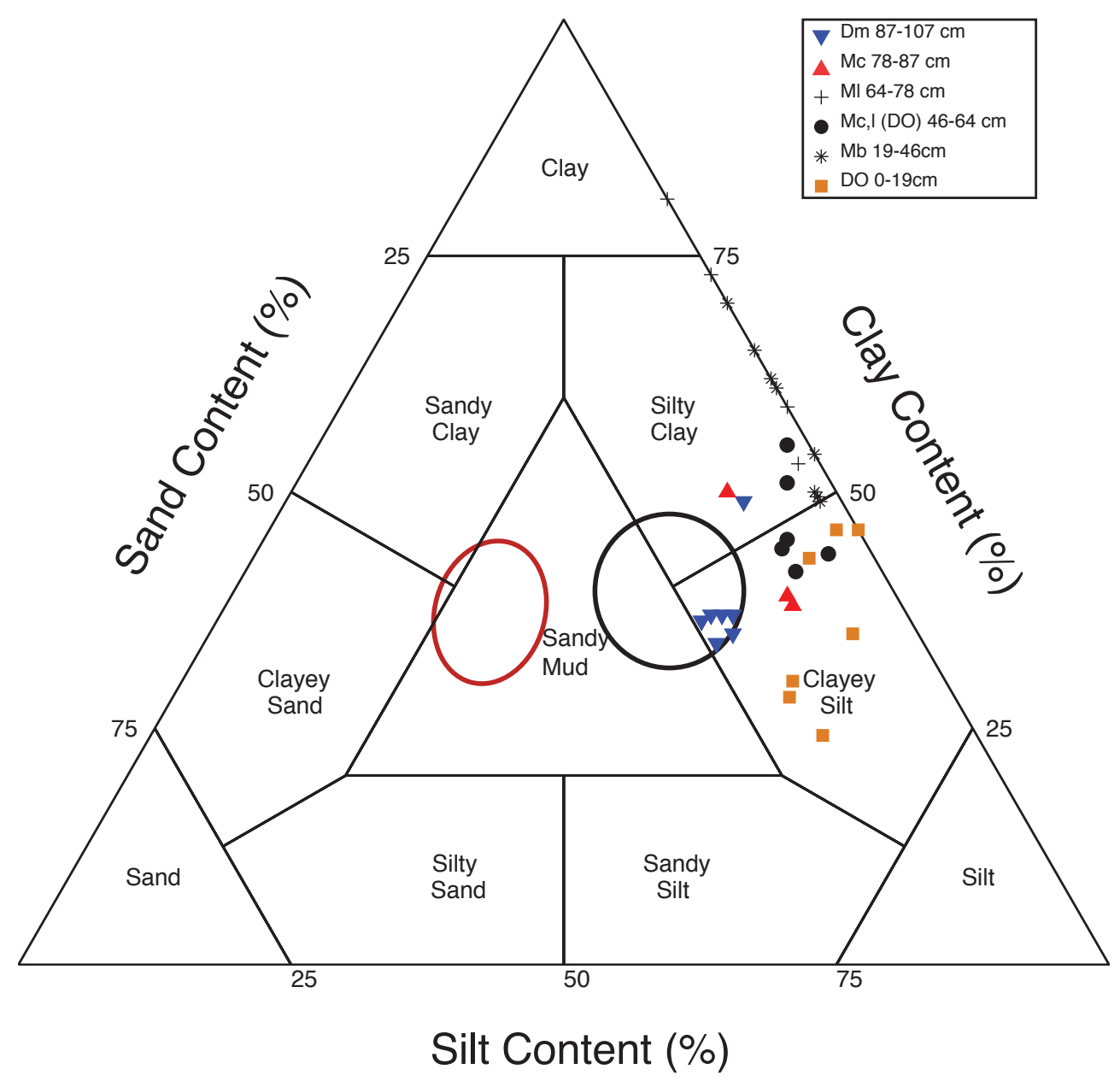

Figure 5.1: Grain size distribution of CHGC-08, Shephard diagram showing textural classification. Black circle is $1 \sigma$ error from mean Ross Sea tills (Anderson et al., 1980), red ellipse represents Willians Ice Stream till (Tulaczyk et al., 1998).

grounding line, representing the ice sheet lift-off, where the environment is transitioning into an ice shelf environment. This evaluation aids the interpretation that the Coulman High cores contain a record of the retreat of the grounded ice in the Ross Embayment.

\subsubsection{Sub-ice shelf}

The unit overlying the granulated facies is a well-sorted clay with mm-scale laminae (Facies Ml). The laminated facies is discriminated from the granulated facies due to the lack of coarse material. This unit is dominated by clay (Figure 5.1), where the mm-scale laminations are defined both by colour and texture (Figure 5.2). The laminae are comparable to the laminae described by Domack (1990) on cores collected at the Antarctic Peninsula. The regularity of the laminae and the lack of 


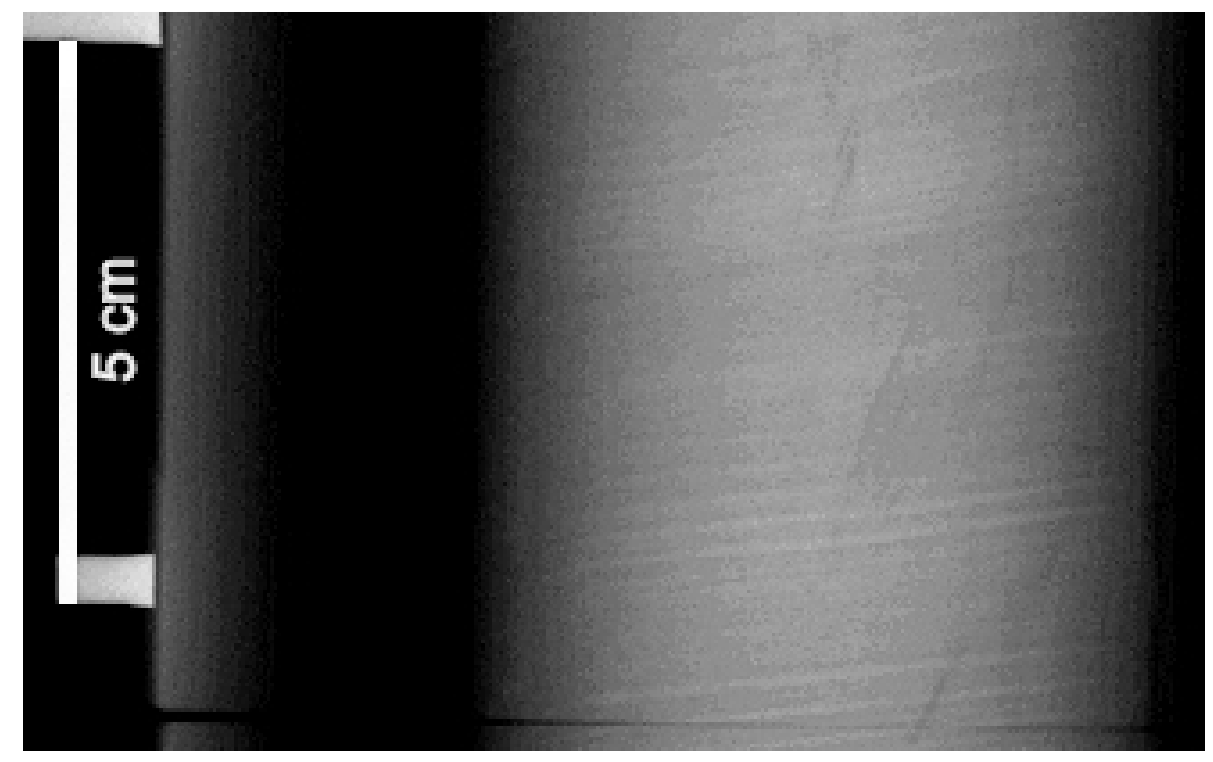

Figure 5.2: CHGC-11 (Site 2) X-ray image zoomed in on laminations, 45 laminae are present within in the $5 \mathrm{~cm}$ displayed.

load structures and coarse material suggest that they are not created by turbidity currents (Ó Cofaigh et al., 2001). Instead, they are the possible consequence of traction currents, that could be formed by the tidal pumping of the grounding zone, where fine material settles out over the core site (Domack et al., 1999). If the sea floor has no bathymetric features and is relatively flat, the grounding zone can easily migrate back and forth, driven by the rise and fall of the tidal cycle. The current tidal height variations at the grounding zone at the Siple Coast is $\sim 1 \mathrm{~m}$ (Anandakrishnan and Alley, 1997). Alternatively, these currents are caused by enhanced current strength close to the grounding zone in a reduced cavity underneath the ice shelf (MacAyeal, 1984). Sortable silt measurements (mean grain size in the 10-63 $\mu \mathrm{m}$ fraction) indicate paleo-current strength (McCave et al., 1995). During times with stronger currents, winnowing of the fine sediments (e.g. clay; $\leq 8 \mu \mathrm{m}$ ) occurs, and a peak would be present in the silt/fine sand fraction. In the Facies Ml, the sortable silt shows a decrease from 74 to $64 \mathrm{~cm}$, indicating a progressive reduction in current strength (Figure B.15; McCave et al., 1995), which could be due to the retreat of the grounding line from the locality of the drill site, and therefore reduced traction currents formed by either of the above two scenarios (Figure 5.3B).

\section{Sub-ice shelf - open marine}

The laminated mud is overlain by a laminated mud with clasts present (Facies Mc,1 DO). The diatom content increases from $4.6 \times 10^{8} \mathrm{v} / \mathrm{g}$ in Facies Ml to $7.5 \times 10^{8} \mathrm{v} / \mathrm{g}$ in Facies Mc,l (DO). Furthermore, the diatom fragments are qualitatively larger 
in this facies (Figure 4.4). The fine sediment fraction is not as well sorted as the underlying laminated mud (Figure 5.1). The coarse material is not derived from a debris flow from Ross Island, as there is not a basaltic signature. Instead, the grains are dominated by quartz, granite and mylonitic granite. One possibility is that this debris is from Granite Harbour, or further north along Scott Coast, and was brought to the site by icebergs, which is consistent with the petrology data (Figure 2.2). This increase in coarse material ( $>150 \mu \mathrm{m}$; Figure 4.7) occurs in conjunction with the presence of both planktic and benthic foraminifera. The combined presence of diatoms, clasts and foraminifera suggest that open water conditions were proximal to the core site. The lack of load structure in this facies excludes turbidity currents as the mechanism for the laminae (Ó Cofaigh et al., 2001). The laminae in this facies are likely to be formed by the same mechanism as in the underlying Facies $\mathrm{Ml}$ as they show the same structures and thickness. This would suggest that the grounding and calving line may have been in close proximity to one-another (Figure 5.3C).

\section{Sub-ice shelf}

The laminated mud is succeeded by a clay-dominated mud with bioturbation (Facies $\mathrm{Mb})$. The unit has no sand content, and a higher clay percentage than the underlying mud (Figure 5.1). At the bottom of this facies, the diatom content is lower than in the underlying facies $\left(0.37 \times 10^{9} \mathrm{v} / \mathrm{g}\right)$ and the fragments are smaller (Figure 4.4). However, both the percentage and fragment size increase towards the top of the unit $\left(1.0 \times 10^{9} \mathrm{v} / \mathrm{g}\right)$. The bioturbation is uncommon to moderate in the unit, but the presence of bioturbation indicates that the calving line is proximal (e.g. Hemer and Harris, 2003). The lack of coarse material and drop in diatom content suggests the site was more distal from open marine conditions than the underlying Facies Mc,l (DO). The succession of these facies suggest that the calving line stabilised as it got pinned to Ross Island.

\subsubsection{Open water}

Although all four sites are presently covered by the Ross Ice Shelf, the Coulman High sites is located directly beneath the position of several large calving events of tabular icebergs from the Ross Ice Shelf, with the most recent one occurring in May 2002 (e.g. Ferrigno et al., 2008; Lazzara et al., 2008). At all sites, the upper $10-30 \mathrm{~cm}$ consists of biosiliceous ooze with diatom contents of $>1.9 \times 10^{9} \mathrm{v} / \mathrm{g}$. The facies is also characterised by abundant sand to gravel material, and pervasive bioturbation. The majority of the clasts are feldspar (a quarter are microcline) and quartz, and granitic fragments (Figure 4.5). Even though diatoms can be advected 
underneath an ice shelf (Cunningham and Leventer, 1998), coarse sediment cannot be advected. The larger pebbles are more than 100 times larger than the mean size of the surrounding sediment (silt), which implies two different current speeds for the two sediment class sizes to be deposited at the same location (Bennett et al., 1994). The sea floor imagery shows that boulders are present, and these are too large to be moved by bottom currents (Barrett et al., 2005). This implies that the emplacement of the coarse material was either by melt out from the ice shelf or rain out of icebergs (i.e. ice rafted debris, IRD).

Satellite data shows that the Ross Ice Shelf experiences basal melting, with up to $2.8 \pm 1.0 \mathrm{~m} \mathrm{a}^{-1}$ within a kilometre of the calving front (Horgan et al., 2011). However, video footage of the ice hole at Coulman High shows that the ice shelf does not contain coarse sediment. Using an ice flow model, Dunbar et al. (2009) calculated that basal debris from the Terror Glacier on Ross Island that feeds the ice shelf, would melt out within a few kilometres from the glacier. This implies that the lithological material found in the diatom ooze was brought to the site by icebergs and that the diatom ooze was deposited in periodically open water.

\subsection{Chronology of post LGM glacial retreat in the Ross Embayment}

The facies succession discussed above is fully preserved in the site 2 cores (CHGC07; CHGC-08; CHGC-11) and allows for a retreat history of the grounding line of the LGM ice sheet in the Western Ross Embayment as well as the establishment of the modern day calving line of the Ross Ice Shelf in the region of Coulman High to be established. A chronology based on AMS radiocarbon dates on the acid insoluble organic matter in bulk sediment and from benthic and planktonic foraminifera in this study is compared here to pre-existing studies of sediment cores and geophysical studies of the seafloor in the Ross Sea.

Studies reconstructing the maximum ice extent in the Ross Sea during the LGM based on either the flow of the WAIS or founded on observations of the terrestrial record in combination with ice flow, suggest that grounded ice reached the continental shelf edge (Stuiver et al., 1981; Kellogg et al., 1996). The presence of ice-proximal glacimarine facies in sediment cores and geophysical data mapping the seafloor in the Western Ross Embayment, constrained the expanse of the grounded ice sheet to have reached Coulman Island $\left(74^{\circ} \mathrm{S}\right)$ between 26.5 and $19.5^{14} \mathrm{C}$ ka (Domack et al., 


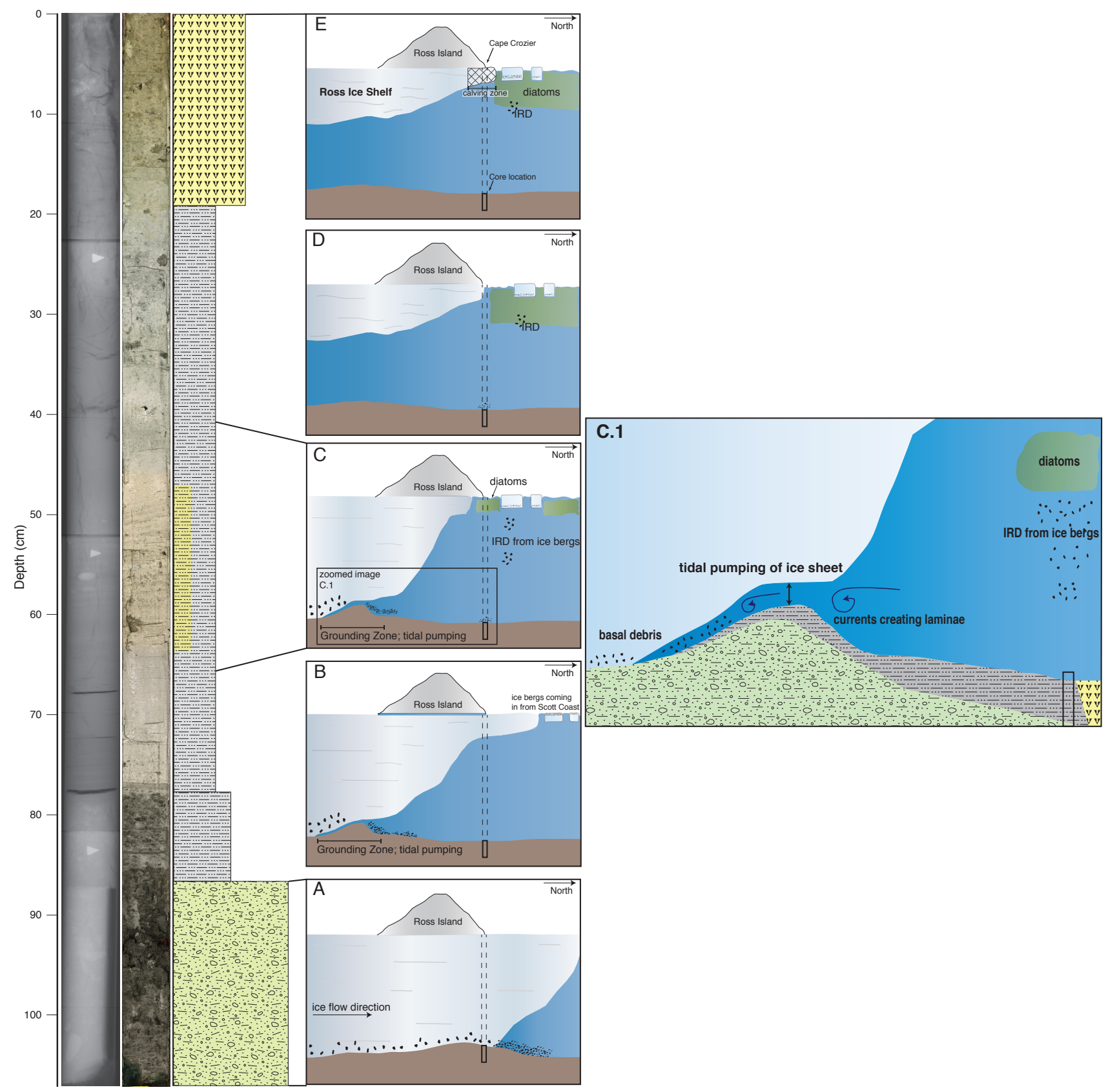

Figure 5.3: Cartoon depicting the retreat of the grounded ice at Coulman High. X-ray, core image, stratigraphic log, A. grounded ice situated over the core sites. B. the grounding line has retreated south, traction currents creating laminae in the mud. C. the grounding site is proximal to the site, and traction currents are driven by tidal pumping (e.g. Domack et al., 1999) or enhanced currents in a reduced cavity (MacAyeal, 1984). The calving line has retreated south of the core site, and foraminifera, diatoms and IRD are found at the site. D and E. As the grounding line retreated further south, the calving line is pinned to Ross Island, and occasionally, large tabular iceberg calve off, resulting in open water conditions at the site. Crosshatch depicts calving zone in E. 
1999; Licht et al., 1999; Shipp et al., 1999). Grounding zone wedges, which are created by the grounded ice depositing sediment at its terminus, have been mapped throughout the Ross Sea to determine how far north the ice progressed in individual basins and banks (e.g. Shipp et al., 1999; Shipp et al., 2002; Mosola and Anderson, 2006). To the east of the Coulman High site, in the Central and JOIDES Basin, geomorphic features on the seafloor have been grouped into different zones representing depositional and erosional processes (Shipp et al., 2002). The outer zones have been interpreted as the zone of deposition, by the advancement of the grounded ice (between $75-74^{\circ} \mathrm{S}$ ). The zone of transition is seen between 77 and $75^{\circ} \mathrm{S}$ where transverse moraines, grounding zone wedges and crevasse-fill wedges are present. Corrugation moraines (small, 1-2 m high, closely spaced, 40-100 m, and straightcrested corrugation) are observed in all zones (Figure 5.4; Shipp et al., 2002).

The corrugation moraines are thought to be deposited during the retreat of the ice sheet, where during a pause in the retreat, a sediment wedge accumulated at the outer limit of the ice. These are thought to be annual features, depicting a retreat rate of the grounded ice between 40 and $100 \mathrm{~m} \mathrm{a}^{-1}$ (Shipp et al., 2002). Conway et al. (1999) report a retreat rate of $84 \mathrm{~m} \mathrm{a}^{-1}$ of the grounded ice the Ross Sea, which agrees with the retreat rate of the ice shelf in the Western Ross Embayment calculated by Domack et al. (1999) of approximately $100 \mathrm{~m} \mathrm{a}^{-1}$. Chronology on sediment cores collected at the southern part of the Drygalski Trough showed that the calving line passed this location at $9,500{ }^{14} \mathrm{C}$ BP, and the ice shelf experienced a rapid retreat to Ross Island, where open water conditions where established at $8,861{ }^{14} \mathrm{C}$ BP (Figure 5.4; McKay et al., 2008).

As ice shelves act as a buttress to outlet glaciers draining ice sheets, physical obstacles such as Ross Island help to impede flow of an ice shelf resulting in a thickening of the ice shelf, and therefore act as a pinning point whereby the calving line remains at that location for a prolonged time (Rott et al., 1998). As the grounding line retreated south, past Ross Island after $\sim 10,000{ }^{14} \mathrm{C}$ yr BP, the ice shelf is hypothesized to have become pinned to Ross Island based on the lack of open water facies from Holocene cores collected beneath the McMurdo Ice Shelf (McKay et al., 2008).

In the Coulman High facies succession discussed above, the massive diamict is overlain by a coarse mud with abundant clasts (granulated facies) that is indicative of the retreat of the grounding line (e.g. Domack et al., 1999). As the grounding line 
retreated further south, the core location is situated in the 'null-zone'. The null-zone is defined by Domack et al. (1999) as being too distal from the grounding zone to allow for the deposition of sand or gravel derived from the grounding line, as well as being to distal from the open marine environment where micro-organisms are unlikely to have been advected that far underneath the ice shelf. The facies succession from the granulated mud is seen as the fining of the sediment; the 'null-zone' facies is represented by fine sand silts and clays, whereby the sand content drops to $0 \%$ as the grounding continues to retreat away from the core site (Domack et al., 1999). Although Domack et al. (1999) define this unit as structureless or slightly bioturbated, at Coulman High this facies is dominated by sub-mm-scale laminae (Figure 5.2). As discussed in Chapter 4, these laminae are likely formed in the presence of traction currents resulting from tidal pumping at the grounding zone. The clasts in the overlying laminated mud have a different provenance signature (Figure 4.5), and lack biotite schist grains. As there is no basaltic signature, a debris flow depositing the coarse sediment is unlikely.

At the same depth as the increase in both diatom content and coarse sediment, planktonic foraminifera are found, a sign of open water conditions at the site. These foraminifera are dated to be $8,800{ }^{14} \mathrm{C}$ yr $\mathrm{BP}$ (uncorrected and uncalibrated), and are the southern most marine age control on the retreat of the Ross Ice Shelf. The well preserved foraminifera, elevated diatom content and the increase in coarse sediment provides tangible evidence that there was open water over the site for a short period of time. Radiocarbon chronology done on bulk sediment near Ross Island suggest that by $8,900{ }^{14} \mathrm{C}$ yr BP open marine conditions were established north of Ross Island (McKay et al., 2008). Using a reservoir age of 1200 years on the foraminifera samples of Coulman High, gives an age of 7,600 ${ }^{14} \mathrm{C}$ yr BP. This is slightly younger than the age presented by McKay et al. (2008), however their ages were AIO dates on bulk sediments and likely had a component of reworked "old" carbon and were considered to be a maximum age. Calibrating the Coulman High age gives a date of $\sim 8,470$ yr cal BP (see Table 4.2 for the method). The widespread mid-Holocene climate optimum in Antarctica is dated between 11,500 and 9000, with an additional warm period in the Ross Sea between 7000-5000 yr using ice cores (Masson et al., 2000). The stabilisation of the ice shelf calving line at this time could either be due to the cooling following the mid-Holocene optimum, or it was the consequence of an internal stabilising mechanism whereby Ross Island acted as a pinning point. However there are large uncertainties regarding the timing of the mid-Holocene warm period (Indermühle et al., 1999), and combined with uncertainties in the reservoir 
age correction (and therefore the calibration of the radiocarbon ages) it is hard to distinguish between either hypothesis. In comparing the corrected age given above to existing dates from the Ross Sea suggests that as the grounding line retreated, the calving line closely followed this retreat.

Additionally, a third mechanism is possible. As the grounded ice retreated since the last glacial, the calving line was coupled to this retreat and was relatively close to the grounding line, compared to present day (distance is more than $1000 \mathrm{~km}$ between the calving and grounding line at the Siple Coast). As the grounding line retreated south of Ross Island at $10,000{ }^{14} \mathrm{C}$ yr BP (corrected; McKay et al., 2008), the calving line followed and it is possible that it retreated further south of Ross Island. The calving line of the Ross Ice Shelf is unlikely to have retreated as far south as Minna Bluff and then re-advanced during the Holocene, as the cores collected by McKay et al. (2008) show no evidence of the collapse of the McMurdo Ice Shelf during the Holocene; e.g. $60 \mathrm{~cm}$ of mud with a lack of IRD.

Therefore, despite the presence of open water during the early Holocene at the Coulman High, the core sites in this study suggest that Cape Crozier has acted as a pinning point throughout the Holocene. Initial open water conditions at 7,600 ${ }^{14} \mathrm{C}$ yr BP (corrected) may have been followed by a period of sub-ice shelf deposition in a calving line proximal location during the Early Holocene, as indicated by bioturbated muds overlying the diatom-bearing laminated with IRD. It is hard to quantify by how many kilometres the ice shelf re-advanced, since diatoms and other microorganisms can get advected underneath an ice shelf (Cunningham and Leventer, 1998). Following this, the condensed interval of $\sim 20 \mathrm{~cm}$ of diatom ooze with pervasive bioturbation and abundant sand/gravel represents the development of the modern calving line 'zone' over the drill site with the pinning point located near Cape Crozier. This is the location where the calving of large icebergs occurs, similar to the C-19 calving event where a $32 \mathrm{~km}$ wide iceberg calved off in 2002, to leave the site in periodically open water. Due to the condensed and heavily bioturbated nature of this interval, constraining the timing of the onset of these conditions is difficult to date. The AIO bulk sediment dates of both CHGC-08 and 14 in this unit range between $10-16 \mathrm{ka}{ }^{14} \mathrm{C} \mathrm{BP}$, and reversals are present. Due to the extensive bioturbation, this was anticipated.

The style of retreat of the Ross Ice Shelf since the LGM is hard to interpret solely using the cores collected at Coulman High. Conway et al. (1999) suggest a 'swinging 
gate' retreat, where the ice sheet stayed pinned at Roosevelt Island until 3,200 yr $\mathrm{BP}$ while retreating in the Western Ross Sea, and along Shackleton Coast. The banks present in the Ross Sea, like Crary, Ross, Pennell Bank and Ridges in the Eastern Ross Sea, separate the lower lying basin in the embayment. These lower lying troughs are hypothesised to represent the location of former paleo-ice streams (Hughes, 1977). Mosola and Anderson (2006) suggest that these paleo-ice streams in the Eastern Basin are an extension of the ice streams entering the Ross Ice Shelf at the Siple Coast. It is likely that the banks in the Ross Sea had a similar effect on the retreat of the grounded ice, as Ross Island has on the ice shelf, they acted as pinning points (Mosola and Anderson, 2006). As a result, the ice sheet may have retreated in an asynchronous manner within each of these basins.

The results from the Coulman High cores can not distinguish between either style of retreat as proposed by Conway et al. (1999) or Mosola and Anderson (2006), but provide an additional data point from which future studies can build on to test these hypotheses. However, the study can shed additional insight into the rate of retreat of the ice shelf and ice sheet grounding line. Domack et al. (1999) calculated a retreat rate of $100 \mathrm{~m} \mathrm{a}^{-1}$ of the ice shelf calving line using a core located in Drygalski Trough (100 km south of Coulman Island; NBP 95-01 KC 37) to a core location in Granite Harbour (NBP 95-01 PC 26).

Shipp et al. (2002) used the retreat of Domack et al. (1999) and Conway et al. (1999) to suggest that the grounding line retreated between 40 to $100 \mathrm{~m} \mathrm{a}^{-1}$, and they interpreted the corrugation moraines observed in the Ross Sea to be annual features of the grounded ice retreating. However, the corrugation moraines are in the JOIDES and Central Basin, which is adjacent to the basin Domack et al. (1999) calculated the ice shelf retreat. The similar retreat rates calculated in both basins suggest that they may have retreated simultaneously. Using the same latitude of core NBP95-01 KC 37, with a corrected age of $10,500{ }^{14} \mathrm{C}$ yr BP, calculating the rate of retreat of the calving line to the Coulman High site using the corrected (uncalibrated) age of $7,700^{14} \mathrm{C}$ yr BP, results in a retreat rate of $118 \mathrm{~m} \mathrm{a}^{-1}$ (Figure 5.4). This is highly consistent with the retreat rate by Domack et al. (1999) and and the corrugation moraines from Shipp et al. (2002).

Future work and more chronology might constrain the style and rate of retreat, and determine whether Ross Ice Shelf is sensitive to decadel/millenial climate change, or if large calving events, like the one around $7,700{ }^{14} \mathrm{C}$ yr BP, are part of the natural 
behaviour of the world's largest ice shelf.
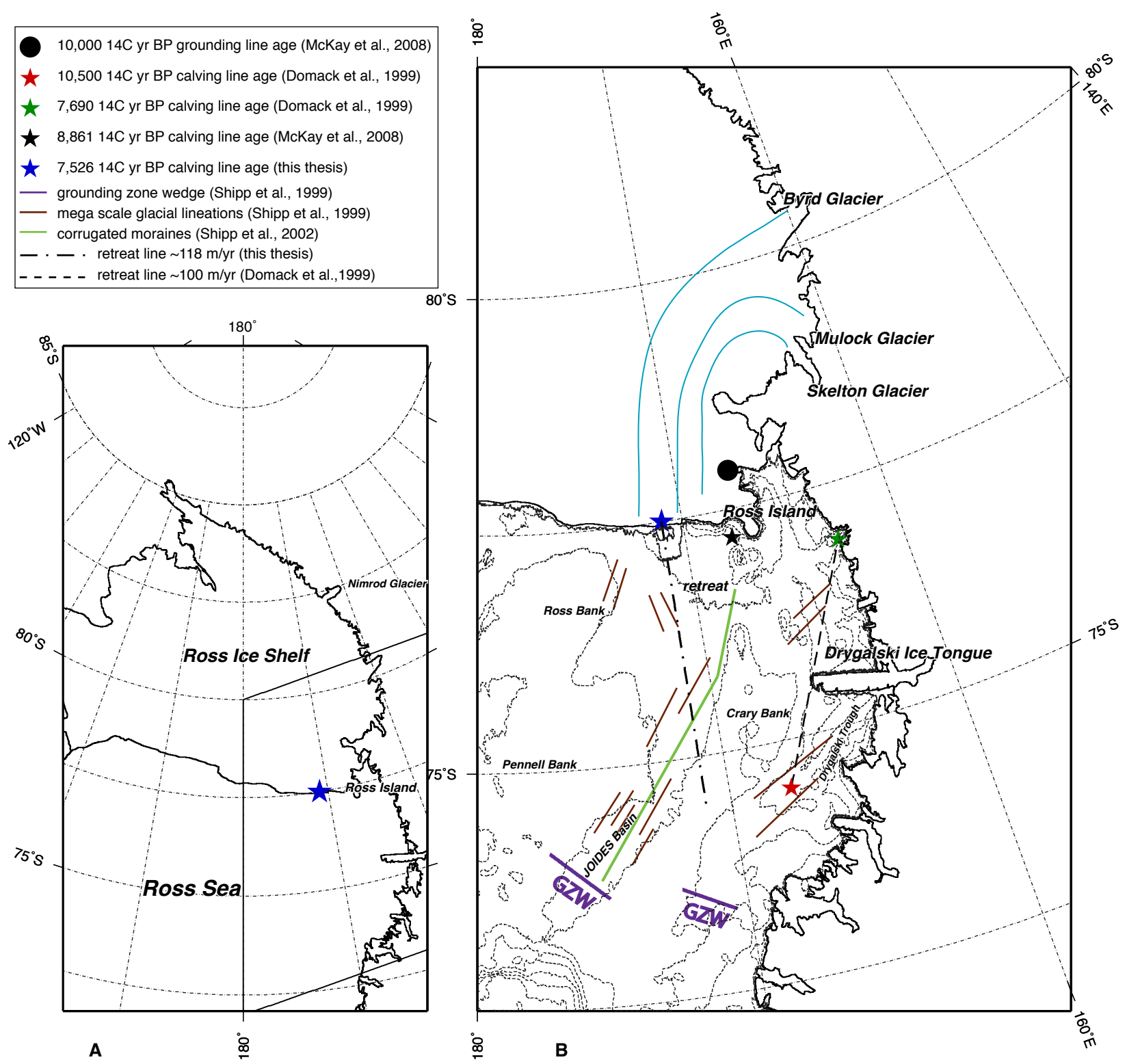

A

$\stackrel{\circ}{\circ}$

Figure 5.4: Map of cores site and retreat of the ice shelf, comparing this study with pre-existing shallow geophysical studies (Shipp et al., 1999, 2002) and studies on sediment cores (Domack et al., 1999; McKay et al., 2008). Present-day ice flow lines depicted in light blue. Bathymetric data from IOC and IHO (2003). 


\section{Chapter 6}

\section{Conclusions and future work}

The main conclusions of this study are:

- The sediment cores collected at Coulman High show a similar vertical succession of facies observed in previous studies done in the Ross Sea that allow for a glacial retreat history of the LGM ice sheets in the Ross Embayment to be determined. In particular, cores collected at Site 2, $15 \mathrm{~km}$ from the presentday calving line, display an exceptional well-preserved glacial retreat sequence of subglacial/grounding line proximal diamicts into grounding line proximal laminated muds, including a short-lived period of open water deposition of laminated muds with IRD, diatoms and foraminifera.

Provenance data collected from diamict at the base of the facies succession indicates that during the LGM, the ice flowing over the site was derived from the Byrd Glacier, whereas the provenance of clasts contained in the laminated muds with clasts and diatom oozes higher in the section do not contain lithologies consistent with transport from the Byrd Glacier, suggesting they were transported to the site from iceberg derived either from Ross Island or from Transantarctic Mountain outlet glacier to the north of the drill site.

- Radiocarbon dating of foraminifera in the laminated muds enable the timing of the first post-LGM open marine conditions at Coulman High to be dated at $7,600{ }^{14} \mathrm{C}$ yr BP (corrected age). This age constrain provides an age for the establishment of modern-day calving line following retreat of the LGM ice sheets and shelf in the Ross Embayment. This date also suggests that Ross Island has acted as a pinning point for the Ross Ice Shelf since the early Holocene. 
The ice shelf retreat in the Drygalski Trough has been calculated to be $\sim 100$ $\mathrm{m} \mathrm{a}^{-1}$, which correlates well with the retreat rate calculated in the Central Basin, with a retreat rate of $\sim 118 \mathrm{~m} \mathrm{a}^{-1}$. Due to the presence of the mm-scale laminae in the mudstone facies, and the corregated moraines in the JOIDES and Central Basin which are formed by the retreat of the grounding line, and it is suggested that the grounding line retreated at a maximum rate of $100 \mathrm{~m}$ $\mathrm{a}^{-1}$, it is likely that the grounding and calving line were coupled, and to close proximity to each other.

Open water conditions are likely to have occurred periodically through out much of the late Holocene, as all cores site contain an uppermost unit consisting of 10-30 cm of intensely bioturbated diatom ooze with abundant gravel and boulders, although due to the condensed and reworded nature of radiocarbon datable material in this unit, it is difficult to accurately date the interval of which these have been deposited.

Future work entails high resolution sampling of an additional core from Site 2 for foraminifera to establish a better chronology of the retreat of the ice shelf and possible ice sheet in the Ross Sea. This will also enable the analyses of $\delta^{18} \mathrm{O}$ of additional foraminifera found, which will give an insight if there has been an enhanced basal melting prior to the collapse of the ice shelf at this location (Domack et al., 2005). 


\section{References}

Ackert Jr., R. (2008). Swinging gate or Saloon doors: Do we need a new model of Ross Sea deglaciation? In WAIS Divide Science Meeting.

Alley, R., Anandakrishnan, S., Dupont, T., Parizek, B., and Pollard, D. (2007). Effect of sedimentation on ice-sheet grounding-line stability. Science, 315(5820):1838-1841.

Alley, R., Blankenship, D., Bentley, C., and Rooney, S. (1986). Deformation of till beneath ice stream B, West Antarctica.

Alley, R., Blankenship, D., Rooney, S., and Bentley, C. (1989). Sedimentation beneath ice shelves-the view from Ice Stream B. Marine Geology, 85(2-4):101120.

Anandakrishnan, S. and Alley, R. (1997). Tidal forcing of basal seismicity of ice stream C, West Antarctica, observed far inland. Journal of Geophysical ResearchAll Series, 102:15-15.

Anandakrishnan, S., Catania, G., Alley, R., and Horgan, H. (2007). Discovery of till deposition at the grounding line of Whillans Ice Stream. Science, 315(5820):18351838 .

Anderson, J. (1999). Antarctic marine geology, volume 289. Cambridge Univ Press.

Anderson, J., Kurtz, D., Domack, E., and Balshaw, K. (1980). Glacial and glacial marine sediments of the Antarctic continental shelf. The Journal of Geology, pages 399-414.

Andrews, J., Domack, E., Cunningham, W., Leventer, A., Licht, K., Jull, A., DeMaster, D., and Jennings, A. (1999). Problems and possible solutions concerning radiocarbon dating of surface marine sediments, Ross Sea, Antarctica. Quaternary Research, 52(2):206-216. 
Arblaster, J. and Meehl, G. (2006). Contributions of external forcings to Southern Annular Mode trends. Journal of Climate, 19(12):2896-2905.

Barrett, P. (1996). Antarctic palaeoenvironment through Cenozoic times- a review. Terra Antartica, 3(2):103-119.

Barrett, P. (2008). A History of Antarctic Cenozoic Glaciation-View from the Margin. Developments in Earth and Environmental Sciences, 8:33-83.

Barrett, P., Carter, L., Damiani, D., Dunbar, G., Dunker, E., Giorgetti, G., Harper, M., McKay, R., Niessen, F., Nixdorf, U., Pyne, A., Riesselmann, C., Robinson, N., Hollis, C., and Strong, P. (2005). Oceanography and sedimentation beneath the McMurdo Ice Shelf in Windless Bight, Antarctica. Antarctic Data Series, 25.

Barrows, T., Juggins, S., De Deckker, P., Calvo, E., Pelejero, C., et al. (2007). Longterm sea surface temperature and climate change in the Australian-New Zealand region. Paleoceanography, 22(2):PA2215.

Behrendt, J., LeMasurier, W., Cooper, A., Tessensohn, F., Trehu, A., and Damaske, D. (1991). Geophysical studies of the West Antarctic rift system. Tectonics, 10(6):1257-1273.

Bennett, M., Doyle, P., Mather, A., and Woodfin, J. (1994). Testing the climatic significance of dropstones: An example from southeast Spain. Geological MagazineLondon, 131:845-845.

Bentley, M., Hodgson, D., Sugden, D., Roberts, S., Smith, J., Leng, M., and Bryant, C. (2005). Early Holocene retreat of the George VI Ice Shelf, Antarctic Peninsula. Geology, 33(3):173.

Bertler, N., Barrett, P., Mayewski, P., Fogt, R., Kreutz, K., and Shulmeister, J. (2004). El Nino Suppresses Antarctic Warming. Geophysical Research Letters, $31(15)$.

Blunier, T., Chappellaz, J., Schwander, J., Dällenbach, A., Stauffer, B., Stocker, T., Raynaud, D., Jouzel, J., Clausen, H., Hammer, C., et al. (1998). Asynchrony of Antarctic and Greenland climate change during the last glacial period. Nature, 394(6695):739-743.

Borg, S., DePaolo, D., Wendlandt, E., and Drake, T. (1989). Studies of granites and metamorphic rocks, Byrd Glacier area. Antarctic Journal of the United States, 24(5):19-21. 
Ciais, P., Petit, J., Jouzel, J., Lorius, C., Barkov, N., Lipenkov, V., and Nicolaïev, V. (1992). Evidence for an early holocene climatic optimum in the antarctic deep ice-core record. Climate Dynamics, 6(3):169-177.

Conway, H., Hall, B., Denton, G., Gades, A., and Waddington, E. (1999). Past and future grounding-line retreat of the West Antarctic ice sheet. Science, 286(5438):280-283.

Cooper, A., Brancolini, G., Escutia, C., Kristoffersen, Y., Larter, R., Leitchenkov, G., O'Brien, P., and Jokat, W. (2008). Cenozoic climate history from seismic reflection and drilling studies on the Antarctic continental margin. Developments in Earth and Environmental Sciences, 8:115-234.

Cooper, A., Davey, F., and Behrendt, J. (1987). Seismic stratigraphy and structure of the Victoria Land basin, western Ross Sea, Antarctica. The Antarctic continental margin: geology and geophysics of the western Ross Sea, 5:27-76.

Craddock, C. (1972). Geologic Map of Antarctica, 1: 5,000,000. American Geographical Society.

Cullather, R., Bromwich, D., and Van Woert, M. (1996). Interannual variations in Antarctic precipitation related to El Nino-Southern oscillation. Journal of Geophysical Research, 101(D14):19109-19.

Cunningham, W. and Leventer, A. (1998). Diatom assemblages in surface sediments of the Ross Sea: relationship to present oceanographic conditions. Antarctic Science-Institutional Subscription, 10(2):134-146.

Dalziel, I. and Elliot, D. (1982). West Antarctica: problem child of Gondwanaland. Tectonics, 1(1):3-19.

Denton, G. and Hughes, T. (2000). Reconstruction of the Ross ice drainage system, Antarctica, at the last glacial maximum. Geografiska Annaler: Series A, Physical Geography, 82(2-3):143-166.

Deschamps, P., Durand, N., Bard, E., Hamelin, B., Camoin, G., Thomas, A., Henderson, G., Okuno, J., and Yokoyama, Y. (2012). Ice-sheet collapse and sea-level rise at the Bolling warming 14,600 [thinsp] years ago. Nature, 483(7391):559-564.

Domack, E. (1990). Laminated terrigenous sediments from the Antarctic Peninsula: the role of subglacial and marine processes. Geological Society, London, Special Publications, 53(1):91-103. 
Domack, E., Duran, D., Leventer, A., Ishman, S., Doane, S., McCallum, S., Amblas, D., Ring, J., Gilbert, R., and Prentice, M. (2005). Stability of the Larsen $\mathrm{B}$ ice shelf on the Antarctic Peninsula during the Holocene epoch. Nature, 436(7051):681-685.

Domack, E., Jacobson, E., Shipp, S., and Anderson, J. (1999). Late PleistoceneHolocene retreat of the West Antarctic Ice-sheet system in the Ross Sea: Part 2-Sedimentologic and stratigraphic signature. Geological Society of America Bulletin, 111(10):1517.

Domack, E., Jull, A., , J., Linick, T., and Williams, C. (1989). Application of tandem accelerator mass-spectrometer dating to late Pleistocene-Holocene sediments of the East Antarctic continental shelf. Quaternary Research, 31(2):277-287.

Dowdeswell, J., Whittington, R., and Marienfeld, P. (1994). The origin of massive diamicton facies by iceberg rafting and scouring, Scoresby Sund, East Greenland. Sedimentology, 41(1):21-35.

Dunbar, G., Bertler, N., and McKay, R. (2009). Sediment flux through the McMurdo Ice Shelf in Windless Bight, Antarctica. Global and Planetary Change, 69(3):8793.

Dunbar, G., Naish, T., Barrett, P., Fielding, C., and Powell, R. (2008). Constraining the amplitude of late Oligocene bathymetric changes in Western Ross Sea during orbitally-induced oscillations in the East Antarctic Ice Sheet:(1) Implications for glacimarine sequence stratigraphic models. Palaeogeography, Palaeoclimatology, Palaeoecology, 260(1):50-65.

Esser, R., Kyle, P., and McIntosh, W. (2004). 40 Ar/39 Ar dating of the eruptive history of Mount Erebus, Antarctica: volcano evolution. Bulletin of volcanology, 66(8):671-686.

Fahnestock, M., Scambos, T., Bindschadler, R., and Kvaran, G. (2000). A millennium of variable ice flow recorded by the Ross Ice Shelf, Antarctica. Journal of Glaciology, 46(155):652-664.

Fairbanks, R. (1989). A 17, 000-year glacio-eustatic sea level record: influence of glacial melting rates on the Younger Dryas event and deep-ocean circulation. Nature, 342(6250):637-642. 
Ferrigno, J., Foley, K., Swithinbank, C., and Williams, R.S., J. (2008). Coastalchange and Glaciological Map of the Northern Ross Ice Shelf, Antarctica, 19402005. U.S. Geological Survey Geologic Investigations Series Map I2600H, 1 map sheet, 11-p. text.

Fielding, C., Naish, T., Woolfe, K., and Lavelle, M. (2000). Facies analysis and sequence stratigraphy of CRP-2/2A, Victoria Land Basin, Antarctica.

Fielding, C., Whittaker, J., Henrys, S., Wilson, T., and Naish, T. (2008). Seismic facies and stratigraphy of the Cenozoic succession in McMurdo Sound, Antarctica: Implications for tectonic, climatic and glacial history. Palaeogeography, Palaeoclimatology, Palaeoecology, 260(1-2):8-29.

Fischbein, S. (2010). GPS station Coulman High, Site 1. Technical report, University of Nebraska-Lincoln.

Fyfe, J., Boer, G., and Flato, G. (1999). Arctic and Antarctic oscillations and their projected changes under global warming. Geophysical Research Letters, 26(11):1601-1604.

Gordon, J. and Harkness, D. (1992). Magnitude and geographic variation of the radiocarbon content in Antarctic marine life: implications for reservoir corrections in radiocarbon dating. Quaternary Science Reviews, 11(7):697-708.

Hall, B. and Denton, G. (1999). New relative sea-level curves for the southern Scott Coast, Antarctica: evidence for Holocene deglaciation of the western Ross Sea. Journal of Quaternary Science, 14(7):641-650.

Hall, B. and Denton, G. (2000). Radiocarbon chronology of Ross Sea drift, eastern Taylor Valley, Antarctica: Evidence for a grounded ice sheet in the Ross Sea at the last glacial maximum. Geografiska Annaler: Series A, Physical Geography, $82(2-3): 305-336$.

Hall, J., Wilson, T., and Henrys, S. (2007). Structure of the central Terror Rift, Western Ross Sea, Antarctica. Antarctica: A Keystone in a Changing WorldOnline Proceedings of the 10th ISAES, edited by AK Cooper and Raymond CR et al., USGS Open-File Report, 1047.

Hambrey, M., Ehrmann, W., and Larsen, B. (1991). Cenozoic glacial record of the Prydz Bay continental shelf, East Antarctica. In: Barron, J; Larsen, B, et al.(eds.), Proc. ODP, Sci. Results, College Station, TX.(Ocean Drilling Program), 119, 77-132, 119:77-132. 
Hambrey, M. and McKelvey, B. (2000). Major Neogene fluctuations of the East Antarctic ice sheet: Stratigraphic evidence from the Lambert Glacier region. Geology, 28(10):887-890.

Haran, T., Bohlander, J., Scambos, T., and Fahnestock, M. (2005). MODIS mosaic of Antarctica (MOA) image map. National Snow and Ice Data Center, Boulder, CO, USA.

Hemer, M. and Harris, P. (2003). Sediment core from beneath the Amery Ice Shelf, East Antarctica, suggests mid-Holocene ice-shelf retreat. Geology, 31(2):127.

Henrys, S., Wilson, T., Whittaker, J., Fielding, C., Hall, J., and Naish, T. (2007). Tectonic history of mid-Miocene to present southern Victoria Land Basin, inferred from seismic stratigraphy in McMurdo Sound, Antarctica. Antarctica: A Keystone in a Changing World-Online Proceedings of the 10th ISAES, edited by AK Cooper and Raymond CR et al., USGS Open-File Report, 1047.

Holland, P., Jenkins, A., and Holland, D. (2008). The response of ice shelf basal melting to variations in ocean temperature. Journal of Climate, 21(11):2558-2572.

Horgan, H., Walker, R., Anandakrishnan, S., and Alley, R. (2011). Surface elevation changes at the front of the Ross Ice Shelf: Implications for basal melting. Journal of Geophysical Research, 116(C2):C02005.

Hughes, T. (1977). West Antarctic ice streams. Reviews of Geophysics and Space Physics, 15(1).

Indermühle, A., Stocker, T., Joos, F., Fischer, H., Smith, J., Wahlen, M., Deck, B., Mastroianni, D., Tschumi, J., Blunier, T., et al. (1999). Holocene carboncycle dynamics based on CO2 trapped in ice at Taylor Dome, Antarctica. Nature, 398:121-126.

IOC and IHO (2003). Centenary Edition of the GEBCO Digital Atlas, published on CD-ROM on behalf of the Intergovernmental Oceanographic Commission and the International Hydrographic Organization as part of the General Bathymetric Chart of the Oceans. British oceanographic data centre, Liverpool.

Jacka, T. and Budd, W. (1998). Detection of temperature and sea-ice-extent changes in the Antarctic and Southern Ocean, 1949-96. Annals of Glaciology, 27(1):553559 .

Jacobs, S. (2004). Bottom water production and its links with the thermohaline circulation. Antarctic Science, 16(4):427-437. 
Jacobs, S., Hellmer, H., and Jenkins, A. (1996). Antarctic ice sheet melting in the Southeast Pacific. Geophysical Research Letters, 23(9):957-960.

Jacobs, S., Jenkins, A., Giulivi, C., and Dutrieux, P. (2011). Stronger ocean circulation and increased melting under Pine Island Glacier ice shelf. Nature Geoscience, $4(8): 519-523$.

Jouzel, J., Masson-Delmotte, V., Cattani, O., Dreyfus, G., Falourd, S., Hoffmann, G., Minster, B., Nouet, J., Barnola, J., Chappellaz, J., et al. (2007). Orbital and millennial Antarctic climate variability over the past 800,000 years. Science, 317(5839):793-796.

Kellogg, T., Hughes, T., and Kellogg, D. (1996). Late Pleistocene interactions of East and West Antarctic ice-flow regimes: evidence from the McMurdo Ice Shelf. Journal of Glaciology, 42(142):486.

Konfirst, M., Scherer, R., Hillenbrand, C., and Kuhn, G. (2012). A marine diatom record from the Amundsen Sea-Insights into oceanographic and climatic response to the Mid-Pleistocene Transition in the West Antarctic sector of the Southern Ocean. Marine Micropaleontology, 92-93:40-51.

Kurtz, D. and Anderson, J. (1979). Recognition and sedimentologic description of recent debris flow deposits from the Ross and Weddell Seas, Antarctica. Journal of Sedimentary Research, 49(4):1159-1169.

Kyle, P. and Cole, J. (1974). Structural control of volcanism in the McMurdo Volcanic Group, Antarctica. Bulletin of Volcanology, 38(1):16-25.

Lazzara, M., Jezek, K., Scambos, T., MacAyeal, D., and Van Der Veen, C. (2008). On the recent calving of icebergs from the Ross Ice Shelf. Polar Geography, 31(1$2): 15-26$.

Lewis, D. and McConchie, D. (1994). Analytical sedimentology. New York, NY (United States); Chapman Hall.

Licht, K. and Andrews, J. (2002). The $14 \mathrm{C}$ record of Late Pleistocene ice advance and retreat in the central Ross Sea, Antarctica. Arctic, Antarctic, and Alpine Research, pages 324-333.

Licht, K., Dunbar, N., Andrews, J., and Jennings, A. (1999). Distinguishing subglacial till and glacial marine diamictons in the western Ross Sea, Antarctica: Implications for a last glacial maximum grounding line. Geological Society of America Bulletin, 111(1):91-103. 
Licht, K. and Fastook, J. (1998). Constraining a numerical ice sheet model with geologic data over one ice sheet advance/retreat cycle in the Ross Sea. In Chapman Conference on the West Antarctic Ice Sheet, University of Maine, pages 25-26.

Licht, K., Jennings, A., Andrews, J., and Williams, K. (1996). Chronology of late Wisconsin ice retreat from the western Ross Sea, Antarctica. Geology, 24(3):223226 .

Licht, K., Lederer, J., and Jeffrey Swope, R. (2005). Provenance of LGM glacial till (sand fraction) across the Ross embayment, Antarctica. Quaternary Science Reviews, 24(12-13):1499-1520.

MacAyeal, D. (1984). Numerical simulations of the Ross Sea tides. Journal of Geophysical Research, 89(C1):607-715.

Mackintosh, A., Golledge, N., Domack, E., Dunbar, R., Leventer, A., White, D., Pollard, D., DeConto, R., Fink, D., Zwartz, D., et al. (2011). Retreat of the East Antarctic ice sheet during the last glacial termination. Nature Geoscience, $4(3): 195-202$.

Masson, V., Vimeux, F., Jouzel, J., Morgan, V., Delmotte, M., Ciais, P., Hammer, C., Johnsen, S., Lipenkov, V., Mosley-Thompson, E., et al. (2000). Holocene climate variability in Antarctica based on 11 ice-core isotopic records. Quaternary Research, 54(3):348-358.

Mazullo, J., Graham, A., and Program, O. D. (1988). Handbook for shipboard sedimentologists. Ocean Drilling Program, Texas A\&M University.

McCave, I., Manighetti, B., and Robinson, S. (1995). Sortable silt and fine sediment size/composition slicing: Parameters for palaeocurrent speed and palaeoceanography. Paleoceanography, 10(3):593-610.

McKay, R. (2008). Late Cenozoic (13-0 Myr) Glacimarine Sedimentology, Facies Analysis, and Sequence Stratigraphy from the Western Ross Embayment, Antarctica: Implications for the Variability of the Antarctic Ice Sheets. PhD thesis, Victoria University of Wellington.

McKay, R., Browne, G., Carter, L., Cowan, E., Dunbar, G., Krissek, L., Naish, T., Powell, R., Reed, J., Talarico, F., et al. (2009). The stratigraphic signature of the late Cenozoic Antarctic Ice Sheets in the Ross Embayment. Bulletin of the Geological Society of America, 121(11-12):1537. 
McKay, R., Dunbar, G., Naish, T., Barrett, P., Carter, L., and Harper, M. (2008). Retreat history of the Ross Ice Sheet (Shelf) since the Last Glacial Maximum from deep-basin sediment cores around Ross Island. Palaeogeography, Palaeoclimatology, Palaeoecology, 260(1-2):245-261.

McKay, R., Naish, T., Carter, L., Riesselman, C., Dunbar, R., Sjunneskog, C., Winter, D., Sangiorgi, F., Warren, C., Pagani, M., et al. (2012a). Antarctic and Southern Ocean influences on Late Pliocene global cooling. Proceedings of the National Academy of Sciences, 109(17):6423-6428.

McKay, R., Naish, T., Powell, R., Barrett, P., Scherer, R., Talarico, F., Kyle, P., Monien, D., Kuhn, G., Jackolski, C., et al. (2012b). Pleistocene variability of Antarctic Ice Sheet extent in the Ross Embayment. Quaternary Science Reviews, 34:93-112.

Mercer, J. (1978). West Antarctic ice sheet and CO2 greenhouse effect: a threat of disaster. Nature, 271(5643):321-325.

Milankovitch, M. (1941). Canon of insolation and the ice-age problem. Royal Serbian Academy Special Publication.

Moncrieff, A. (1989). Classification of poorly-sorted sedimentary rocks. Sedimentary Geology, 65(1-2):191-194.

Moore, J. and Kyle, P. (1990). Volcanics of the Antarctica Plate and Southern Oceans, chapter A.17. Mount Erebus, pages 103-108. American Geophysical Union, Washington, DC.

Mosola, A. and Anderson, J. (2006). Expansion and rapid retreat of the West Antarctic Ice Sheet in eastern Ross Sea: possible consequence of over-extended ice streams? Quaternary Science Reviews, 25(17-18):2177-2196.

Mulvaney, R., Röthlisberger, R., Wolff, E., Sommer, S., Schwander, J., Hutterli, M., and Jouzel, J. (2000). The transition from the Last Glacial Period in inland and near-coastal Antarctica. Geophysical Research Letters, 27(17):2673-2676.

Naish, T., Levy, R., Powell, R., and the ANDRILL-MIS Science-Operations Team (2006). Scientific Logistics Implementation Plan for the ANDRILL McMurdo Ice Shelf Project. pages 1-138.

Naish, T., Powell, R., Levy, R., and the ANDRILL-MIS Science Team (2007). Initial science results from AND-B, ANDRILL McMurdo Ice Shelf Project, Antarctica. Terra Antartica, 14(2). 
Naish, T., Powell, R., Levy, R., Wilson, G., Scherer, R., Talarico, F., Krissek, L., Niessen, F., Pompilio, M., Wilson, T., et al. (2009). Obliquity-paced Pliocene West Antarctic ice sheet oscillations. Nature, 458(7236):322-328.

Naish, T., Woolfe, K., Barrett, P., Wilson, G., Atkins, C., Bohaty, S., Bücker, C., Claps, M., Davey, F., Dunbar, G., et al. (2001). Orbitally induced oscillations in the east antarctic ice sheet at the oligocene/miocene boundary. Nature, pages 719-723.

Ó Cofaigh, C., Dowdeswell, J., Allen, C., Hiemstra, J., Pudsey, C., Evans, J., and JA Evans, D. (2005). Flow dynamics and till genesis associated with a marinebased Antarctic palaeo-ice stream. Quaternary Science Reviews, 24(5-6):709-740.

Ó Cofaigh, C., Dowdeswell, J., and Grobe, H. (2001). Holocene glacimarine sedimentation, inner Scoresby Sund, East Greenland: the influence of fast-flowing ice-sheet outlet glaciers. Marine Geology, 175(1):103-129.

Orsi, A., Johnson, G., and Bullister, J. (1999). Circulation, mixing, and production of Antarctic Bottom Water. Progress in Oceanography, 43(1):55-109.

Paterson, W. (1994). The physics of glaciers. Butterworth-Heinemann, 3rd edition.

Pollard, D. and DeConto, R. (2009). Modelling West Antarctic ice sheet growth and collapse through the past five million years. Nature, 458(7236):329-332.

Pritchard, H., Ligtenberg, S., Fricker, H., Vaughan, D., van den Broeke, M., and Padman, L. (2012). Antarctic ice-sheet loss driven by basal melting of ice shelves. Nature, 484(7395):502-505.

Pudsey, C. and Evans, J. (2001). First survey of Antarctic sub-ice shelf sediments reveals mid-Holocene ice shelf retreat. Geology, 29(9):787-790.

Reimer, P., Baillie, M., Bard, E., Bayliss, A., Beck, J., Blackwell, P., Ramsey, C., Buck, C., Burr, G., Edwards, R., et al. (2009). IntCal09 and Marine09 radiocarbon age calibration curves, 0-50,000 years cal BP. Radiocarbon 51:1111-1150.

Rignot, E., Casassa, G., Gogineni, P., Krabill, W., Rivera, A., and Thomas, R. (2004). Accelerated ice discharge from the Antarctic Peninsula following the collapse of Larsen B ice shelf. Geophys. Res. Lett, 31(18):L18401.

Rignot, E. and Jacobs, S. (2002). Rapid bottom melting widespread near Antarctic ice sheet grounding lines. Science, 296(5575):2020-2023. 
Rignot, E., Mouginot, J., and Scheuchl, B. (2011). Ice flow of the Antarctic ice sheet. Science, 333(6048):1427-1430.

Rott, H., Rack, W., Nagler, T., and Skvarca, P. (1998). Climatically induced retreat and collapse of northern Larsen Ice Shelf, Antarctic Peninsula. Annals of Glaciology, 27:86-92.

Scambos, T., Bohlander, J., Shuman, C., Skvarca, P., et al. (2004). Glacier acceleration and thinning after ice shelf collapse in the Larsen B embayment, Antarctica. Geophysical Research Letters, 31:L18402.

Scherer, R., Sjunneskog, C., Iverson, N., and Hooyer, T. (2004). Assessing subglacial processes from diatom fragmentation patterns. Geology, 32(7):557.

Schoof, C. (2007). Ice sheet grounding line dynamics: Steady states, stability, and hysteresis. J. Geophys. Res, 112(10.1029).

Shabtaie, S. and Bentley, C. (1987). West Antarctic ice streams draining into the Ross Ice Shelf: configuration and mass balance. Journal of Geophysical Research, 92(B2):1311-1336.

Shakun, J., Clark, P., He, F., Marcott, S., Mix, A., Liu, Z., Otto-Bliesner, B., Schmittner, A., and Bard, E. (2012). Global warming preceded by increasing carbon dioxide concentrations during the last deglaciation. Nature, 484(7392):4954 .

Shepherd, A., Wingham, D., Mansley, J., and Corr, H. (2001). Inland thinning of Pine Island Glacier, West Antarctica. Science, 291(5505):862-864.

Shepherd, A., Wingham, D., and Rignot, E. (2004). Warm ocean is eroding West Antarctic Ice Sheet. Geophys. Res. Lett, 31(23):L23404.

Shevenell, A., Ingalls, A., Domack, E., and Kelly, C. (2011). Holocene Southern Ocean surface temperature variability west of the Antarctic Peninsula. Nature, 470(7333):250-254.

Shipp, S., Anderson, J., and Domack, E. (1999). Late Pleistocene-Holocene retreat of the West Antarctic ice-sheet system in the Ross Sea: Part 1-Geophysical results. Geological Society of America Bulletin, 111(10):1486.

Shipp, S., Wellner, J., and Anderson, J. (2002). Retreat signature of a polar ice stream: sub-glacial geomorphic features and sediments from the Ross Sea, Antarctica. Special publication-Geological Society of London, 203:277-304. 
Smethie, W. et al. (2005). Circulation and melting under the Ross Ice Shelf: estimates from evolving CFC, salinity and temperature fields in the Ross Sea. Deep Sea Research Part I: Oceanographic Research Papers, 52(6):959-978.

Steig, E., Morse, D., Waddington, E., Stuiver, M., Grootes, P., Mayewski, P., Twickler, M., and Whitlow, S. (2000). Wisconsinan and Holocene climate history from an ice core at Taylor Dome, western Ross Embayment, Antarctica. Geografiska Annaler: Series A, Physical Geography, 82(2-3):213-235.

Steig, E., Schneider, D., Rutherford, S., Mann, M., Comiso, J., and Shindell, D. (2009). Warming of the Antarctic ice-sheet surface since the 1957 International Geophysical Year. Nature, 457(7228):459-462.

Stenni, B., Buiron, D., Frezzotti, M., Albani, S., Barbante, C., Bard, E., Barnola, J., Baroni, M., Baumgartner, M., Bonazza, M., et al. (2010). Expression of the bipolar see-saw in Antarctic climate records during the last deglaciation. Nature Geoscience, 4(1):46-49.

Stuiver, M., Denton, G., Hughes, T., and Fastook, J. (1981). History of the marine ice sheet in West Antarctica during the last glaciation: a working hypothesis, pages 319-436. Wiley-Interscience, New York.

Suttner, L. (1974). Sedimentary petrographic provinces: an evaluation. Paleogeographic Provinces and Provinciality, 21:75-84.

Suttner, L., Basu, A., and Mack, G. (1981). Climate and the origin of quartz arenites. Journal of Sedimentary Research, 51(4):1235.

Thomas, R. (1979). The dynamics of marine ice sheets. J. Glaciol, 24(90):167-177.

Thomas, R. and Bentley, C. (1978). A model for Holocene retreat of the West Antarctic ice sheet. Quaternary Research, 10(2):150-170.

Thompson, D. and Solomon, S. (2002). Interpretation of recent Southern Hemisphere climate change. Science, 296(5569):895-899.

Tulaczyk, S., Kamb, B., Scherer, R., and Engelhardt, H. (1998). Sedimentary processes at the base of a West Antarctic ice stream; constraints from textural and compositional properties of subglacial debris. Journal of Sedimentary Research, 68(3):487-496. 
Uri, S., Hackney, R., Bannister, S., Stern, T., and Makovsky, Y. (1997). Uplift of the Transantarctic Mountains and the bedrock beneath the East Antarctic ice sheet. Journal of Geophysical Research, 102(B12):27603.

van der Meer, J. (1993). Microscopic evidence of subglacial deformation. Quaternary Science Reviews, 12(7):553-587.

Vaughan, D. and Doake, C. (1996). Recent atmospheric warming and retreat of ice shelves on the Antarctic Peninsula. Nature, 379(6563):328-331.

Watson, T., Nyblade, A., Wiens, D., Anandakrishnan, S., Benoit, M., Shore, P., Voigt, D., and VanDecar, J. (2006). P and S velocity structure of the upper mantle beneath the Transantarctic Mountains, East Antarctic craton, and Ross Sea from travel time tomography. Geochemistry Geophysics Geosystems, 7(7):Q07005.

Wright, A. and Kyle, P. (1990a). Volcanics of the Antarctica Plate and Southern Oceans, chapter A.15. Mount Bird, pages 97-98. American Geophysical Union, Washington, DC.

Wright, A. and Kyle, P. (1990b). Volcanics of the Antarctica Plate and Southern Oceans, chapter A.16. Mount Terror, pages 99-102. American Geophysical Union, Washington, DC.

Wuchter, C., Schouten, S., Coolen, M., and Damsté, J. (2004). Temperaturedependent variation in the distribution of tetraether membrane lipids of marine Crenarchaeota: Implications for TEX86 paleothermometry. Paleoceanography, 19(4):PA4028. 


\section{Appendix A}

\section{Field Methods}

The site survey included the following operations (Table A.1):

i) Camp setup: This involved a traverse from McMurdo Station to the Coulman High site. The move from one site to another was achieved with two Caterpillar D6 tractors as prime movers dragging seven containers at a time. The camp encompassed 15 containers, of which six were used as living quarters, with the remainder were used as storage, work sheds and drilling space. During the field season, camp was moved three times and the move took less than a day.

ii) Hot water drill (HWD) operation: The HWD had been deployed successfully in the past through an ice thickness of $80 \mathrm{~m}$. This field season was to test the HWD through thicker ice at Coulman High, where the ice is up to $273 \mathrm{~m}$ thick. Drilling a hole through the ice, making a bulb to act as a water reservoir and reaming the hole to a uniform diameter took two days.

iii) Oceanograhic measurements: Two oceanographic moorings were deployed, each comprised five Nortek Aquadopps and five SeaBird Microcat inductive modem instruments and were placed at five depths in the water column. The Aquadopps measured the current strength and direction, whilst the Microcats measured salinity, temperature and pressure. The National Institute of Water and Atmosphere (NIWA) mooring was deployed at Site 1, on November 24, initially planned for two months. The Woods Hole Oceanographic Institute (WHOI) mooring was deployed at Site 2, on December 1, and it was recovered on January 23. The NIWA mooring was recovered on January 17 and redeployed on January 21 to stay in place for three years. At all sites, CTD measurements were carried out. At Site 2 and 3, a 28-hour long CTD (Conductivity/Temperature/Depth) profile was done. In addition at Site 3, water samples were taken. 
iv Sediment cores: At all four sites sediment cores were recovered using a gravity corer with a plastic core barrel ranging in length from $0.5 \mathrm{~m}$ to $2 \mathrm{~m}$, which was provided by the Alfred Wegener Institute. The corer was deployed using different barrel lengths. A total of 28 cores were recovered with the longest measuring $1.3 \mathrm{~m}$.

v) Video imagery: The Downhole Optical Calibration Tool for Observing Roundness (DOCTOR) was used to image the hole through the ice shelf and image the sea floor. The DOCTOR was used at all sites, sometimes in combination with the CTD to get accurate depths and temperatures of the water in the hole as an indication of how quickly the hole would refreeze. At Site 3 and 4 the Submersible Capable of under Ice Navigation and Imaging (SCINI) robot was used to image the bottom of the ice shelf.

vi) Gravity survey: The gravity survey took place between December 7 and December 14, 2010. This survey was conducted by Otago University, led by Gary Wilson.

vii) VSP: Vertical Seismic Profile with the receiver suspended in the water column at Site 4. The VSP survey was carried out by University of California, Santa Barbara, led by Doug Wilson and Bruce Luyendyk. 


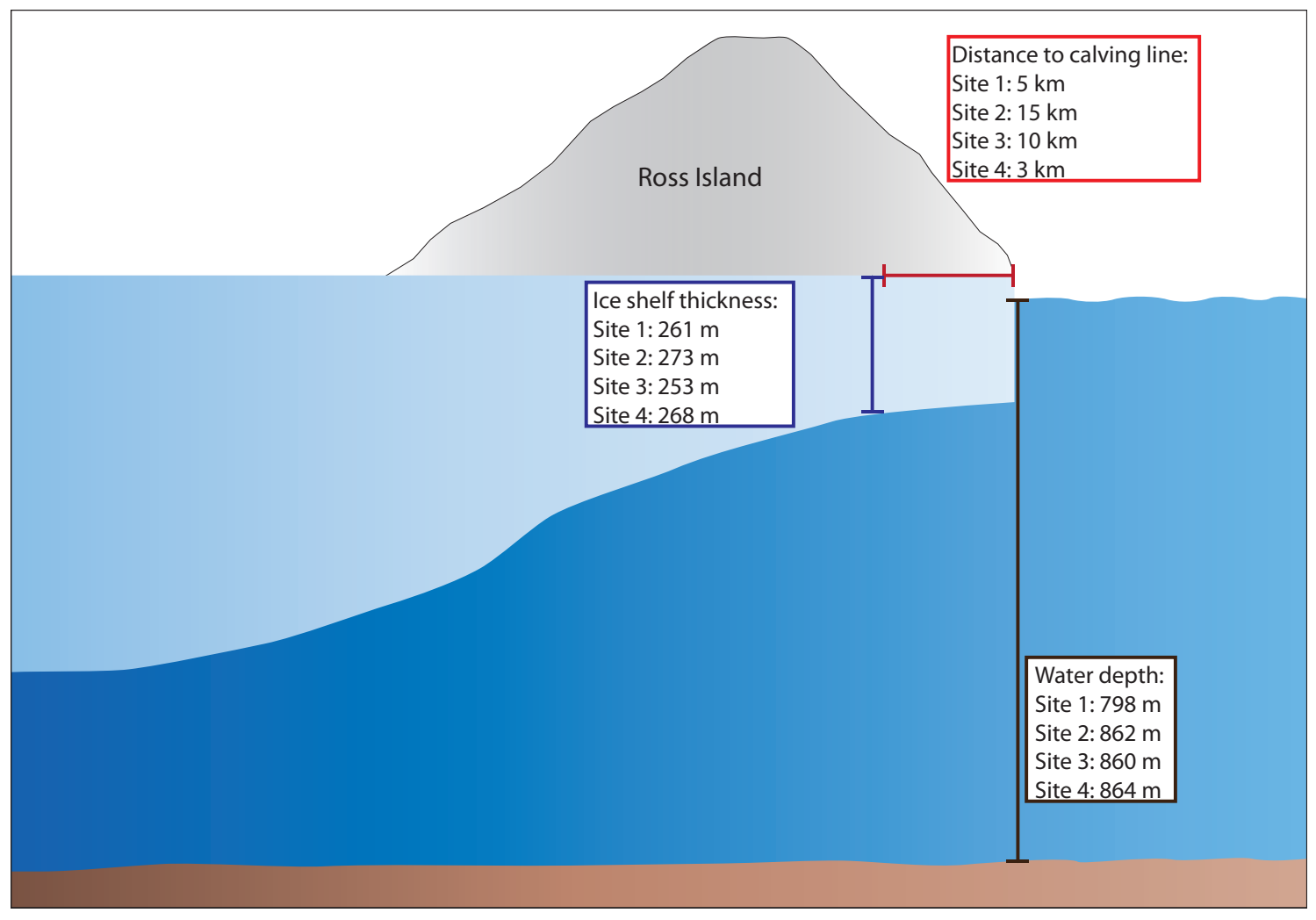

Figure A.1: Sketch to illustrate the thickness of the ice shelf, distance from calving line, and the water column depth. 


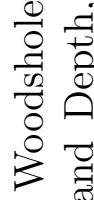




\section{Appendix B}

\section{Data from all cores}

This appendix contains

- Stratigraphic logs form all cores that were split

- Plot of the physical properties from the multi sensor core logging tool (Figure B.8; B.9; B.10; B.11)

- Physical property data on CHGC-14 including physical properties from AWI (Figure B.2; Table B.1; B.3)

- Diatom content in CHGC-08 (Table B.4)

- Grain size data log on CHGC-08 (Figure B.13; B.14)

- Grain size data on CHGC-08 (Table B.5)

- Petrology counts for CHGC-08 (Table B.9)

- Sortable silt data on CHGC-08 (Figure B.15) 


\section{Stratigraphic logs}

- CHGC-05, Site 1 (Figure B.1)

- CHGC-07, Site 2 (Figure B.2)

- CHGC-11, Site 2 (Figure B.3)

- CHGC-14, Site 3 (Figure B.4)

- CHGC-17, Site 3 (Figure B.5)

- CHGC-22, Site 4 (Figure B.6)

- CHGC-23, Site 4 (Figure B.7)

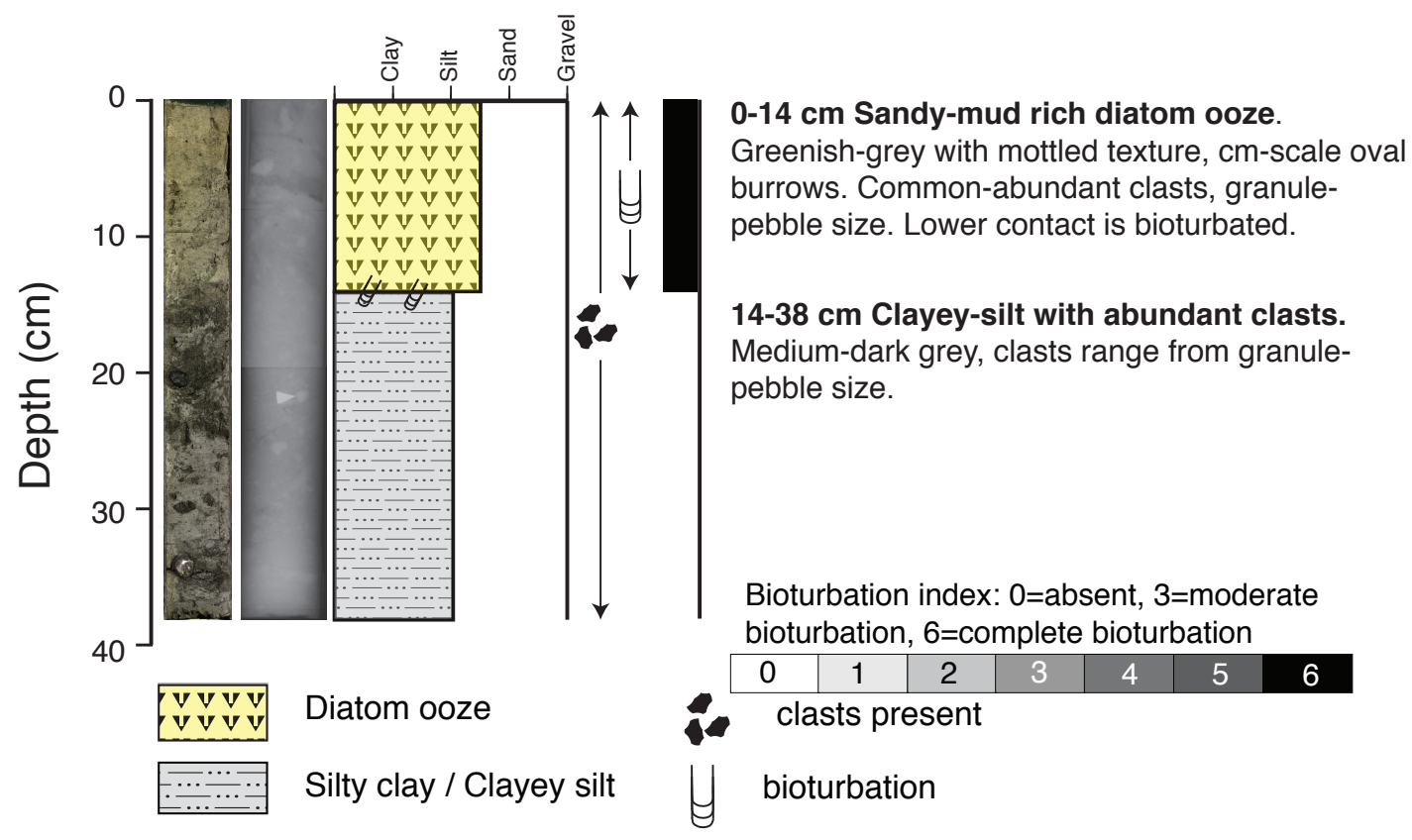

Figure B.1: Stratigraphic log for CHGC-05 


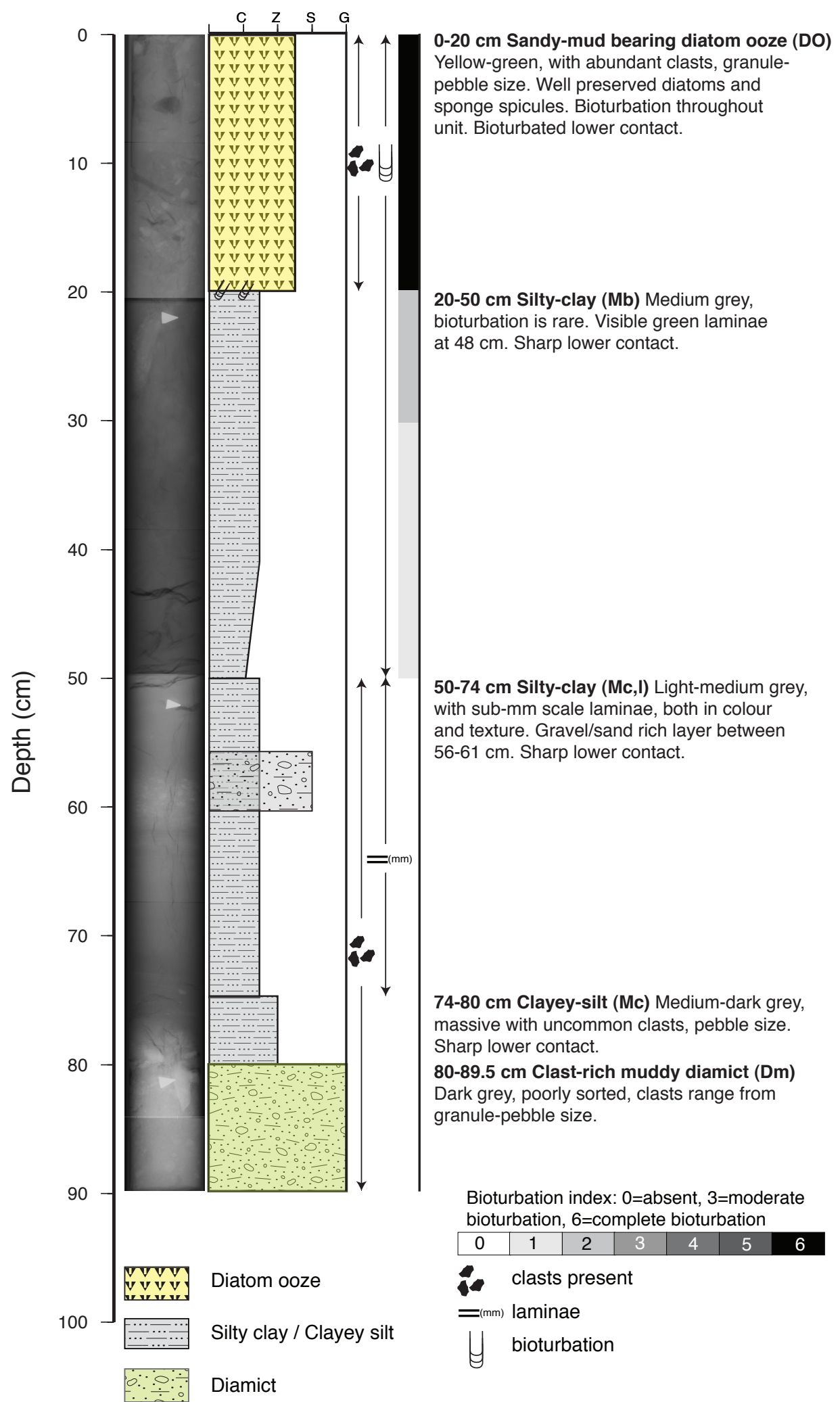

Figure B.2: Stratigraphic log for CHGC-07 


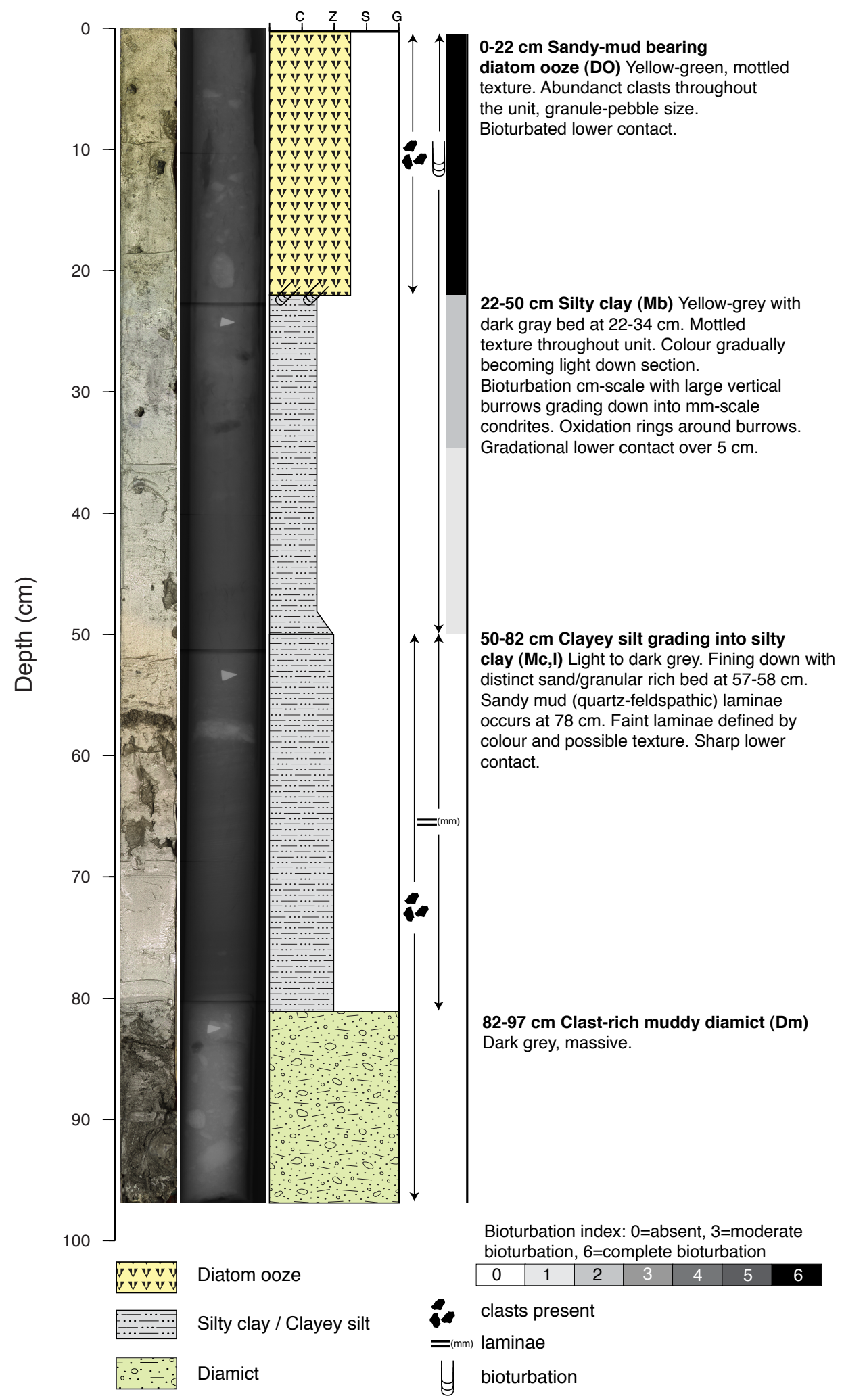

Figure B.3: Stratigraphic log for CHGC-11 


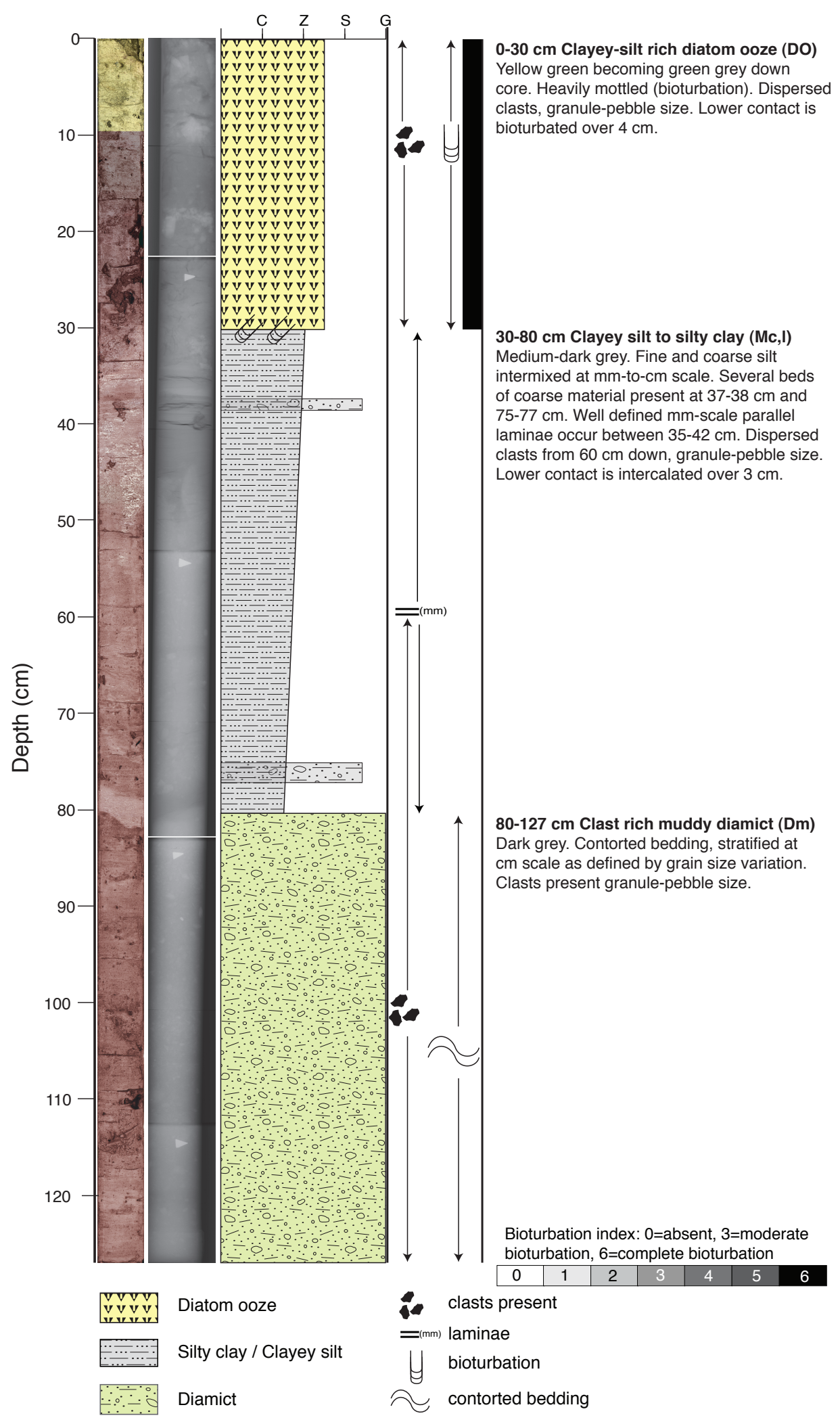

Figure B.4: Stratigraphic log for CHGC-14 


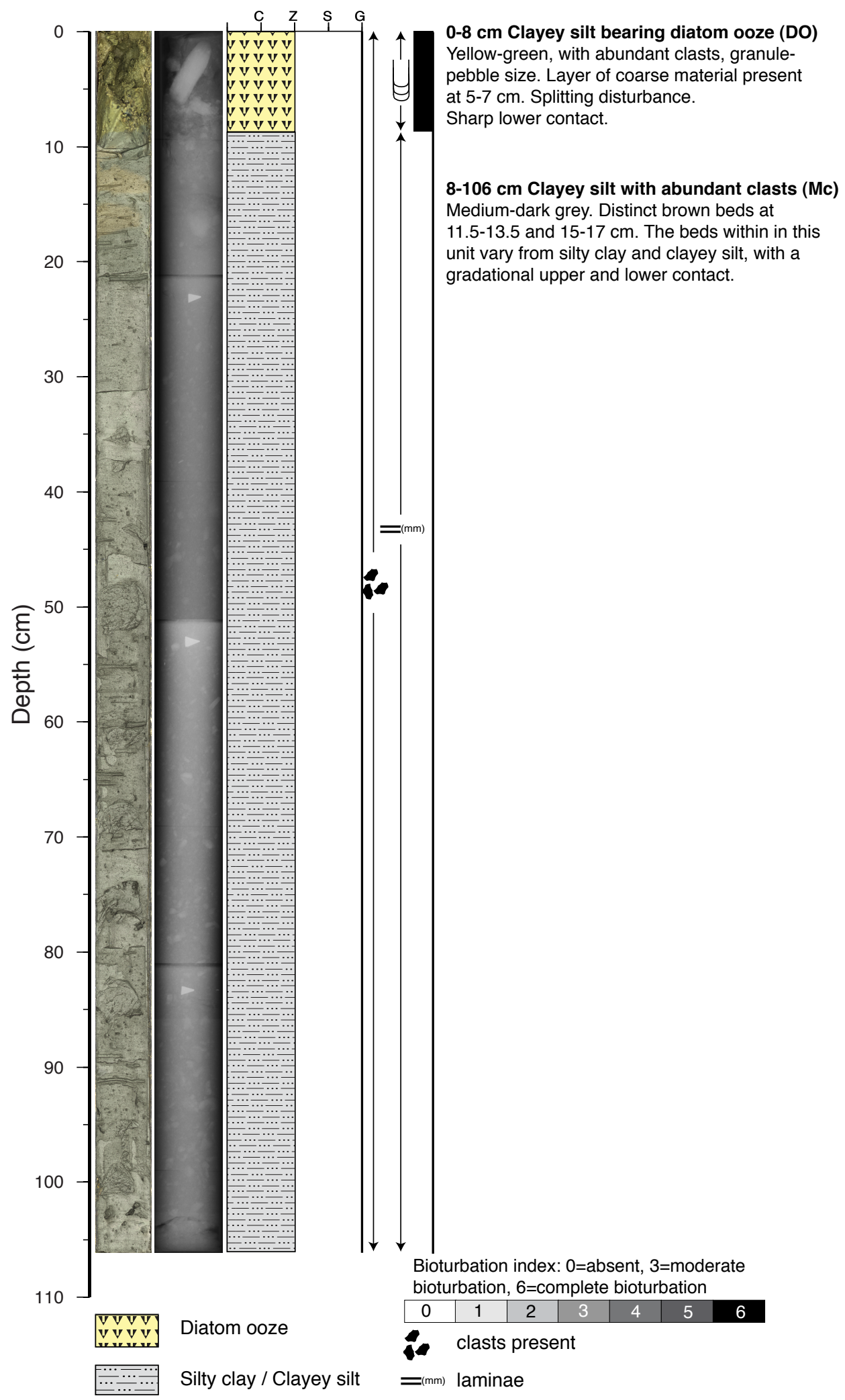

Figure B.5: Stratigraphic log for CHGC-17 


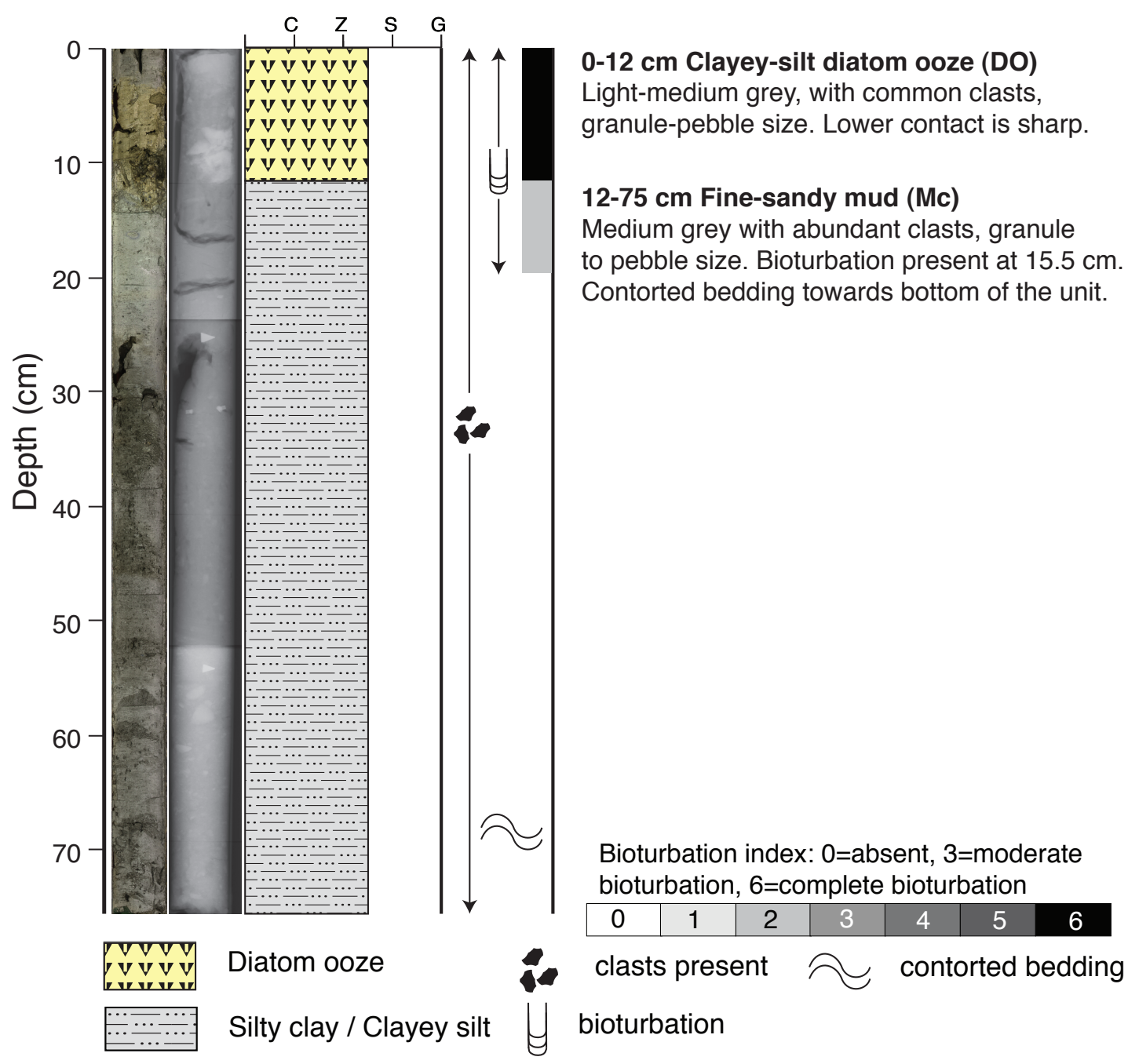

Figure B.6: Stratigraphic log for CHGC-22 


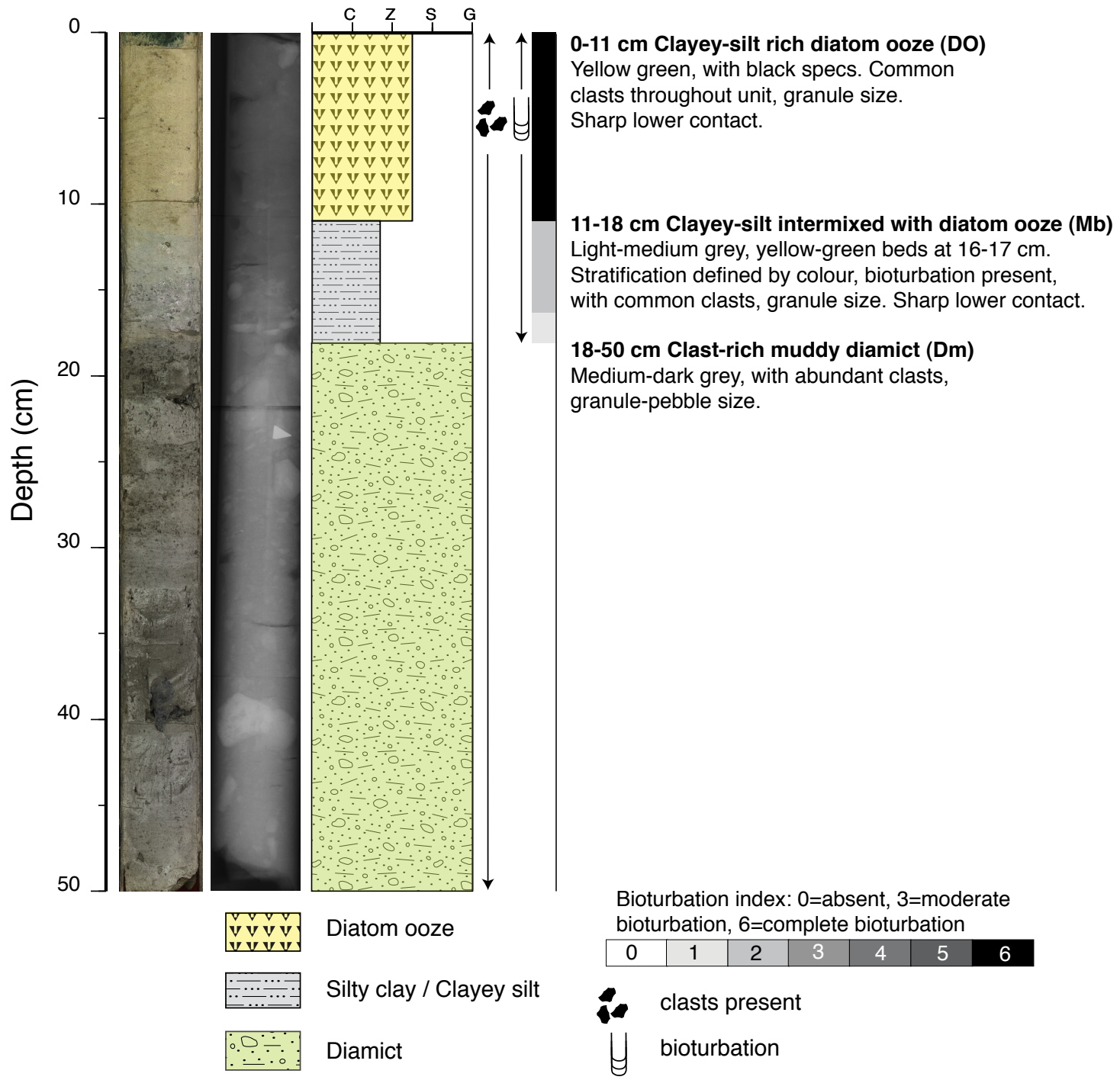

Figure B.7: Stratigraphic log for CHGC-23 


\section{Physical properties}

Data presenting the physical properties from the split cores.

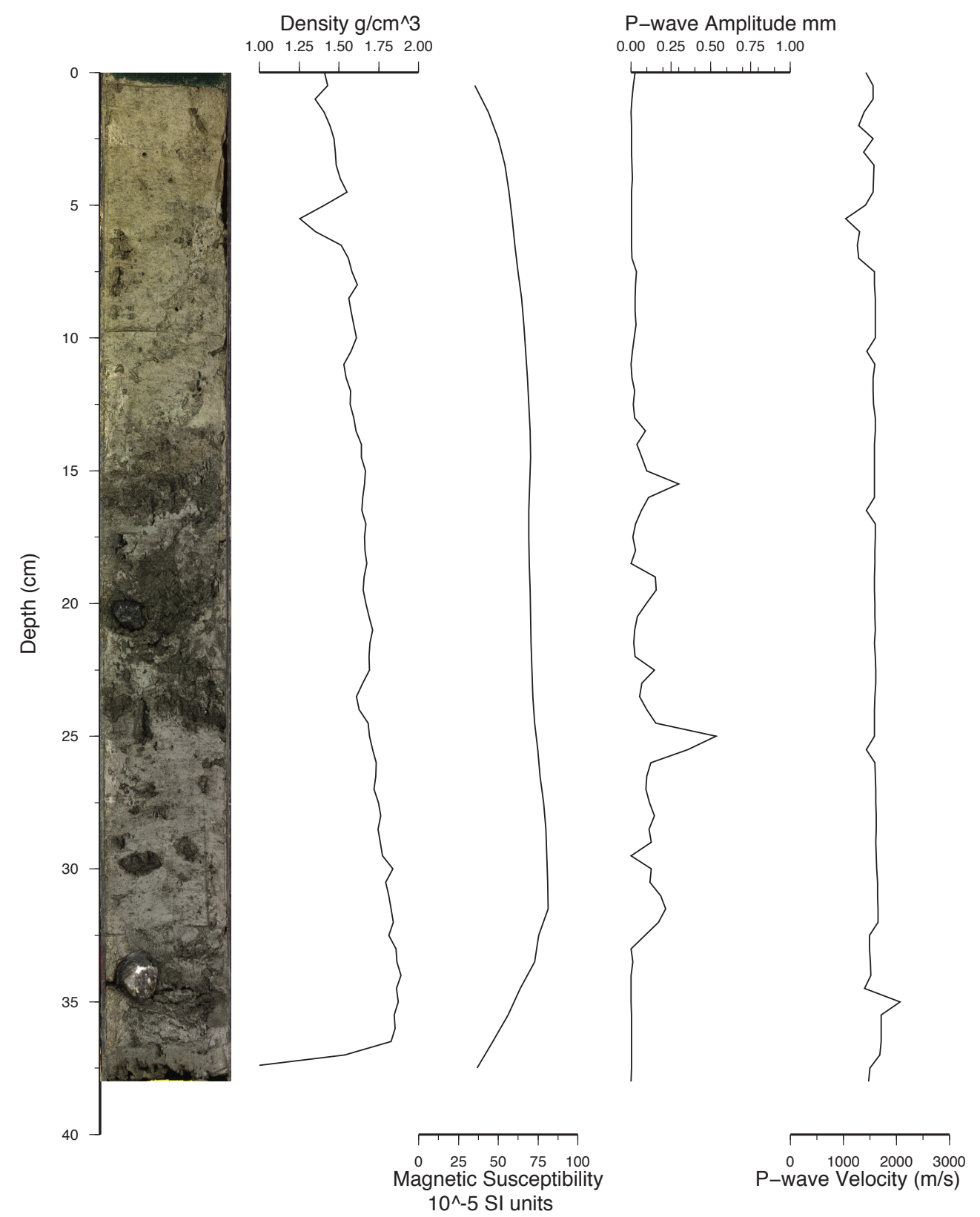

Figure B.8: Physical properties from CHGC-05. a) scanned image and x-ray of the core, b) density, c) magnetic susceptibility, d) p-wave amplitude, e) p-wave velocity. 


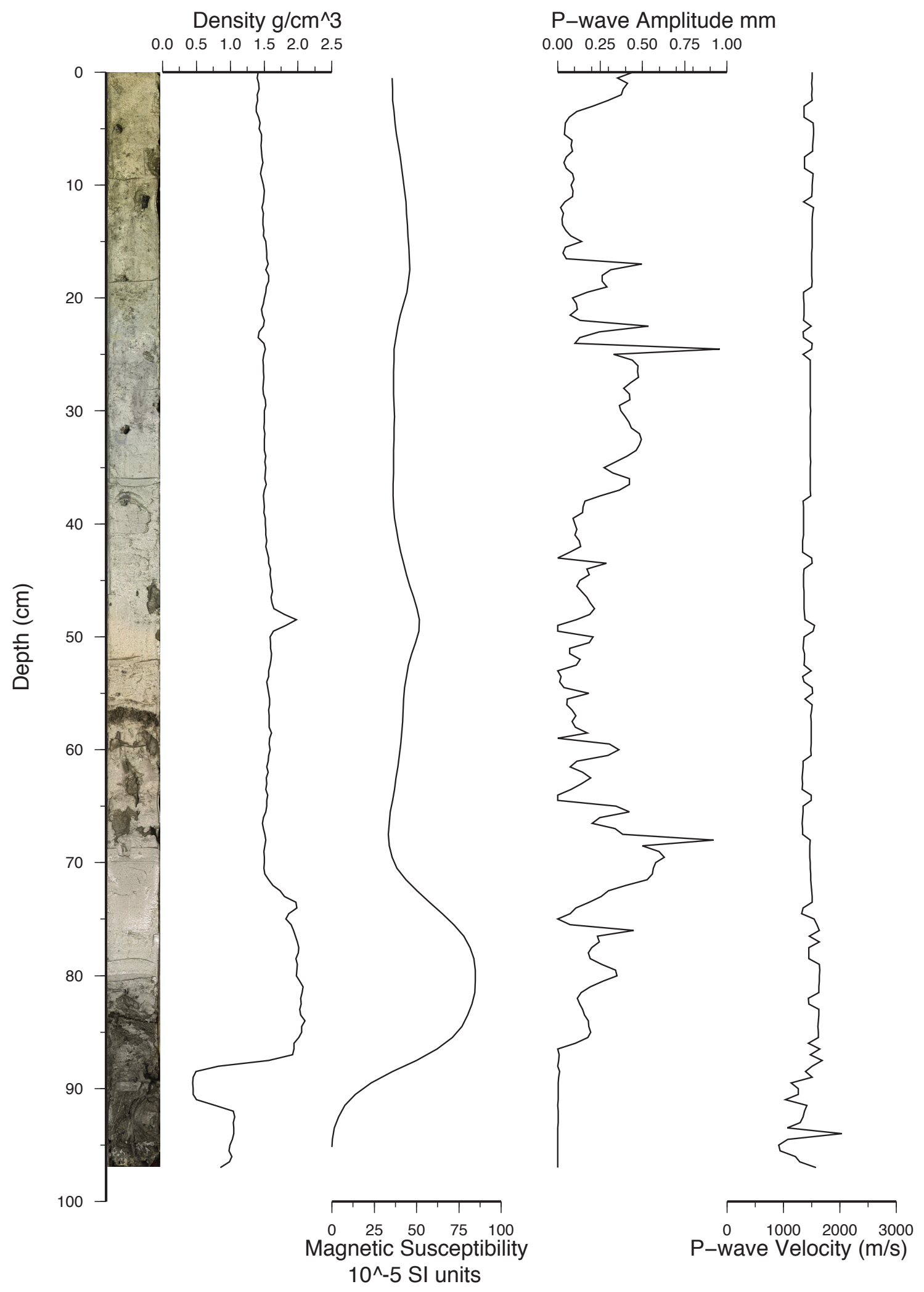

Figure B.9: Physical properties from CHGC-11. a) scanned image and x-ray of the core, b) density, c) magnetic susceptibility, d) p-wave amplitude, e) p-wave velocity. 


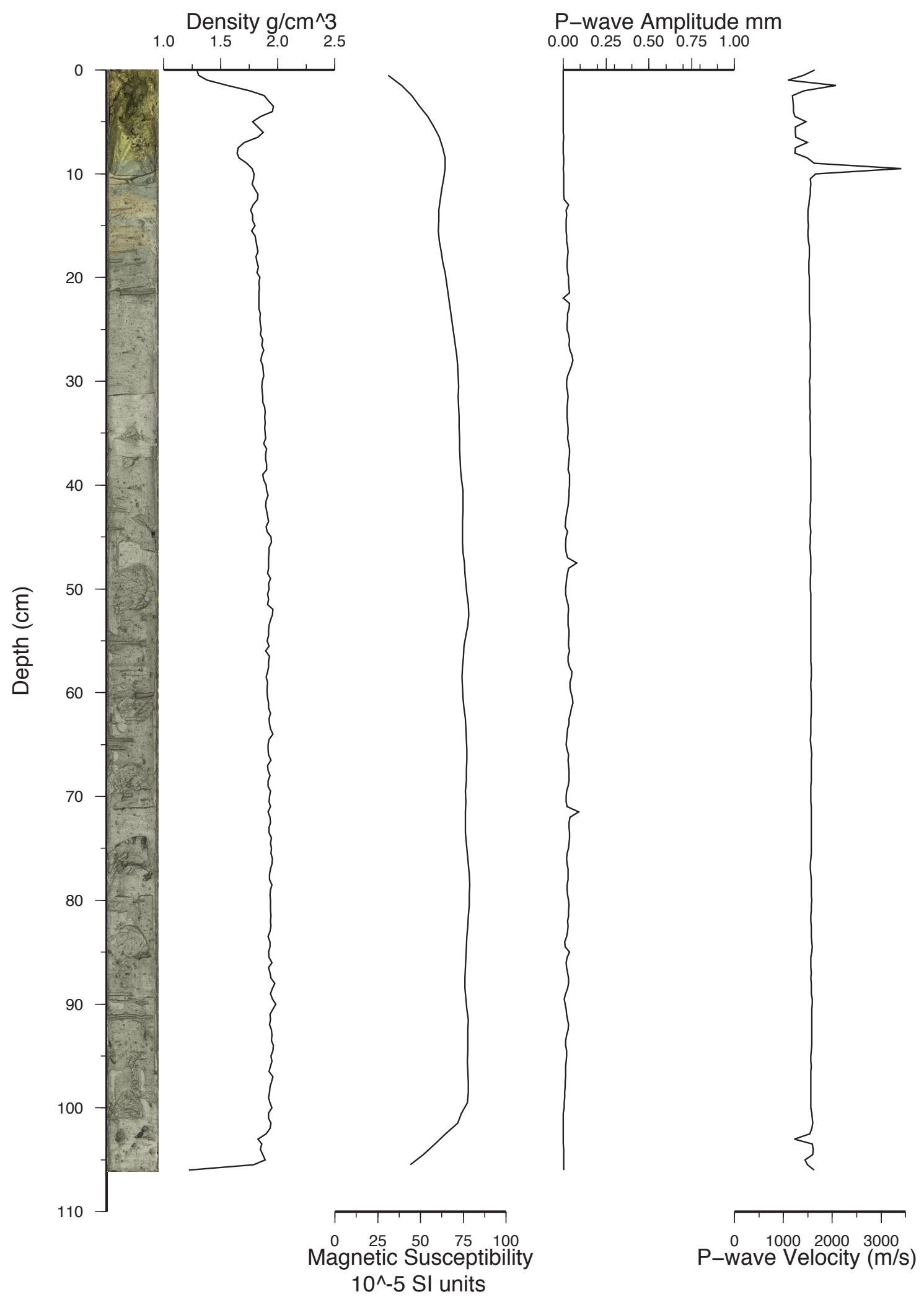

Figure B.10: Physical properties from CHGC-17. a) scanned image and x-ray of the core, b) density, c) magnetic susceptibility, d) p-wave amplitude, e) p-wave velocity. 


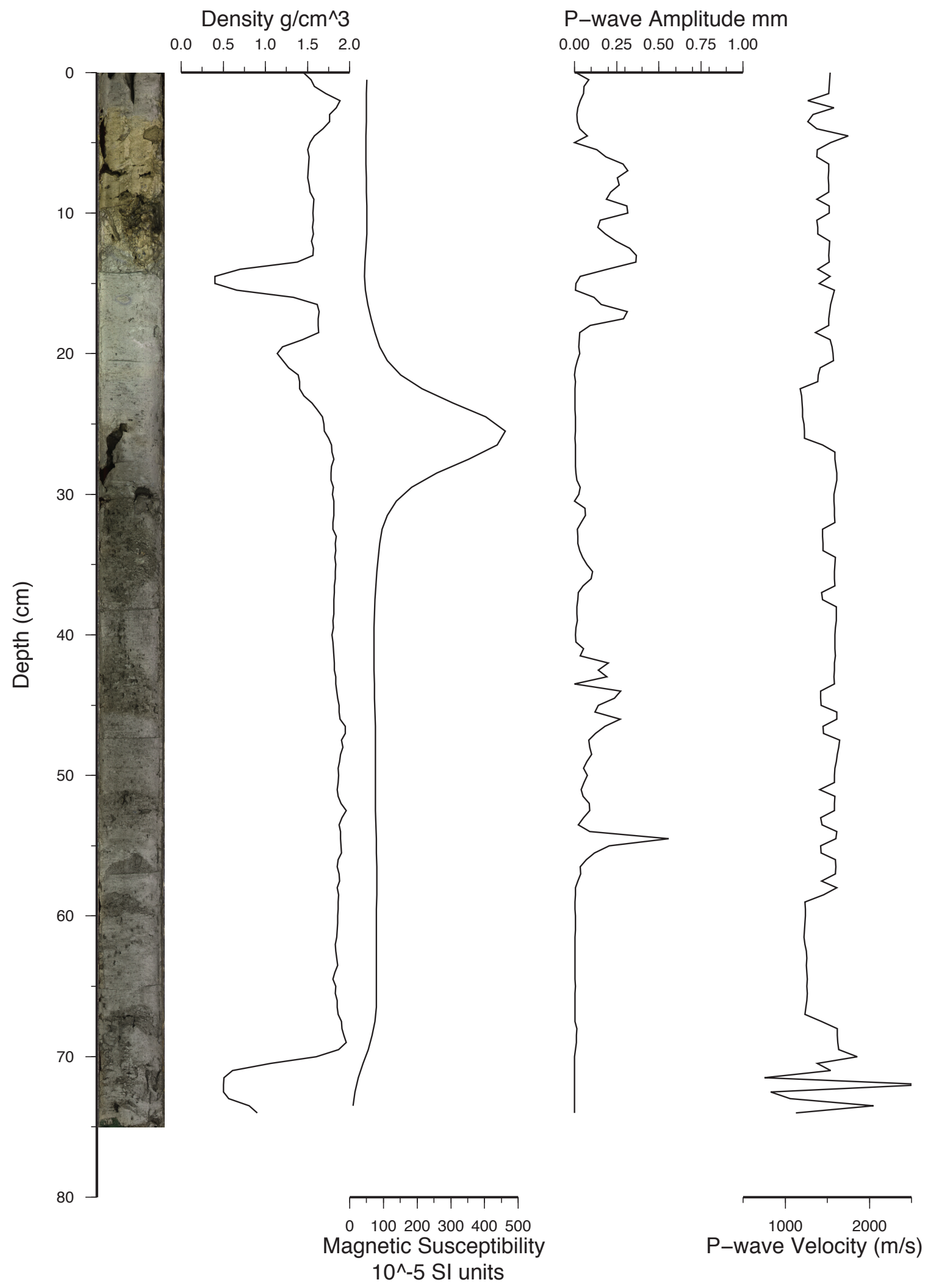

Figure B.11: Physical properties from CHGC-22. a) scanned image and x-ray of the core, b) density, c) magnetic susceptibility, d) p-wave amplitude, e) p-wave velocity. 


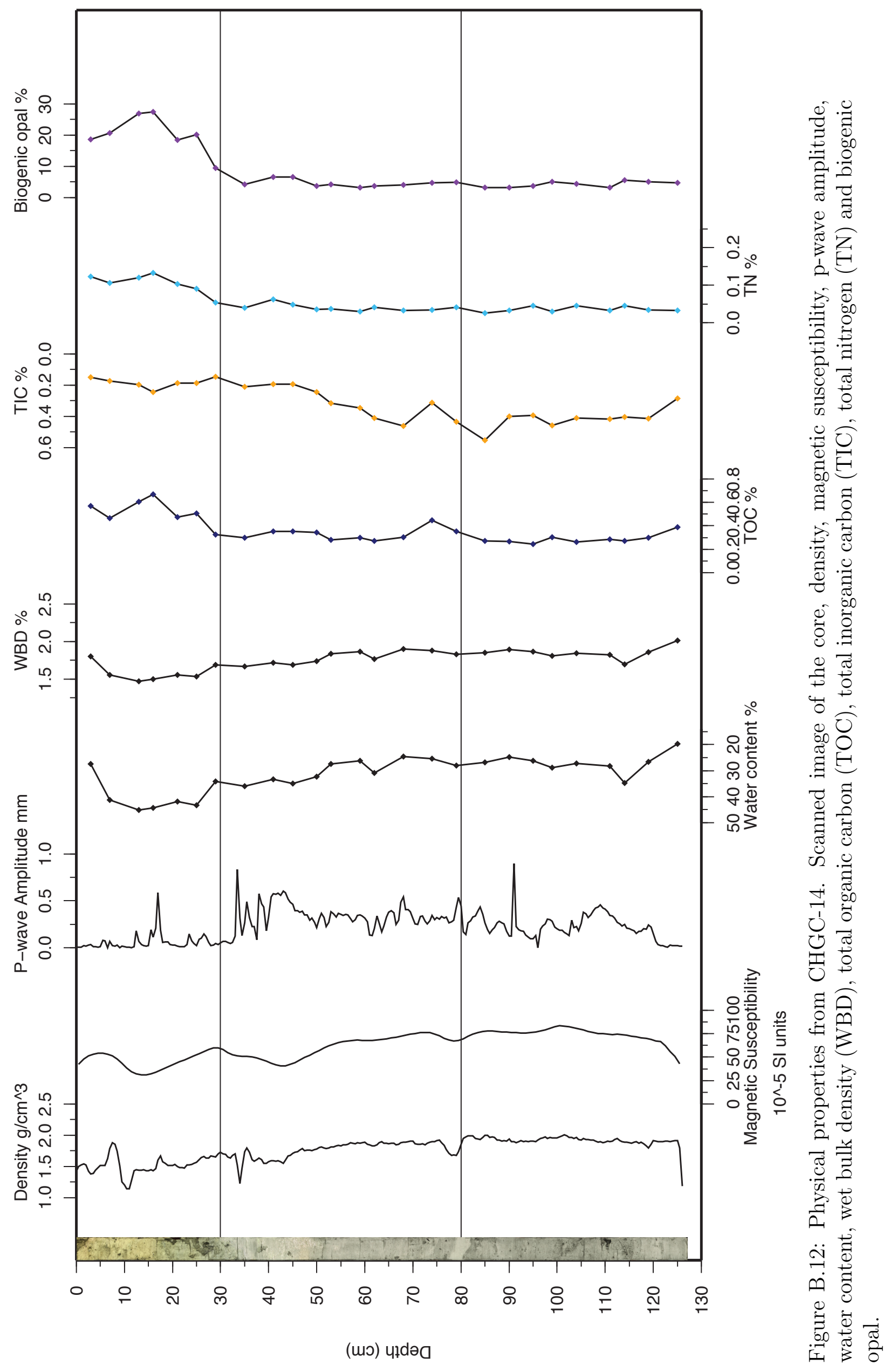




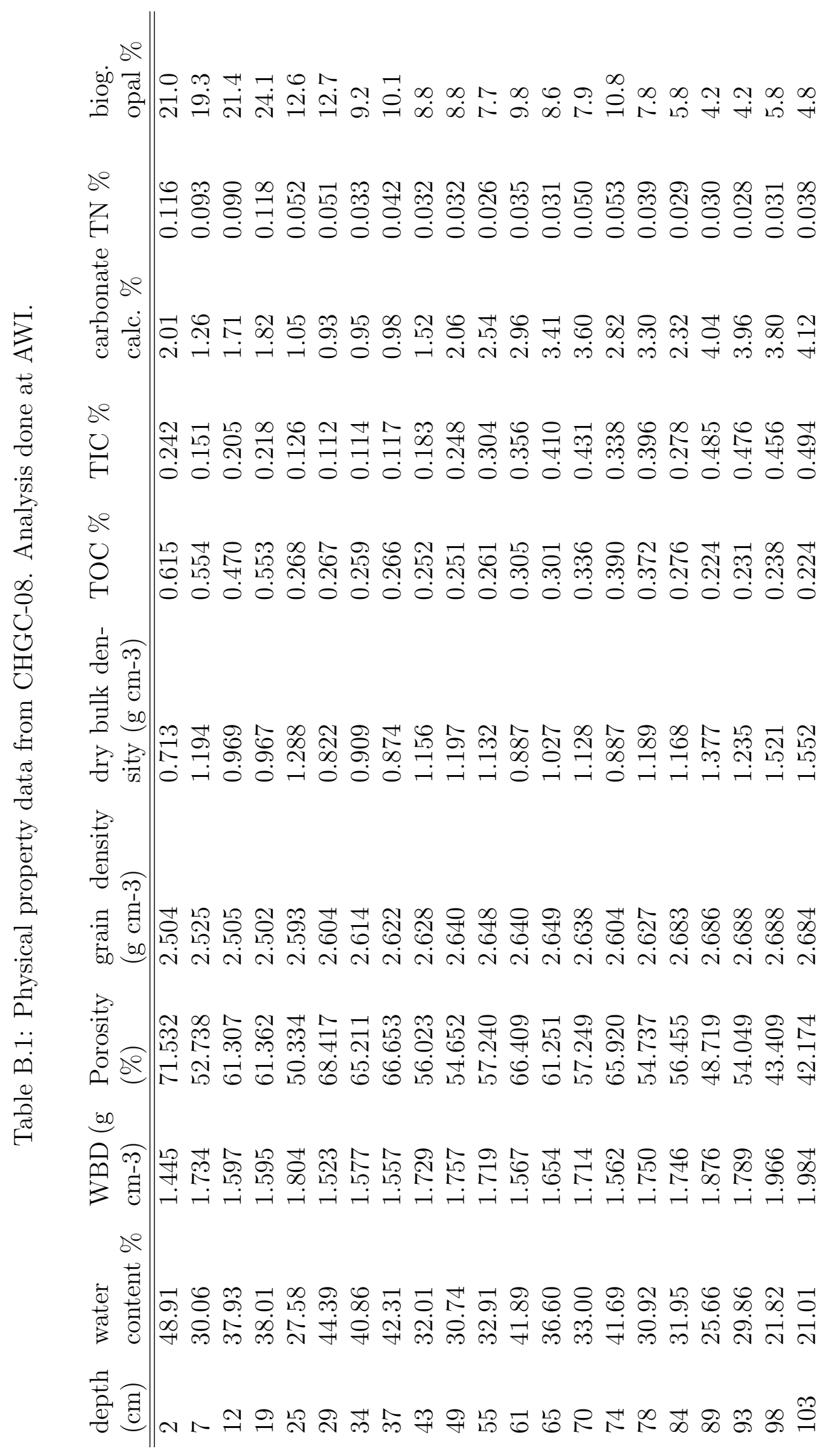




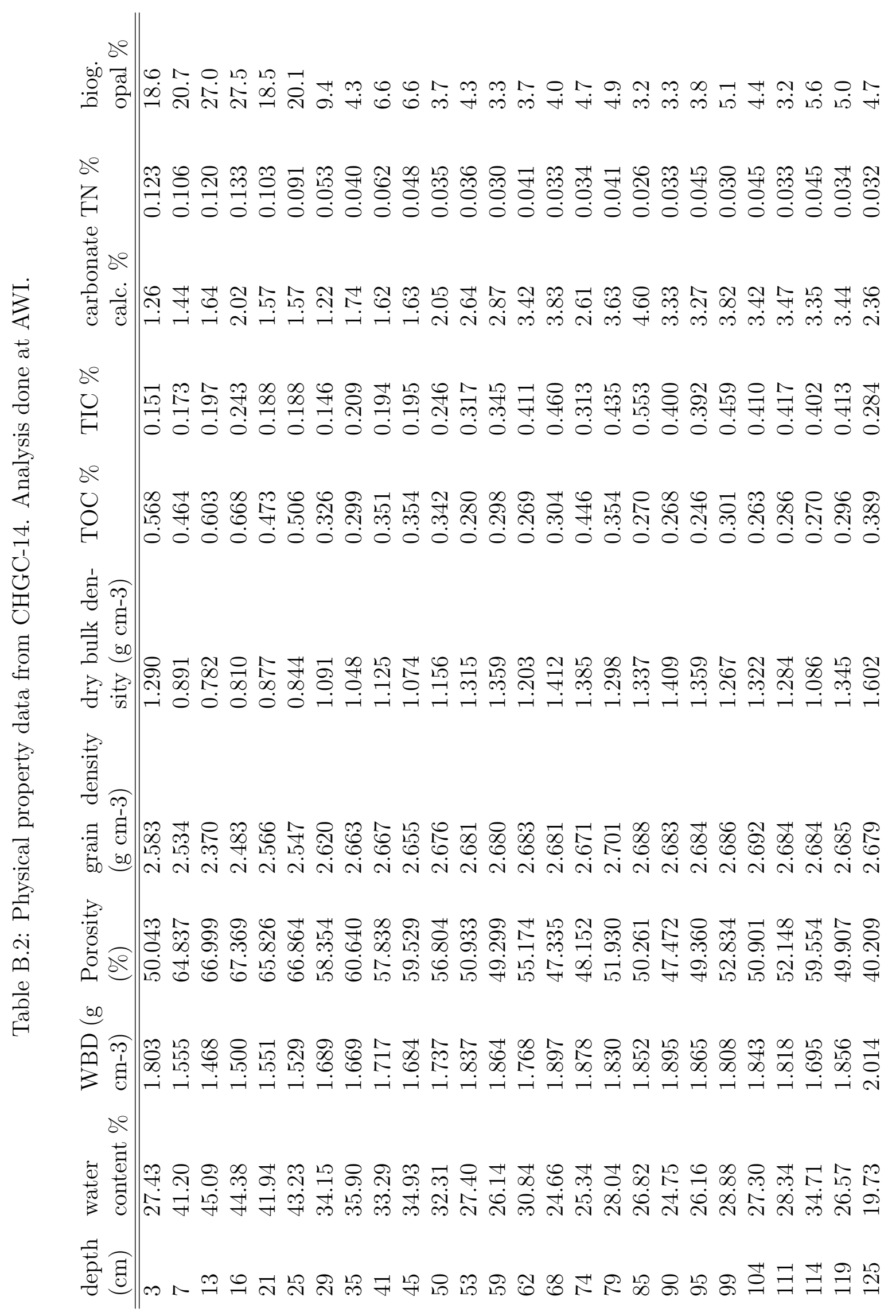




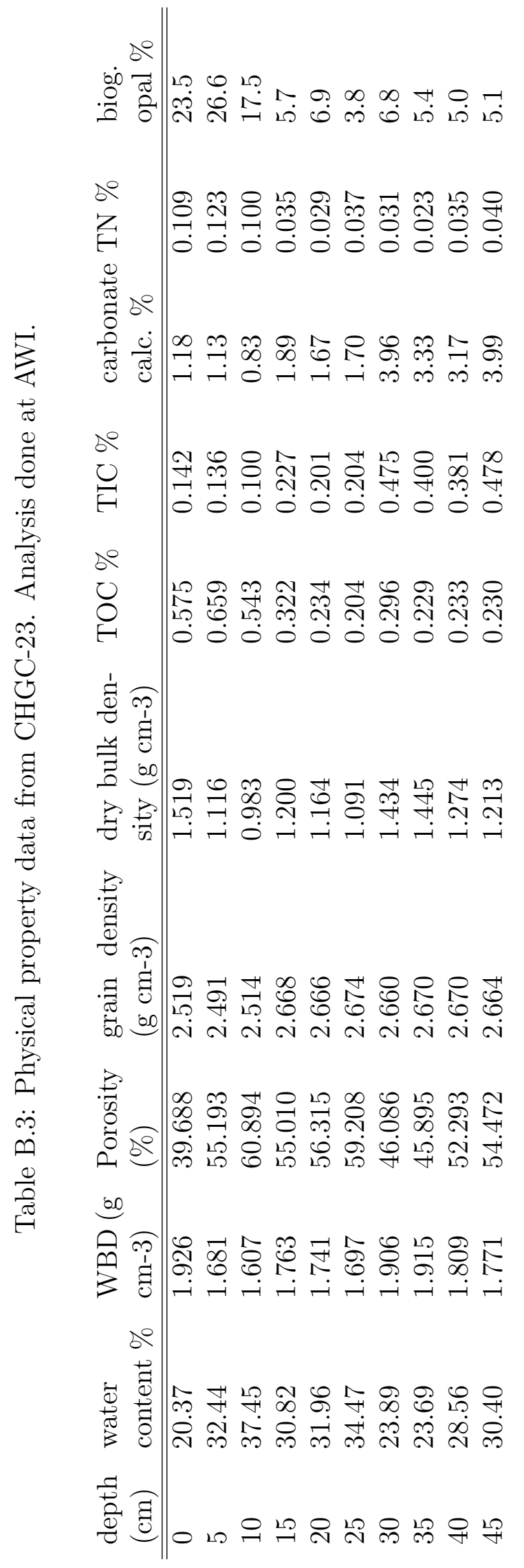


APPENDIX B. DATA FROM ALL CORES

Diatom content in CHGC-08

Table B.4: Diatom counts

\begin{tabular}{cc} 
Depth $(\mathrm{cm})$ & $* 10^{9}(\mathrm{v} / \mathrm{g})$ \\
\hline \hline 4 & 1.8242 \\
9 & 1.4623 \\
14 & 1.3672 \\
21 & 1.0692 \\
27 & 0.5793 \\
32 & 0.4559 \\
39 & 0.4288 \\
45 & 0.3736 \\
49 & 0.5097 \\
52 & 0.5868 \\
54 & 0.6125 \\
57 & 0.7450 \\
59 & 0.7417 \\
60 & 0.5402 \\
63 & 0.4911 \\
67 & 0.4628 \\
74 & 0.4685 \\
80 & 0.3936 \\
86 & 0.3683 \\
92 & 0.3263 \\
99 & 0.2920 \\
105 & 0.2715
\end{tabular}




\section{Grain size CHGC-08}

Grain size $>150 \mu \mathrm{m}$ on CHGC-08, Site 2.

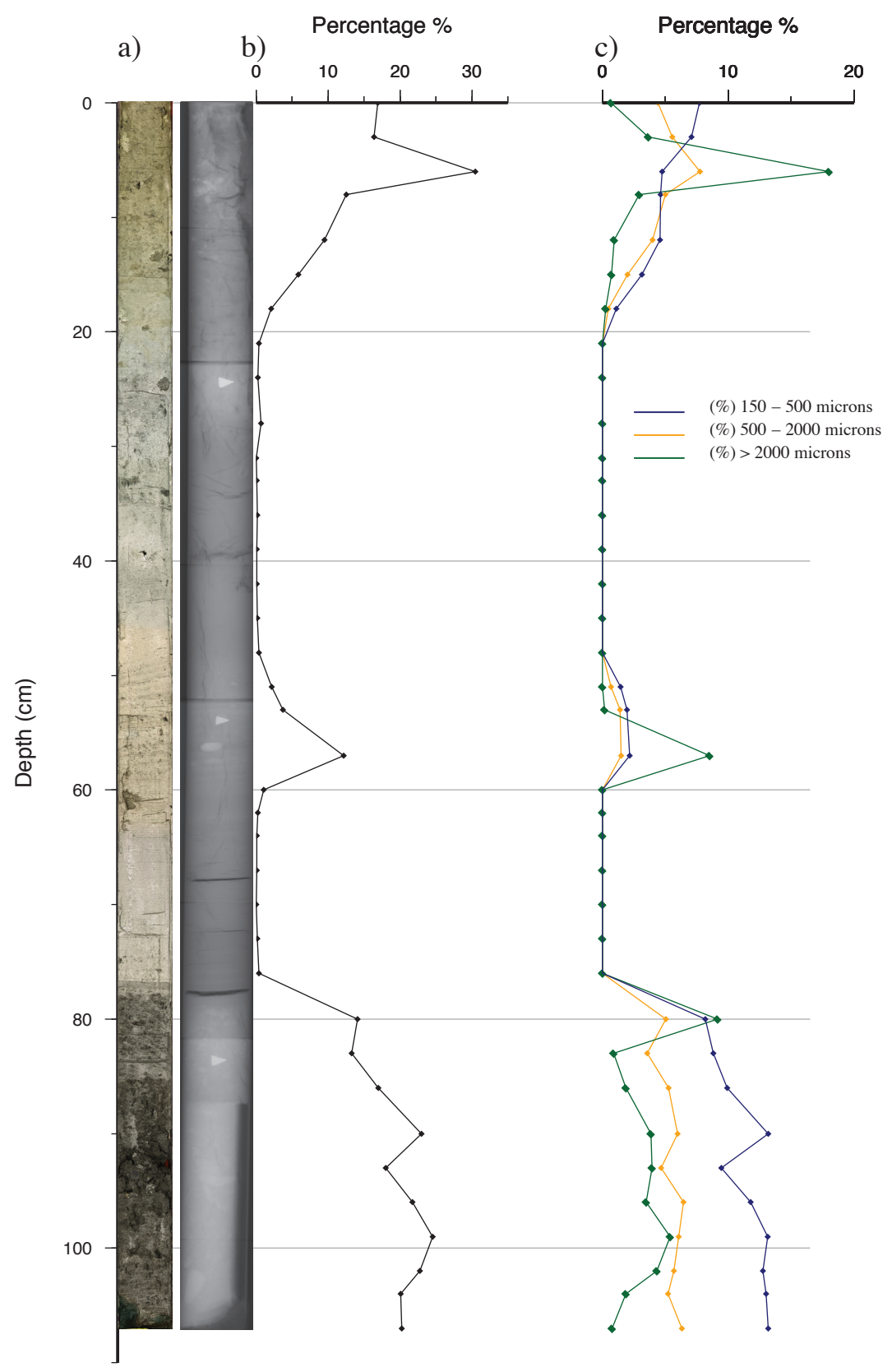

Figure B.13: Grainsize analysis on CHGC-08. a) weight percentage of grains greater than $150 \mu \mathrm{m}$. b) the greater than $150 \mu \mathrm{m}$ fraction divided in 150-500 $\mu \mathrm{m}, 500-2000$ $\mu \mathrm{m}$ and greater than $2000 \mu \mathrm{m}$. 
Grainsize analysis done on CHGC-08, Site 2.

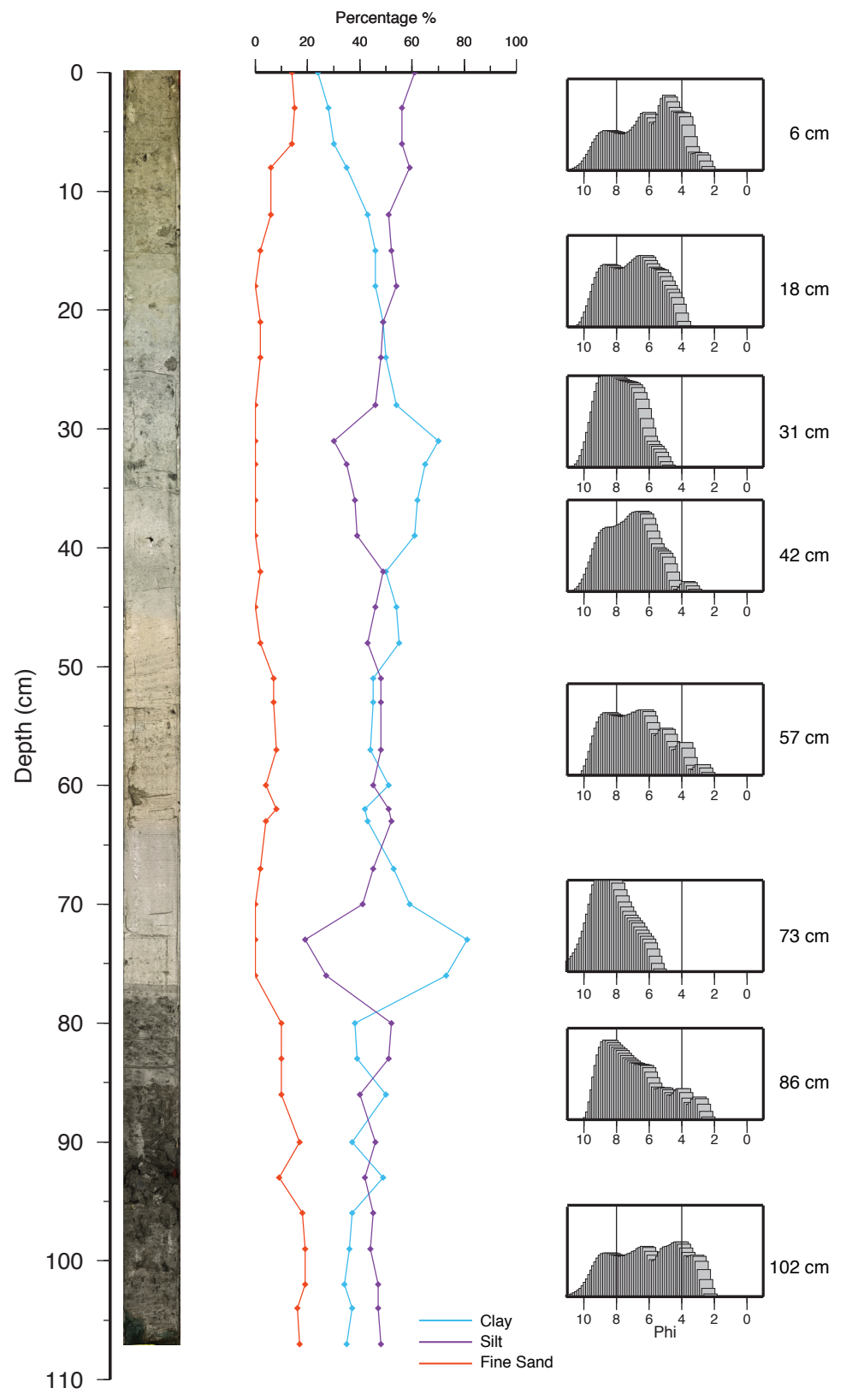

Figure B.14: Grainsize analysis on CHGC-08, smaller than $150 \mu \mathrm{m}$. The image of the core, the clay, silt and fine sand percentage throughout the core, and individual histograms at particular depths with a division line between clay/silt ( 8 phi), and silt/fine sand (4 phi). 


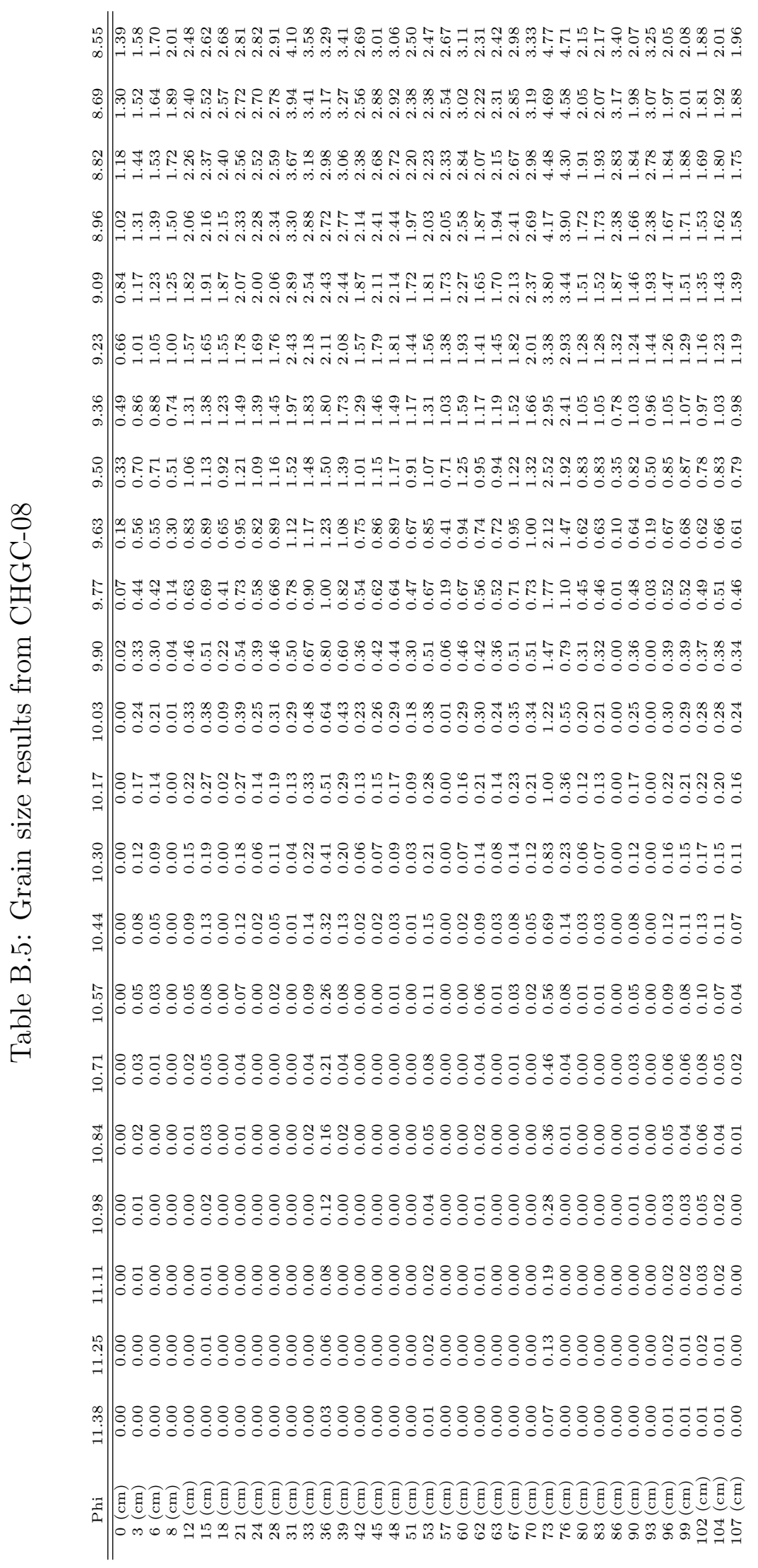




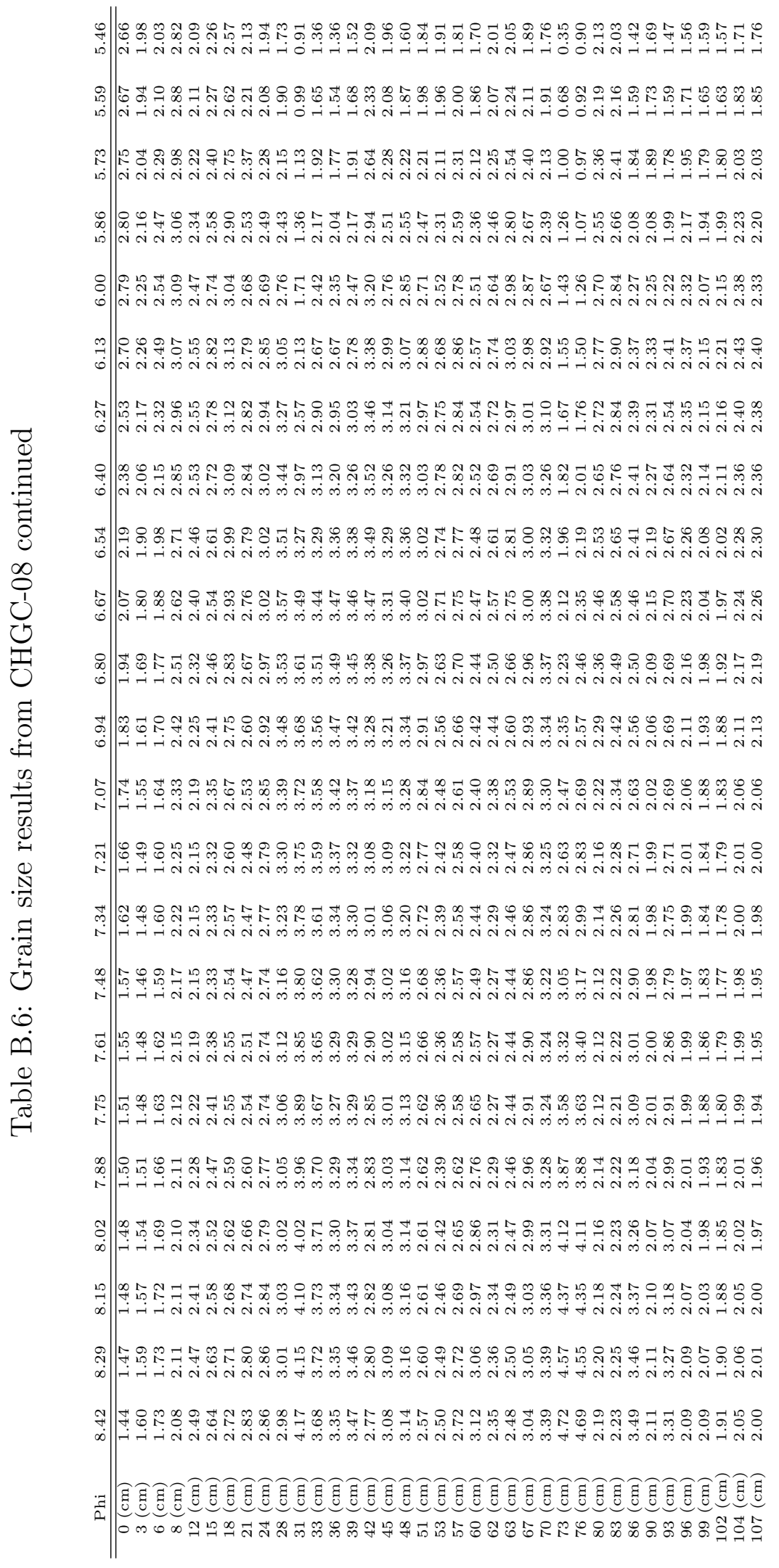




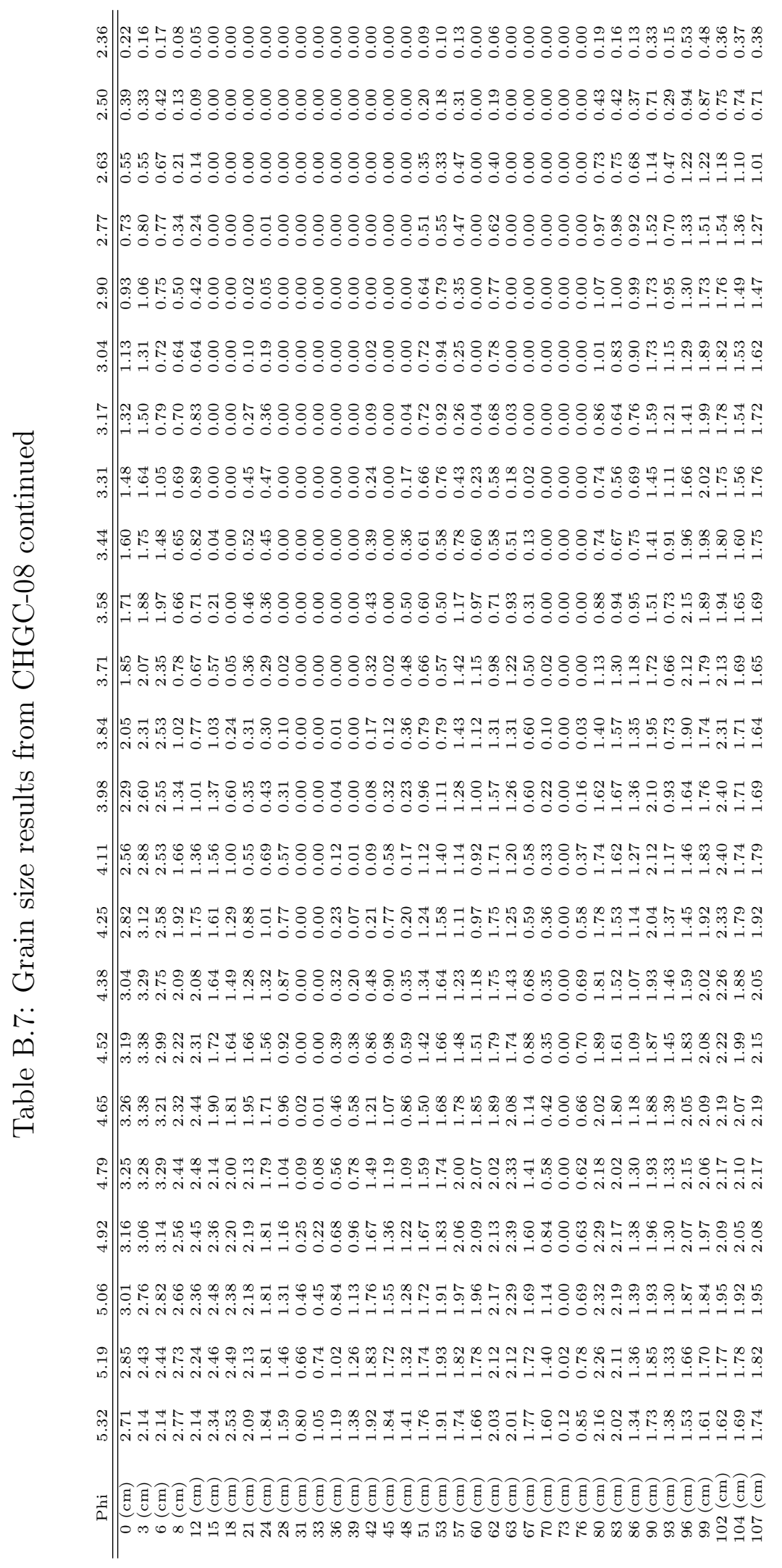




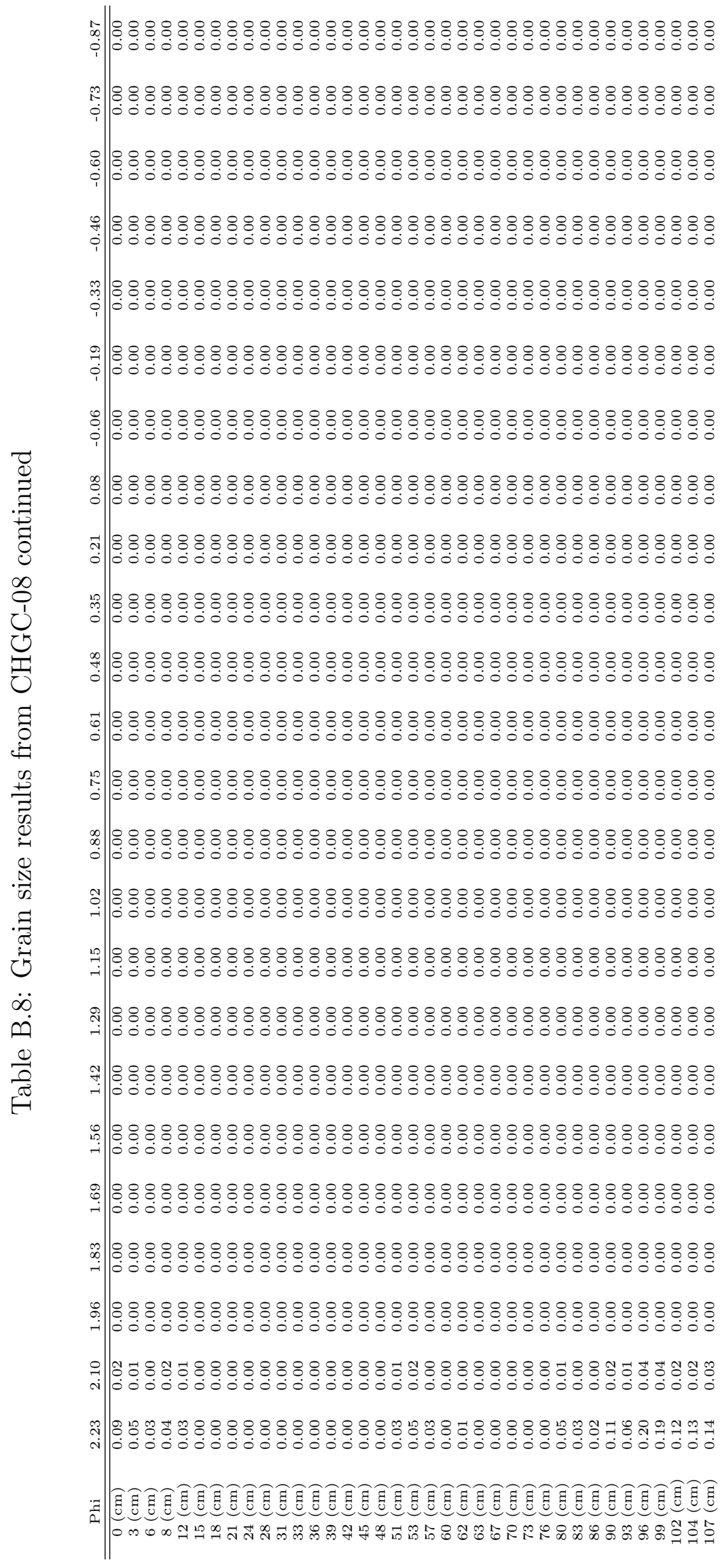




\section{Petrology Count}

Table B.9: Petrology counts for CHGC-08

\begin{tabular}{r|cccccccc} 
& $90 \mathrm{~cm}$ & $80 \mathrm{~cm}$ & $57 \mathrm{~cm}$ & $53 \mathrm{~cm}$ & $51 \mathrm{~cm}$ & $8 \mathrm{~cm}$ & $3 \mathrm{~cm}$ & $1 \mathrm{~cm}$ \\
\hline \hline Heavy minerals & 3 & 9 & 4 & 4 & 1 & 2 & 2 & 9 \\
Calcite rock & 7 & 0 & 2 & 0 & 0 & 0 & 0 & 0 \\
Calcite min & 4 & 2 & 0 & 7 & 0 & 0 & 0 & 0 \\
Marble & 0 & 3 & 1 & 0 & 1 & 0 & 0 & 0 \\
Basalt & 6 & 0 & 1 & 0 & 2 & 1 & 3 & 1 \\
Dolerite & 5 & 7 & 1 & 3 & 2 & 2 & 2 & 1 \\
Feldspar & 19 & 6 & 7 & 1 & 7 & 32 & 33 & 25 \\
Quartz & 43 & 47 & 36 & 34 & 22 & 25 & 56 & 43 \\
Round quartz & 8 & 7 & 17 & 10 & 2 & 4 & 2 & 5 \\
Mica & 1 & 1 & 1 & 0 & 0 & 1 & 0 & 3 \\
Mylonitic granite & 2 & 16 & 5 & 12 & 13 & 4 & 5 & 14 \\
Granite & 27 & 17 & 1 & 12 & 8 & 15 & 22 & 22 \\
Polygranular quartz & 6 & 1 & 2 & 1 & 8 & 3 & 6 & 1 \\
Sandstone & 8 & 0 & 0 & 0 & 0 & 1 & 0 & 1 \\
Metasedimentary & 12 & 7 & 6 & 6 & 3 & 0 & 2 & 3 \\
Metamorphic & 8 & 3 & 4 & 2 & 2 & 0 & 5 & 0 \\
Phyllite & 1 & 2 & 1 & 0 & 1 & 0 & 0 & 0 \\
Biotite schist & 3 & 10 & 0 & 0 & 0 & 0 & 0 & 0 \\
Diamict & 18 & 11 & 17 & 3 & 5 & 0 & 0 & 0 \\
Carbonate & 0 & 1 & 0 & 1 & 1 & 0 & 0 & 0
\end{tabular}

\section{Sortable silt}

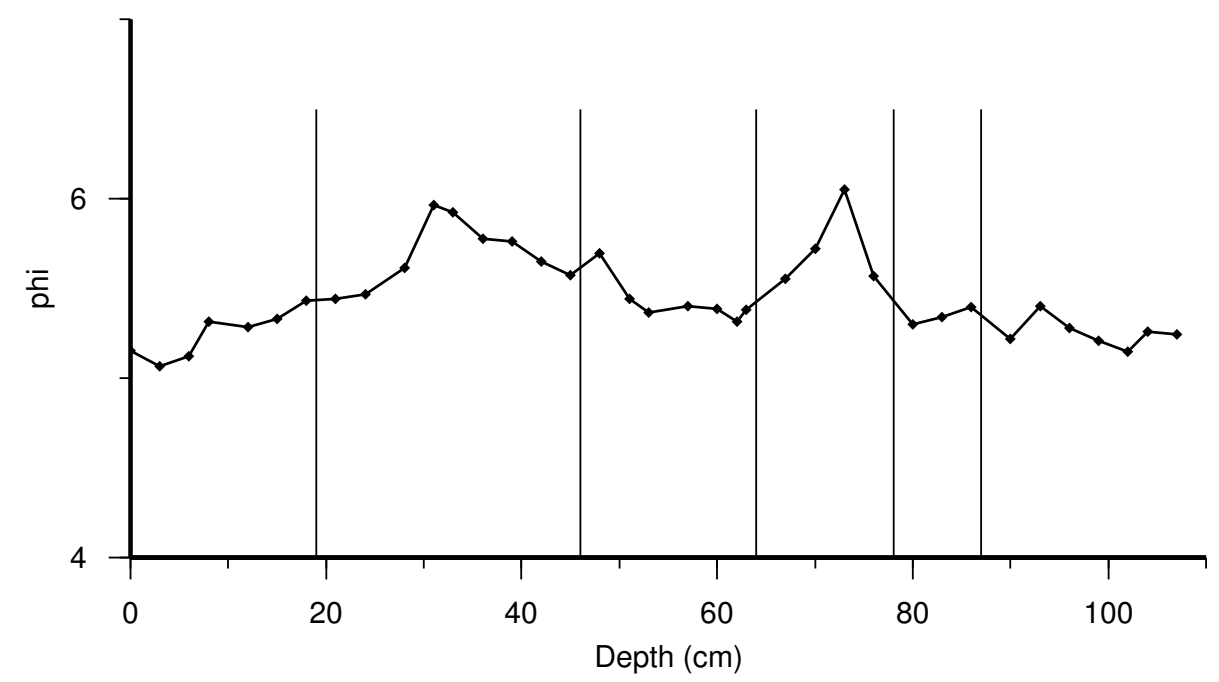

Figure B.15: Sortable silt data from CHGC-08. 